\title{
Communication skills : teaching, testing and learning
}

Citation for published version (APA):

van Dalen, J. (2001). Communication skills : teaching, testing and learning. [Doctoral Thesis, Maastricht University]. Datawyse / Universitaire Pers Maastricht. https://doi.org/10.26481/dis.20010927jd

Document status and date:

Published: 01/01/2001

DOI:

10.26481/dis.20010927jd

Document Version:

Publisher's PDF, also known as Version of record

\section{Please check the document version of this publication:}

- A submitted manuscript is the version of the article upon submission and before peer-review. There can be important differences between the submitted version and the official published version of record.

People interested in the research are advised to contact the author for the final version of the publication, or visit the DOI to the publisher's website.

- The final author version and the galley proof are versions of the publication after peer review.

- The final published version features the final layout of the paper including the volume, issue and page numbers.

Link to publication

\footnotetext{
General rights rights.

- You may freely distribute the URL identifying the publication in the public portal. please follow below link for the End User Agreement:

www.umlib.nl/taverne-license

Take down policy

If you believe that this document breaches copyright please contact us at:

repository@maastrichtuniversity.nl

providing details and we will investigate your claim.
}

Copyright and moral rights for the publications made accessible in the public portal are retained by the authors and/or other copyright owners and it is a condition of accessing publications that users recognise and abide by the legal requirements associated with these

- Users may download and print one copy of any publication from the public portal for the purpose of private study or research.

- You may not further distribute the material or use it for any profit-making activity or commercial gain

If the publication is distributed under the terms of Article $25 \mathrm{fa}$ of the Dutch Copyright Act, indicated by the "Taverne" license above, 
COMMUNICATION SKILls 
Cover photo Snowdon. Igor Surawinski. My Life in Pictures

Cover design Datawyse Maastricht

Printing Datawyse / Universitaire Pers Maastricht

ISBN 9052783195

(6) Taylor \& Francis Ldd. Chapters 1 and 2

6 Kluwer Academic Publishers, Chapters 3 and 6

Blackwell Science Lid. Chapter 5

Jan van Dalen, Other chapters 


\section{COMMUNICATION SKILLS TEACHING, TESTING AND LEARNING}

\section{PROEFSCHRIFT}

ter verkrijging van de graad van doctor aan de Universiteit Maastricht, op gezag van de Rector Magnificus,

Prof. dr. A.C. Nieuwenhuijzen Kruseman

volgens het besluit van het College van Decanen, in het openbaar te verdedigen

op donderdag 27 september 2001 om 16.00 uur

door

Jan van Dalen

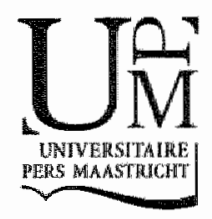




\section{Promotores}

Prof. dr. C.P.M. van der Vleuten

Prof. dr. A.J.J.A. Scherpbier

Beoordelingscommissie

Prof, dr. J.J.C.B. Bremer (Voorzitter)

Dr. R. van Diest

Prof. dr. J.C.J.M. de Haes (Universiteit van Amsterdam)

Prof. dr. S.M. Kurtz (University of Calgary)

Dr. P. Ram

SkillsMeducation provided financial support of this dissertation. 
Paranimfen

Ellen Kerkhofs

Bertha van Knippenberg-van den Berg 


\section{Contents}

Voorwoord

Preface

Introduction

1. Teaching and assessing communication skills in Maastricht Medical Teacher $2001: 23: 245-51$.

2. Factors influencing the effectiveness of communication skills training. Medical Teacher 1999:21:308-10.

3. Construct validity of the MAAS-Global

Advances in Heallu Sciences Education 1998;3:187-95.

4. Integrated assessment of communication skills Submitted

5. Predicting communication skills with a paper-and-pencil test Accepted for publication, Medical Education

6. Longitudinal and concentrated communication skills programmes compared Advances in Health Sciences Education, in press

7. Development of communication skills in the medical curriculum Submitted

Conclusions and discussion

Summary

Samenvatting

Curriculum vitae 


\section{Voorwoord}

$T^{i j d e n s ~ h e t ~ G e z o n d ~ O n d e r w i j s ~ C o n g r e s-8 ~ i n ~ n o v e m b e r ~} 1998$ hadden Bertha van Knippenberg-van den Berg en ik onze eerste gedachtewisseling over de mogelijke samenwerking, die zou leiden tot de bevindingen waarover in dit proefschrift verslag wordt gedaan. Dat was precies 20 jaar nadat ik bij het Skillslab was komen werken.

Het is geen oorspronkelijke gedachte, maar een proefschrift is het resultaat van een samenwerking waarvoor slechts één de lof krijgt. $\mathbb{~} \mathrm{k}$ ben veel mensen dank verschuldigd.

Mijn ouders staan bovenaan in mijn dankwoord, alleen al omdat ze me hebben laten studeren. Ze hebben mijn keuzes altijd gerespecteerd. Bovendien hebben ze me een talent helpen ontwikkelen waar ik erg blij mee ben: het vermogen om te genieten. Daarnaast heb ik veel geleerd in het omgaan met mijn zoons, Arjen en Thijs. Zij hielden me altijd wel met mijn voeten op de grond als ik bezig was 'de wetenschap te bedrijven'.

Een van de belangrijkste dingen die ik met dit onderzoek geleerd heb is dat er zoveel mensen meeleven en bereid zijn zich in te zetten. Bijvoorbeeld: de ongeveer 50 observatoren die $i k$ benaderd heb om gezamenlijk een paar keer een dag naar Leiden te gaan reageerden binnen een week op mijn e-mail, de meesten positief en allemaal constructief. Ik wil dat zij allen weten dat ik hen dankbaar ben.

Zelfs binnen die welwillende omgeving zijn sommigen meer gelijk dan anderen, en hen wil ik hier noemen.

Om mee te beginnen, mijn promotoren: Cees van der Vleuten en Albert Scherpbier. Jullie, heren, zijn ware professoren, in vele opzichten. In het bijzonder vanwege jullie kennis van medisch onderwijs, jullie wijsheid, wetenschappelijke precisie, voortdurende steun en continue hoge tempo zijn jullie in mijn ogen de beste supervisoren die iemand zich kan wensen. Op de meeste concept artikelen kreeg ik binnen twee dagen specifiek, concreet commentaar, met suggesties hoe ik onduidelijkheden in mijn tekst kon ophelderen. Alleen hiervoor al verdienen jullie, met 
Ellen, mijn eervolle vermelding: ACE of supervision. De voortdurende aanmoediging en lol deden de rest. Ik sta bij jullie in het krijt.

Bij het maken van de kennis-over-communicatie-vaardigheden toets ben ik geinspireerd door Lambert Schuwirth en verder geholpen door de welwillende nauvgezetheid van Marten Verwijnen. Jam-Joost Rethans heeft in zijn eentje het nagenoeg gehale vierde jaar geneeskunde studenten in Maastricht gemotiveerd aan deze toets mee te doen.

Dank voor het commentaar op de vragen voor de Respecivolle Bejegening Schaal gaat naar Susan Bögels, Hanneke Hamers, Paul Ram, Albert Scherpbier, Jacques. van Thel en Cees van der Vleuten. Margriet Brorens and Desirée Bromkers hielpen de afname van deze schaal te verwezenliken en Guus Smeets en Ron Hoogenboom hielpen bij de statistische bewerkingen met dit instrument.

De casus voor de stationstoets zijn mede gemaakt door de volgende dokters: Marjo Boumans, Jolanda Land, Jeroen Koomans en Jan-Joost Rethans. Giel Peeters, Rob Schonck en Jos op "t Root stonden toe dat ik inbrak in het co-assistentschap Huisartsgeneeskunde. Kiki Nittel en Meline den Heyer van de afdeling Gynaecologie en Obstetrie van het Leids Universitair Medisch Centrum maakten tijd vrij in hun trainingprogramma.

Paul Ram, Jacques van Thiel en Cees van der Vleuten lieten me hun video-apparatuur gebruiken, dic Michiel Jans ook nog hielp installeren.

Deze onderneming was niet mogelijk geweest zonder de 1414 deelnemende studenten.

Ik ben daarnaast de observatoren uit Maastricht en uit Leiden erkentelijk: Loes van Bokhoven, Marjo Boumans, Chantal Caes, Ingrid Candel, Diana Dolmans, Saskia van Es. Marie-Jeanine Haack. Marie-Anne Haenen, Beppie Hellemons. Marlies Huitema, Lidewij Janswedel. Helen Koch, Marie Jeanne Kooiman, Susanne Niemantsvendriet, Marijke Perquin. Myriam de Ruyter, Marjolein de Vries, Ineke Wolthagen. Pie Bartholomeus, Niels Chawannes, Rob van Diest, Paul Falger, Milchiel Jans, Bart Leunissen, Parrick wan Limpt, Rutger Lulofs, Albert Scherpbier en Marten Verwijnen.

Simulatie patienten wit Maastricht en uit Leiden reisden enthousiast naar het andere eind van het land: mw. M. Aelterman, nw. J. Ammeraal, mw. A.J. Beekman, mw. A. Buckinx, mw. K. van Hamsvoort, mw. A. Hintzen, mw. J. Kerbusch, mw. M. Lucassen, mw. H.A.M. Rijkelijkhuizen, dhr, N. Heuts, dhr. W. Huveneers, dhr. F. Martens, dhr. Th. Rommens, dhr. V. Schoonderwalt, dhr. J.J. Schrumpf, dhr. J.
Tillie en dhr. W. Winten.

Er stonden nogal wat medeauteurs en anderen in de vuurlinie van mijn verzoeken om commentaar op concept artikelen, ik dank jullie allen!

Pie Bartholomeus heeft me, in alle jaren die we in het Skillslab delen gesteund;
me Pie! 
Geke Blok, Geke, didn't we almost have it all?' We hebben onze ingewikkelde geschiedenis. Ik dank je voor veel, bijvoorbeeld voor onze pogingen tot onderzoek van onderwijs, ooit verhelderd door een gezamenlijke collega als: "meten wat niet gemeten kan worden". ?

Katinka Prince, ik koester onze vriendschap, met je voortdurende betrokkenheid, enthousiasme, steun en pret.

Dames van het toenmalige Skillslab-secretariat, ik dank jullie voor je organisatorische werk (de brieven, de inschrijvingen voor experimenten, rampen-opvang, en de feedback aan studenten): Juliana Been, Esther Colberts, Marleen van Zandvoort en in het bijzonder mijn hartsvriendin, de onvervangbare Rina Herpers-Gibbels. Rina, dank je ook dat je me helpt een beetje stabiel te blijven!

Ik dacht dat ik goed Engels schreef totdat mijn eerste concept antikel van Mereke Gorsira terugkwam. Toen bleek me pas hoe mijn tekst in echt Engels er uitziet. Voor je enorme vaardigheid in het Engels en Nederlands, en voor je vriendschap: dank je wel, Mereke.

De sfeer van wederzijdse steun in het Skillslab wordt gemaakt door mijn collega's van de Skillslab staf: dank jullie allemaal. Ik ben er trots op hier te werken.

Ieta van den Hout, ik ben je erkentelijk voor je enthousiasme, voor alle ideeën en voor de steun die je steeds hebt gegeven.

Onmisbaar voor het succes van de samenwerking tussen Leiden en Maastricht was, en is Bertha van Knippenberg-van den Berg. Bertha, rustige stille harde werker, met al je kleine gele papiertjes waarmee je altijd bergen verzet: dank je!

Tenslotte, voor je voortdurende ondersteuning, voor je gezonde verstand, voor dat je de beste 'multi-tasker' bent die ik ken, organisatie-wonder, hulp en sparring partner, en boven alles voor dat je een vriendin bent, dank je mevrouw Kerkhofs, dank je Ellen.

Nu u zover gekomen bent vraagt u zich misschien af wat ik eigenlijk zélf gedaan heb. Ik denk dat ik het tempo in dit project heb gehouden. Dat is mogelijk geweest door een aantal zaken. Ik wil daar én uitlichten. Ik denk dat het helpt als je een onderwerp goed kent woordat je het bestudeert. I weet wat er speelt op het gebied van communicatie vaardigheidstraining. Ik ben me ervan bewust dat dit geholpen heeft deze onderneming met plezier te volbrengen. Ik kan het aanbevelen.

Maastricht, Mart 2001 


\section{Preface}

T was at the eighth annual Dutch conference on health prolessions education, in November 1998 that Bertha van Knippenberg-van den Berg and 1 had our first talk about a possible collaboration that was to lead to the findings reported in this dissertation. That was exactly 20 years after I had started to work at the Skillslab.

It is hardly an original thought, but a dissertation is the result of a collaboration for which one gets the credits. Many people deserve my gratitude.

My parents are the first to receive my thanks, in the first place because they all. lowed me to study. They have always respected my choices. Moreover, they helped me to develop a talent that I cherish: being able to enjoy things. I have also learned much from being with my sons, Arjen and Thijs. They kept me with my feet on the ground whenever I was "contributing to science".

One of the main things that this work has taught me is that so many people empathise and are willing to assist. To give an example: the 50 or so observers that I approached to join the train to Leiden a couple of times, responded to my e mail within the week, most of them positively and all of them constructively. I want them all to know that I am very thankful.

Even within this benevolent culture, some are more equal than others, and I like to mention them here.

To begin with, my supervisors: Cees van der Vleuten and Albert Scherpbier. You guys are true Professors, in many fields. Specifically because of your knowledge of the field of medical education, wisdom, scientific rigour, continuous support and consitant speed you deserve to be called the best supervisors one could wish. On most drafts, I received specific feedback within two days, inclusiwe of suggestions for alternative formulation of unclear expressions. This alone already makes you, together with Ellen, the ACE of supervision. The constant encouragement and fun did the rest. II $\mathrm{O} U$.

For the construction of the knowledge about communication skills test, I was inspired by Lambert Schuwirth and helped by Maarten Verwijnens encouraging 
punctuality. By himself, Jan-Joost Rethans motivated almost the entire fourth year medical students group in Maastricht to participate in this test.

For comments on the items for the respectful conduct scale, I thank Susan Böge]s, Hanneke Hamers, Paul Ram, Albert Scherpbier, Jacques van Thiel and Cees van der Vleuten. Margriet Brorens and Desirée Bronckers helped in realising the logistics of the respectful conduct scale, and Guus Smeets and Ron Hoogenboom assisted in the statistical processing of this instrument.

Developing the cases for the multiple station examination was greatly helped by these doctors: Marjo Boumans, Jolanda Land, Jeroen Koomans and Jan-Joost Rethans. Giel Peeters, Rob Schonck and Jos op 't Root supported my breaking in in the clerkship general practice. Kiki Nittel and Meline den Heyer from the Department of Gynaecology and Obstetrics, Leiden University Medical Centre, allowed us time from their training programme.

Paul Ram, Jacques van Thiel and Cees van der Vleuten let me use the video equipment, which Michiel Jans assisted in installing.

This whole endeavour would not have been possible without the 1414 participating students.

I am also grateful to the raters from Maastricht and Leiden: Loes van Bokhoven, Marjo Boumans, Chantal Caes, Ingrid Candel, Diana Dolmans, Saskia van Es, Marie-Jeanne Haack, Marie-Anne Haenen, Beppie Hellemons, Marlies Huitema, Lidewij Jansvedel, Helen Koch, Marie Jeanne Kooiman, Susanne Niemantsverdriet, Marijke Perquin, Myriam de Ruyter, Marjolein de Vries, Ineke Wolfhagen, Pie Bartholomeus, Niels Chavannes, Rob van Diest, Paul Falger, Michiel Jans, Bart Leunissen, Patrick wan Limpt, Rutger Lulofs, Albert Scherpbier and Maarten Verwijnen.

Simulated patients from Maastricht and Leiden enthusiastically travelled to the other end of the country: ms M. Aelterman, ms J. Ammeraal, ms A.J. Beekman, ms A. Buckinx, ms K. van Hamsvoort, ms A. Hintzen, ms J. Kerbusch, ms M. Lucassen, ms H.A.M. Rijkelijkhuizen, mr N. Heuts, mr W. Huveneers, mr F. Martens, mr Th. Rommens, mr V. Schoonderwalt, mr J.J. Schrumpf, mr J. Tillie and $\mathrm{mr}$ W. Winten.

There have been numerous co-authors and those who otherwise were in the firing line of my requests for feedback on draft articles, I am grateful to you all. Pie Bartholomeus supported me throughout all the years that we share at the Skills-
lab, thank you Pie!

Ladies of the Skillslab secretariat at that time, thank you for your organisational work (letters, registrations, trouble-shooting, feedback to students): Juliana Been, Esther Colberts, Marleen van Zandvoort and especially my heart-friend, the irreplaceable Rina Herpers-Gibbels. Rina, thank you also for helping me to maintain a
minimum of stability. 
Geke Blok, Geke, didn't we almost have it all?' We have our complicated history. I thank you for many things, including sharing our attempts to study education. once clarified by a mutual colleague as: "measuring what cannot be measured". "

Katinka Prince, I greatly appreciate your contimuous interest. support, fun and being a great friend.

This preface is probably the only chapter that reflects my own command of English. That is because it is the only piece that has not been anglicised by Mereke Gorsira. For turning my texts into English worth wearing spectacles for, for your incredible treatment of both the English and Dutch language, as well as for your friendship, thanx Mereke.

My colleagues of the Skillslab staff create an exceptional atmosphere of mutual support. Thank you all. I am proud to be working here.

Ieta van den Hout, thank you for your enthusiasm, for your many ideas, and for the support that you have always given.

Indispensable for the success of the cooperation between Leiden and Maastricht has been, and is: Bertha van Knippenberg-van den Berg. Bertha, you quiet silent worker, with your many pieces of yellow paper that always resulted in moving mountains: thank you.

Finally, for your continuous support, your healthy common sense, for being the master of multi-tasking, an organisational wizard, help and sparring partner, and most of all for being my friend: thank you ms Kerkhofs, thanks Ellen.

After reading all this, you may wonder what I have done myself: I think that I have kept up the speed in this project. This has been possible by a number of things. I would like to point out one. I think that it helps to know a field before studying it. I know the field of communication skills training, and I am aware that this has helped me to fulfil this endeavour and enjoy it. If can recommend it.

Maastricht,

March 2001

1 Sinatra F. Didn't we almost have it all. Capitol records; 1958

2 Sells R. EDHEP UK Working group meeting. Liverpool; April 22, 1994. 
$s$ 


\section{Introduction}

Since Barbara Korsch et al.'s influential publication about the communication $S$ between mothers of ill children and their paediatricians, in 1968, the importance of doctor-patient communication has steadily gained recognition.' In the past decade communication skills were acknowledged as a core competence for health care practitioners. $^{2-4}$

Helfer's study showed that without formal training communication skills of medicall students deteriorate during medical school. ${ }^{5}$ These findings have been replicated in several studies since then. ${ }^{6-8}$ Students enter medical school as relatively unbiased listeners, very capable of empathising. As they proceed through the medical curriculum, they gradually acquire the knowledge and insights needed to address patient problems: making the correct diagnosis and conveying understanding and empathy to the patient. It is difficult for students to integrate their natural compassion with the task of discovering relevant facts in the patient's history. There is a real risk that they will lose their empathic abilities as they concentrate more and more on medical knowledge and skills. This has prompted the development of communication skills training programmes in medical curricula."

The wide diversity of teaching goals in these programmes was mainly due to a lack of well-defined, uniform criteria. How were the skills operationalised? The main distinction was between those who concentrated on 'attitude', with the emphasis on personal awareness, and those who used observable behaviour as the focus of training. ${ }^{10}$

Based on an increasing body of research, performance criteria for communication skills have been developed, aimed at achieving the highest patient compliance and patient satisfaction. ${ }^{9}$ Guidelines for different training formats have also been published, ${ }^{9,2-15}$ as well as recommendations about the optimal period in a curriculum for training to have effect. ${ }^{9.15}$ These guidelines, unfortunately, are by no means conclusive, sometimes even downright contradictory. For example: some findings suggest that training should be helical; i.e. training should continue throughout the curriculum, with opportunities for students to refresh, expand and elaborate on skills learned earlier in the course, $9.16-19$ whereas other studies have provided evidence that the largest effect of communication skills training can be achieved by courses in the clinical period of the medical curriculum. ${ }^{15}$ 
These contradictory findings from the literature have inspired the main research question addressed in this dissertation: which factors in the medical curriculum influence the effectiveness of communication skills training?

Regatding curriculum evaluation, Donabedian distinguished between curricular structure, process and outcome. ${ }^{20}$ A curriculum can be evaluated by looking at its structure: what is known of the curriculum 'on paper'. 21 Instruments that can be used for evaluating the curriculum stucture are document analyses and interviews with those responsible for the programme. 22

What actually goes on inside the learning environment, the process of the curriculum, is best judged by its consumers, the students. ${ }^{23}$ Questionnaires have proven to be valid tools for the assessment of students' opinions about aspects of the curriculum. 2.46

Finally, a curriculum can be evaluated by addressing its achievements, curriculum outcome. The preferred test format for the assessment of communication skills appears to be an Objective Structured Clinical Examination (OSCE). ${ }^{27-32}$ Different instruments are used for the assessment of communication performance in an OSCE. Various checklists for the assessment of students' performance have been described, ${ }^{33-37}$ each with their own psychometric characteristics. The main drawback of all instruments is that they suffer from case specificity. Large numbers of measurements are necessary to reach a sufficiently generalisable judgement of communication skills. Moreover, most of these instruments require substantial resources as they can only be used by highly trained examiners. Studies looking for possibilities to reduce testing time in OSCEs focus, among other things, on the partial replacement of performance tests by knowledge tests. ${ }^{3} .39$

\section{RESEARCH QUESTIONS}

The core question addressed in this thesis is: which factors in the medical curriculum influence the effectiveness of communication skills training. In order to answer this main question we tried to identify how medical students' communication skills develop throughout the curriculum. This led to the following specific research questions:

1. How is the communication skills training programme organised? What has been described, and how is it intended? How does this curriculum "on paper" relate to the relevant literature? (Structure)

2. What do students perceive to be the most influential contributions of the curriculum to their communication skills? (Process)

3. What are the psychometric characteristics of three types of instruments for the assessment of communication skills (i.e. a checklist of performance, a concise global rating scale for performance and a test of knowledge about skills)? This 
methodological question had to be answered before the next research question could be addressed:

4. How do students" communication skills develop in a longitudinal versus a concentrated training programme? (Outcome)

\section{STUDIES}

The studies originated at the Skillslab of the medical school of the University of Maastricht, the Netherlands. The structure of the Skillslab's communication skills training programme has been analysed. Interviews with participants in its development and relevant documents were used for this analysis.

The process of the communication skills training programme was studied by surveying students' opinions about the programme. What do they find particularly interesting and what, in their judgement, contributes most to their learning?

The outcome of the communication skills programme is the major topic of this dissertation. First we studied the psychometric properties of three instruments to assess communication skills: a detailed checklist of performance, a concise global rating scale of performance and a test of knowledge about communication skills. These instruments were then used to compare the communication skills of students from two Dutch medical schools: Maastricht and Leiden. These schools were chosen because they showed the widest diversity in programming in a formal comparison of Dutch medical schools' attention to communication skills. ${ }^{40}$

\section{OUTLINE OF THE THESIS}

\section{Chapter 1: Teaching and assessing communication skills in Maastricht}

This chapter gives an overview of the communication skills curriculum of the medical school of the University of Maastricht, as it is described 'on paper'. Its development and the problems encountered are described and related to literature. This chapter provides a context for the study to the readers who are not familiar with this curriculum.

\section{Chapter 2: Factors influencing the effectiveness of communication skills training}

This chapter reports students' opinions about the elements of the Maastricht programme that make an effective contribution to the development of their communication skills. 
Contributions of various aspects of the progtamme to this leaming effect are analysed, with the learning effect reported by the students as dependent variable.

\section{Chapter 3: Construct validity of the MAAS-Global}

The construct validity of an instrument for the measurement of the quality of communication skils is studied. The first and last simulated patient encounters in one year of the four year communication skills training programme in Maastrich were assessed by examiners who were blinded to which of the encounters they rated. The performance gailn was determined.

\section{Chapter 4: Integrated assessment of communication skills}

This chapter presents the results of an investigation of the possibility for increasing the generalisability of the measurement of communication skills in the anmual OSCE of Maastricht medical school. A simple, three-item scale was added to the checklists of the stations in which clinical procedural skills are assessed with the help of a standardised patient. The construct validity of the three-item Respectful Condtict Scale was evaluated by comparing the scores on this scale with the scores on a detailed checklist designed to assess communication skills and the scores on the rest of the OSCE. The generalisability coefficients of the RCS, of a detailed checklist for the assessment of communication skills, of their combination and of the other stations of the OSCE were compared.

\section{Chapter 5: Predicting communication skills with a paper-and-pencil test}

The value of a written knowledge test of communication skills for predicting scores on a perfomance test of communication skills was investigated. In an experimental setting students from the medical schools of Maastricht and Leiden, the Netherlands, participated in the two tests. The correlation between the results was calculated.

\section{Chapter 6: Longitudinal and concentrated communication skills programmes compared}

The effectiveness of the communication skills curricula of the medical schools of Maastricht and Leiden, the Netherlands, was compared, using a performance test. Both schools have a six-year undergraduate medical curriculum, divided into four preclinical years and two years of clinical clerkships. The performance test was 
taken by students at the end of the preclinical period and towards the end of the final year. The Maastricht problem-based curriculum offers an integrated clinical skills training programme, including communication skills, which runs throughout the first four years. Communication skills training in Leiden is concentrated in short courses in the preclinical phase, at the beginning of the clinical phase and preceding two clerkships.

\section{Chapter 7: Development of communication skills in the medical curriculum}

To compare the development of students' communication skills in a longitudinal versus a concentrated programme, a knowledge test of communication skills was administered to students of all six years of the medical schools of Maastricht and Leiden, the Netherlands, in a cross-sectional design. The score patterns per school were interpreted in the light of the communication skills training programmes.

\section{Conclusions and discussion}

The findings of the studies reported in this dissertation are synthesised and the answers to the research questions are discussed. Recommendations are made regarding the place of communication skills training in the medical curriculum and areas for further research.

Since this dissertation consists of articles that have been published in, or submitted to different journals, some duplicate information could not be avoided.

\section{LITERATURE}

1. Korsch BM, Gozzi EK, Francis V. Gaps in doctor-patient communication. Pediatrics 1968:42:855-71.

2. GMC, Educational Committee. Tomorrow's doctors. London: General Medical Council; 1993.

3. World Health Organisation. Doctor-patient interaction and communication. Geneva: World Health Organisation; 1993.

4. AAMC. Report III. Contemporary issues in medicine: communication in medicine. Medical schools objectives project. Washington: Association of American Medical Colleges; 1999. 
5. Helfer RE. An objective comparison of the paediatric interviewing skills of freshmen and sewior students. Pediaurics 1970;45:623-7.

6. Poole AD, Sanson-Fisher RW. Understanding the patient: a neglected aspect of medical education. Social Science and Medicine 1979;13 A:37-43.

7. Bishop JM, Fleetwood-Walker P. Wishart E, Swire H, Wright AD, Green ID. Competence of medical students in history taking duning the clinical course. Medical Education $1981 ; 15: 368-72$

8. Pfeiffer C, Madray H, Andolino A. Willms J. The rise and fall of students" skill in obtaining a medical history. Medical Education 1998;32:283-8.

9. Kurtz S, Silverman J, Draper J. Teaching and leaming communication skills in medicine. Oxon: Radcliffe Medical Press; 1998.

10. van Dalen I. Attitude ontwikkeling en sociale vardigheden: complementair? [Attitude development and communication skills: complementary?] In: Dochy FJ, van Luijk SJ, editors. Handboek Vaardigheidsonderwijs Lisse: Swets \& Zeitlinger; 1987.

11. Silverman J, Kurtz S, Draper J. Skills for communicating with patients. Oxon: Radcliffe Medical Press; 1998.

12. Caroll JG, Monroe J. Teaching clinical interwewing in the health professions. A review of empirical rescarch. Evaluation in the Health Professions 1984;3:21-45.

13. Pendleton D. Schofield T. Tate P, Havelock R. The consultation: an approach to learning and teaching. Oxford: Oxford University Press; 1984.

14. Ong LML, de Haes JCJM, Hoos AM, Lammes FB. Doctor patient communicam tion: a review of the literature. Social Science and Medicine 1995;40:903 18 .

15. Aspregren K. BEME guide no. 2: Teaching and leaming communication skills in medicine all review with quality grading of articles. Medical Teacher $1999 ; 21: 563-70$.

16. Rutter DR, Maguire P. History taking for medical students II: evaluation of a training programme. Lancet 1976;226:558 60 . 
17. Riccardi VM, Kurtz SM. Communication and counselling in health care. Springfield, 11.: Charles C. Thomas; 1983.

18. Flaherty JA. Education and evaluation of interpersonal skills. In: Rezler AG, Flaherty A, editors. The interpersonal dimension in medical education. New York: Springer Verlag; 1985.

19. Maguire P, Fairbairn S, Fletcher C. Benefits of feedback training in interviewing as students persist. British Medical Journal 1986;292:1573-8.

20. Donabedian A. The quality of care. How can it be assessed? Journal of the American Medical Association 1988;260:1743-8.

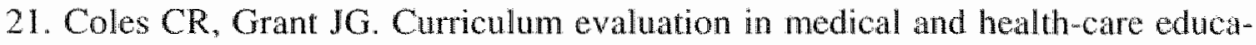
tion. Medical Education 1985;23:228-41.

22. Remmen R. An evaluation of clinical skills training at the medical school of the University of Antwerp. [dissertation] Antwerp: University Press; 1999.

23. Visser K, Prince CJAH, Scherpbier AJJA, van der Vleuten CPM, Verwijnen GM. Students can be full partners in designing their education. Academic Medicine 1997,72:1034-5.

24. Gijselaers WH. Kwaliteit van het onderwijs gemeten: Studies naar de betrouwbaarheid, validiteit en bruikbaarheid van studentoordelen. /Measuring quality of education: studies of reliability, validity and feasibility of student judgements) [Dissertation] Maastricht: University Press; 1988.

25. Dolmans DHMJ, Wolfhagen HAP, Schmidt HG, van der Vleuten CPM. A rating scalle for tutor evaluation in a problem-based curriculum: validity and reliability. Medical Education 1994;28:550-8.

26. Cook DA, Brown LM, Skakun EM. Factors which influence the outcome of student evaluation of teaching. In: Scherpbier AJJA, van der Vleuten CPM. Rethans J-J, van der Steeg AFW, editors. Advances in medical education. Dordrecht: Kluwer Academic Publishers; 1997.

27. Harden RM, Gleeson F. Assessment of clinical competence using an objective structured clinical examination. Medical Education 1979;13:41-54. 
28. Stillmar PL, Swanson DB. Ensuring the clinical competence of medical school graduates through standardised patients. Archives of Internal Medicine $1987 ; 147: 1049-52$.

29. Langsley DG. Medical competence and performance assessment: a new era. Joumal of the American Medical Association 1991;266:977-80.

30. Vu NV, Barrows H, Marcy M, Verhulst SJ, Colliver JA, Travis T. Six years of comprehensive clinical performance based assessment using standardised patients at the Southern Illinois University School of Medicine. Academic Medicine 1992;62:42-50.

31. $\mathrm{Yu} \mathrm{NV}$, Barrows $\mathrm{H}$. Use of standardised patients in clinical assessments: recent developments and measurement findings. Educational Researcher 1994;23:23-30.

32. Pololi LH. Standardised patients: as we evaluate so shall we reap. Lancet 1995;345:966-8.

33. Stillman PL, Brown DR, Redfield DL, Sabers DL. Construct validation of the Arizoná Clinical Interview Rating Scale. Educational and Psychological Measurement 1977;37:1031-8.

34. Kraan HF, Crijnen A. The Maastricht history taking and advice checklist: studies of instrumental utility. [Dissertation] Maastricht: University Press; 1987.

35. Bensing $\mathbb{J}$. Doctor-patient communication and the quality of care. An observation study into affective and instrumental behavior in general practice. [Dissertation]. Utrecht: Nivel; 1991.

36. van Thiel J, Kraan HF, van der Vleuten CPM. Reliability and feasibility of measuring medical interviewing skills: the revised Maastricht history taking and advice checklist. Medical Education 1991;25:224-9.

37. Roter DL, Hall JA. Doctors talking with patients, patients talking with doctors. Westport, CT: Auburn House; 1992.

38. van der Vleuten CPM, van Luijk SJ, Beckers HJM. A written test as an alternative to performance testing. Medical Education 1989;23:97-107.

39. Verhoeven BH, Hamers JGHC, Scherpbier AJJA, Hoogenboom RJI, van der Vleuten CPM. The effect on reliability of adding a separate written assessment 
component to an objective structured clinical examination. Medical Education $2000 ; 34: 525-9$.

40. Wouda J, van de Wiel HBM. Communicatieve vardigheden: een diagnose en een advies. [Communication skills: a diagnosis and an advice] Bulletin Medisch Onderwijs 1992:11:116-8. 


\section{CHAPTER 1}

\section{Teaching and assessing communication skills in Maastricht ${ }^{1}$}

Tn order to share the issues involved in setting up a communication skills training I programme in a medical school, the development of such a programme at the Skillslab of Maastricht medical school "The Netherlands, is described and the problems encountered are addressed.

A multidisciplinary working group developed teaching goals for communication skills, focused on observable behaviour to be displayed by students. These teaching goals were incorporated in a generic model for doctor-patient communication. A longitudinal training programme was created, throughout the four years of the preclinical curriculum. Students meet in small groups of ten, once every two weeks. In between group sessions they practise consultation skills in simulated patient contacts. Communication skills are assessed in the annual multiple station examination.

In the development of this programme the following consecutive actions were taken: teaching material was produced, an assessment tool was developed, as were instruments for programme evaluation. The programme evaluation allowed student feedback to teachers, the teachers' departments, and the administration of the medical school. Finally, teacher training was professionalised.

\footnotetext{
'Published as: van Dalen J, Bartholomeus P, Lulofs R, van Thiel I, Rethans J-I, Scherpbier AJJA, van der Vleuten CPM. Teaching and assessing communication skills in Maastricht: the first Iwenty years. Medical Teacher 2001:23:245-51.
} 


\section{INTRODUCTION}

Communication is essential to almost all aspects of health care, from history taking to providing information to the patient. "History taking contributes $60-80 \%$ of the data for diagnosis. ${ }^{2-5}$ Since Ley's study on information giving it has been assumed that patients" capacity to remember items explained to them is captured by the equation: [number of items remembered $=1 / 2 x$ number of items told -1$]{ }^{6}{ }^{6}$ However, further studies by Tuckett \& Williams, emphasised that it is not so much the number of items that is important, but rather their significance to the patient. Evidence about the significant influence of communication skills on the adherence to the doctor's advice is reported. Non-compliance in medicine is well described: more than hall of the patients deviate from their doctors" advice or do not follow it at all. 8 .

Dissatisfaction is expressed in studies about the quality of communication in every phase of the medical encounter. Studies by Beckman and Frankel indicated that doctors intermpt their patients" opening statements after a mean interval of $18 \mathrm{sec}$ onds." Furthermore, patients do not always understand what the doctor explains, advice is not always an answer to the patient's questions or the advice may be too difficult to act upon.

Communication is an interactive process. A person"s experience and education strongly influence how information is interpreted. This idiosyncratic way in which an individual interprets information is often referred to as a person's frame of reference. A doctor and a patient will view a health complaint from different frames of reference. ${ }^{12}$ For the patient, a complaint is a matter of alam. There have always been events prior to the decision to visit the doctor. The patient will often have limited information about the medical background and has his/her own interpretations of what the complaint might signify. For the doctor, a patient's complaint represents a matter of logic. The doctor is a medical expent, to a certain extent responsible for making the diagnosis and giving advice.

Communication is likely to be effective when both parties (patient and doctor) atwibute the same meaning or significance to the words and the non-verbal information that is exchanged. Effectiveness of communication improves when the doctor actively unes to understand the patient's perspective, including the patient's situation, beliefs, point of view, fears, worries and attributions, and when the doctor is able to share this understanding with the patient."

Improved doctor patient communication has been shown lo nesult in: increased satisfaction of patients, 4.14 increased cooperation of patients, 15 no increase in time spent with patients, ${ }^{10}$ decreased duration of treatment, $15,17-19$, decreased duration of hospitnl stay, ${ }^{20}$ fewer roquests for painkillers, ${ }^{21}$ and fewer malpractice suits. ${ }^{22}$ The quality of doctor patient communication can be improved by training. ${ }^{23}$ Some
elententary findings are; 
- any training is better than no training 24,25

- training with practising is better than traditional instruction methods based on the acquisition of knowledge alone ${ }^{26}$

- longitudinal training is better than concentrated training ${ }^{27}$

- there is no systematic difference in teaching by teachers of different disciplines. $28-31$

It is for these reasons that health care organisations have recommended that conmunication skills training should be an integral part of any medical curriculum. 32.33 Developments like these motivated the Maastricht medical school to organise an aborate communication skills training programme within the medical undergraduate curriculum.

In this article the development of this programme during its first twenty years will be described. First the generic model for doctor-patient communication is described, then the organisation of communication skills teaching in the Skillslab is addressed. Stages in the development are dealt with, and some problems described. In the final, section plans for the coming years are outlined.

\section{GENIERIC MODEL FOR DOCTOR-PATIENT COMMUNICATION}

Where possible a programme's teaching objectives should be clear to students at the very start of the programme. ${ }^{3: 4}$ These objectives should preferably be operationalised as observable behaviour. At Maastricht medical school an interdisciplinary working group (general practice, surgery, internal medicine, psychiatry, nursing, social work and psychology) developed a generic model for doctor patient communication, based on literature findings. $13,25,38$ The model distinguishes three phases of the medical encounter. In the first phase the patient is the expert. The patient knows why he has come to see the doctor, his worries, anxieties and atubutions and his individual request of the doctor. In this phase, the doctor should isten, explore and be receptive to the patient's concerns.

In the next phase the doctor is the expert. By means of directive questioning the doctor translates the patient's complaint into a medical frame of reference. Systems review is a part of this phase, as well as physical examination, in which clarity of instruction and sensitive courteous behaviour are especially important, because the patient is often in a vulnerable position.

In the third and final phase both doctor and patient are experts, each in their own field. The doctor knows what can be done, including potential alternatives. It is the doctor's responsibility to clarify these alternatives and their likely consequences. However, the patient judges the alternatives in the light of his own circumstances. possibilities and preferences.

In recent years this model has been further supported and refined by a growing body of experiences and evidence. 
Appropriate elementary communication skills for each of these phases have been formulated and operationalised. This allowed for specific teacher guidelines ${ }^{48}$ and an assessment tool, the MAAS-GIobal, ${ }^{4149-51}$ which will be addressed in following sections.

\section{ORGANISATION AND STRUCTURE}

The preclinical curriculum of Maastricht Medical School is organised in blocks of six weeks. In each block a type of patient problem is the focus of interest in problem based learning groups. ${ }^{52}$ Skills are taught in a separate department: the Skillslab. ${ }^{53.54}$ Communication skills training should be integrated with the teaching of theory, the training of other skills (i. e physical examination skills) and the assessment system. It has been demonstrated that longitudinal training is better than concentrated training. ${ }^{27}$ There are indications that communication skills do not spontaneously improve without training and may even deteriorate during a medical curriculum. 55.58 That is why training should ideally be organised longitudinally, parallel to the other curricular activities.

For communication skills training groups of ten students meet once every two weeks with one or two facilitators (see figure 1). The composition of the groups, both stadents and teacher(s), remains the same throughout the academic year.

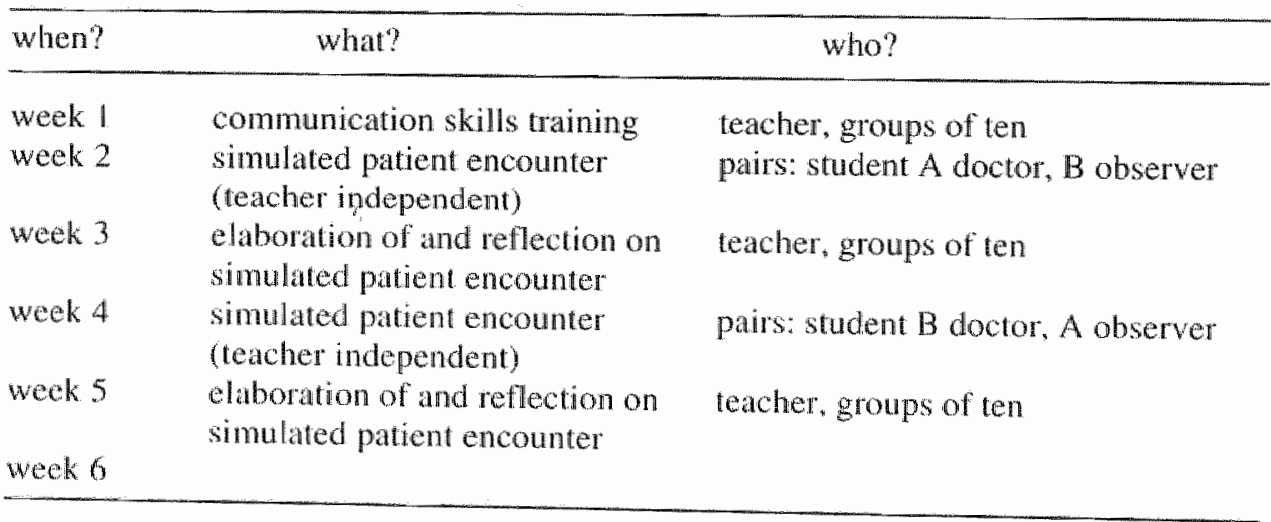

Figure 1. Organisation of communication skills training per block of six weeks

In the first and second years the first group meeting in each block is devoted to communication skills training. in which a variety of teaching formats is used: exercises, role play and video vignettes. In the second week of all blocks in every year, pairs of students take part in teacher-independent simulated patient encounters, with all simulated patients portraying a similar role which is relevant for the theme of the block. For example, in the block on Abdominal Complaints the role of the 
simulated patient in week 2 is: abdominal pain, caused by Crohn's disease. Pairs of students record the encounter on their own videotape. The student who plays the "doctor" role performs an entire consultation, including physical examination and management, while displaying his or her communication skills throughout. The encounter is followed by a brief time-out, after which the student asks feedback from the simulated patient about his or her experiences as a patient during the encounter.

In the following days, all students plus their teacher(s), individually watch the videotapes of the five pairs of their group. The students who have played the doctor"s role have to fill out a form to share their learning goals and formulate specific questions to the other students and teacher(s) who watch the tape.

In the third week, when all group members have watched the tapes, the group reconvenes, with the teacher, to elaborate and reflect on these encounters. Feedback is asked and given and alternative approaches to the communication with this patient and his or her problem are tried out. Medical aspects are exchanged, the students' 'trains of thought' are made explicit and, if necessary, corrected. Ethical issues are also discussed. Subsequently, the student 'doctors' formulate new learning goals, to be addressed during communication skills training sessions and simulated patient encounters in the following blocks.

This procedure is repeated in weeks 4 and 5 , with a similar type of complaint (e.g. in the block on Abdominal Complaints these complaints are now indicative of an appendicitis or an ectopic pregnancy), but now the other student of the pair is the 'doctor'. At the end of the block all students have formulated new, or refined learning goals. This whole cycle is repeated in the next blocks. During the four years of the programme, the students practise being a doctor about 20 times, and directly observe another 20 consultations. On videotape they observe about four more students per consultation. It is impossible to identify exactly how much of this time each student spends exclusively on communication skills. To give a rough average: in four years each student participates in 102 hours teacher-guided small group sessions and individually watches an additional 68 hours video recordings of their own, and fellow-students" simulated patient encounters. Assuming that during this time attention to the medical content and communication skills is divided equally, students spend 85 hours in total addressing communication skills. Of these 85 hours, 51 hours are spent with a teacher and 34 hours in teacher-independent training activities.

Because of their training, behavioural scientists are expected to have the necessary expertise to teach communication skills. However, students also value the opportunity to identify with their teachers and may prefer doctors. In the course of the curriculum medical knowledge and problem solving are increasingly integrated into the programme. For these reasons behavioural scientists facilitate the groups in the 
first year, but medical doctors do so in the second year. In the third and fourth years each group is facilitated by wo teachers, a doctor and a behavioural scientist. An overview of the programme is given in figure 2 .

\begin{tabular}{|c|c|}
\hline Year & Core elements \\
\hline 1 & $\begin{array}{l}\text { emphasis on elementary communication skils related to information seeking } \\
\text { (asking different types of questions; summarising, reflecting feelings, clarifying } \\
\text { the patients teason to visit the doctor). Students practise in entire doctor-patient } \\
\text { encounters with simulated patients who play relatively easy cases. }\end{array}$ \\
\hline 2 & $\begin{array}{l}\text { emphasis on information giving and shared decision making, culminating in } \\
\text { breaking bad news. These skills are practised in entire doctor-patient encounters } \\
\text { with simulated patients. }\end{array}$ \\
\hline 3 & $\begin{array}{l}\text { emphasis is on history taking. Students also practise special interview situations: } \\
\text { history taking and management of patients with psychiatric problems and pa- } \\
\text { tients with chronic pain. The third year ends with a simulated surgery during } \\
\text { which the students see three simulated patients in one hour. }\end{array}$ \\
\hline 4 & $\begin{array}{l}\text { communication skills training is fully integrated in the simulated patients pro- } \\
\text { gramme. The simulated patients" roles are less strict representations of the block } \\
\text { themes. In the fourth year a simulated office hour of four patients takes place. } \\
\text { The fourth year ends with an disaster simulation" in which students have to deal } \\
\text { with various emergency situations. } 5 \text { " }\end{array}$ \\
\hline
\end{tabular}

Figure 2. Overview of the communication skills training programme in the Skillslab

\section{STAGES IN DEVELOPMENT}

The programme has not been brought about overnight, the development took place in stages. First the main activitics were directed at the production of teaching materials. Then an adequate assessment tool was designed. The next step was to systematically ask the students" opinion about this programme, in order to adapt and improve it and to receive information about the teachers" skills. Based on the students" evaluations, a teacher training programme was developed. 


\section{Teaching materials}

For the teaching of about 800 students, in four year groups of about 200 , some 120 teachers are involved, each investing about 0.05 Full Time Equivalent. Thus, overall 6 FTE's are involved in communication skills teaching, closely integrated with medical problem solving. To ensure uniform teaching, a detailed training protocol has been written for each session, containing:

- the teaching goals;

- preparatory material (literature, hand-outs);

- a time schedule;

- a chronological description of steps to be taken: presentation, introduction of the role play, role of the patient, role of the doctor, assignments for the students who observe the role play, topics for which the role was written, feedback rules, guidelines on how to stimulate involvement of the observing students, topics to be addressed during feedback, evaluation of the training and preparatory advice for the next training.

A schematic example of a protocol can be found in van Dalen et al. ${ }^{48}$ For the sessions following the simulated patient encounter the protocols include:

- a description of the complaint portrayed by the simulated patients, and the variations per individual simulated patient;

- diagnosis and medical background.

\section{Assessment procedures}

The assessment system should reflect the educational system. Furthermore it is often claimed that assessment is a strong driving force to guide students" study behaviour. ${ }^{60.61}$ Once a year the students participate in a multiple station examination of skills, which always includes communication skills. In 1981, the development of a reliable assessment instrument was undertaken, which has resulted in the MAASGillobal. ${ }^{41.49-51}$

Case-specificity limits generalisabilty of assessment of communication skills in one twenty minute station. This means that we cannot give the students a separate pass mark for their communication skills; instead the performance on communication skills adds information to the mark they receive for the entire clinical skills domain. Furthermore, knowledge about communication skills is assessed in the block tests and progress tests.

\section{Programme evaluation}

Programme evaluation questionnaires have been shown to be reliable techniques to measure students' satisfaction with a course. ${ }^{62-64}$ The communication skills programme is annually evaluated by students and teachers. Students give a judgement about the teachers, which is reported to the teacher, the heads of the teachers' de- 
partments, and the Educational Board of the medical school, as a part of the teachers' portfolios.

The students also judge the instructiveness of the programme as a whole and its components. Analysis of the contribution of the teachers' didactic skills and the components of the programme to its instructiveness revealed that, according to the students' perceptions, more than half of the learning effect was explained by the content of the programme (communication skills training accounting for $37 \%$ of the variance) while only $5 \%$ of the remaining variance was explained by the didactic skills of the teacher.

There is no systematic difference between the judgements about teachers from different disciplines. Students express pronounced preferences for individuals, but these are not reflected in the reported learning effects. Students find the programme very instructive during the four years they participate in it, ${ }^{6.5}$ as well as during the clerkships, looking back on the programme. ${ }^{66}$ The quality of the simulated patients, feedback is a continuous matter of concern. We need to train our simulated patients repeatedly in giving the information that only they are experts in: their experiences during the encounter.

\section{Teacher training}

Detailed information from the annual programme evaluation provided the course organisers with teaching goals for teacher training. Teacher training programmes address the analysis of videotapes of student-simulated patient encounters, the application of feedback rules, collaboration and division of tasks between a pair of teachers, and the stimulation of student involvement. Attendance at these training sessions is very modest, partly because many trainers have considerable experience. The teacher training programmes have been developed during a pilot phase and soon attendance will be formally recognised as a requirement for new trainers.

\section{Problems}

The programme described above is extensive and organisationally firmly embedded in the infrastructure of the Skillslab. However, this being not the ideal world, many problems remain unsolved. We will review some of them.

\section{Instruction videotapes}

Initially, considerable time, money and energy was invested in video instruction tapes. These tapes were intended as preparation material for training: students could see and hear what behaviour was expected. 
The tapes have never really worked. Quickly outdated clothing and poor acting soon overshadowed the messages of the tapes. The older the tapes became, the more urgent the problem became, so that we finally stopped using video instruction tapes altogether. A video teaching aid that works best in our experience is the video vignettes.

An example would be a half total shot of a patient, looking squarely into the camera and speaking an intriguing line, like: 'doctor, I have come to say goodbye, and thank you for everything you have done for me, but I can't face life anymore. Tomorrow I will be gone." The screen goes blank after that.

These vignettes are used in group sessions. Students are asked to write down what they have seen and heard, how it affects them and what in their view would be an adequate professional reaction. Their answers are exchanged and discussed. With these video vignettes the students' attention is immediately captured and most see the relevance of this exercise right away.

\section{Entire consultations for first year students?}

Originally, different phases of the consultation were trained in different curriculum years. 'Clarifying the patient's reasons to visit the doctor' is an ideal topic to start with in the first year, because the students at that stage do not have much medical knowledge. This means that they can be unbiased listeners, and appreciate and acknowledge the information that patients spontaneously share. When medical knowledge increases, it becomes more difficult for the students to integrate the patients agenda (a complaint; alarm) with their own agenda (problem solving; logic). We have frequently observed that students listened less attentively in later curriculum years than they did in the first year, as has earlier been found. ${ }^{56-58}$ We therefore changed the content of training sessions to entire consultations, even for first year students. In this way students from the onset practise integrating giving attention to the patient with problem solving. However, a drawback of this approach has been that it is quite difficult to create cases with which first year students can confidently practise.

\section{Choice for behaviour as the topic of training}

Probably not all aspects of human interaction can be expressed in observable behaviour. For example: we have not succeeded in developing unambiguous criteria for 'eye contact". It can be argued that we pay too little attention to what might be indicated with the word 'attitude'. Although every simulated patient encounter challenges students to make choices, based on their own norms and values, students and teachers do not always make these choices explicit. In the programme evaluation students regularly indicate that they want more opportunities to address 
"attitudinal issues". Students choose not to address these issues in the group sessions elaborating on simulated patient encounters.

\section{Model truly generic?}

There are some specific occasions in health care communication where the model is not applicable, for example when a patient cannot express himself. These occasions are not addressed in this programme. Furthermore it is often claimed that the way communication skills are defined in the model makes them impracticable and too time-consuming, especially in the hospital setting. However, in light of the current widespread dissatisfaction with doctor-patient communication, this is rather a problem of the organisation of health care than of communication taking too much time. Claims that patient-centred communication takes more time have been proven wrong by research findings. 16

\section{Longitudinal organisation too watered down?}

In this longitudinal programme the driving force should be the individual leaming goals developed by students. However, it remains difficult to maintain the momentum during the weeks between sessions. For five consecutive years a study guide was provided with ample opportunity for students to note their individual learning goals, in order to carry this programme between sessions. Programme evaluations revealed that this was never used (mean: 1.8 on a 5 -point scale, $\mathrm{N}=549$ ). Currently, we hand out leaming goals forms with every simulated patient encounter, and instruct the teachers not to give feedback if no questions or learning goals are provided with the tape.

\section{Limitations of simnlated patients}

Not evcrything can be simulated. ${ }^{68}$ Students know that. This may cause them to avoid physical examination in their simulated patient encounters, especially to wards the end of the programme. We have had some good experiences with mixing the simulated patients with specially invited real patients with stable dysfunctions. and challenging the students to detect which patients are simulated and which are real. Many simulated patients were subsequently declared ill.

\section{THE NEXT YEARS}

A communication skills training programme is never finished. Societal demands are changing, and there are many unknown areas in what actually happens to students while we are teaching. The following developments are under way: 
In order to clarify the effects of this type of training on student learning, and the long term effects on their behaviour, an effect study is currently being conducted, comparing the training programmes of the Maastricht medical school with that of another medical school in the Netherlands.

Furthermore, the radical transition from the preclinical to the clinical part of the curriculum is under revision in Maastricht. This curriculum reform, which aims to make the transition from in-school training to health care more gradual, challenges programme developers to tailor communication skills training to real health care situations.

There are gaps in our programme: multiprofessional collaboration, the demands of a culturally diverse society, greater demand for support and care in changing health care with an ageing population. It will be clear that not every aspect of communication can be offered to every student. We want to educate students to become lifelong learners. There is an increasing need to enhance students' self-assessment abilities. We hope to publish a sequel to this report in some years" time, discussing how we have addressed these issues.

\section{LITERATURE}

1. Silverman J, Kurtz S, Draper J. Skills for communicating with patients. Oxon: Radcliffe Medical Press; 1998.

2. Hampton JR, Harrison MJG, Mitchell JR, Prichard JS, Seymour C. Rejative contributions of history taking, physical examination and laboratory investigation to diagnosis and management of medical out-patients. British Medical Journal 1975;2:486-9.

3. Sandler $\mathrm{G}$. The importance of the history in the medical clinic and the cost of unnecessary tests. American Heart Joumal 1980;100:928-31.

4. Kassirer JP. Teaching clinical medicine by iterative hypothesis testing. New England Journal of Medicine 1983;309:921-3.

5. Peterson MC, Holbrook J, von Hales D, Smith NL, Staker LV. Contributions of the history, physical examination and laboratory investigation in making diagnoses. The Western Journal of Medicine 1992;156:163-5. 
6. Ley $\mathrm{P}$. Communication with patients: improving satisfaction and compliance. London: Croom Helm; 1977.

7. Tuckett D, Williams A. Approaches to the measurement of explanation and information giving in medical consultations: a review of empirical studies. Social Science and Medicine 1984;18:571-80.

8. Sackett DL, Snow DC. The magnitude of compliance and non-compliance. In: Haynes B, Taylor DW, Sackett DL, editors. Compliance in health care. Baltimore, London: The Johns Hopkins University Press"; 1979.

9. DiMatteo MR, DiNicola DD. Achieving patient compliance. The psychology of the medical practitioner's role. New York: Pergamon Press; 1982.

10. Haynes B, Taylor DW, Sackett DL. Compliance in health care. Baltimore, London: The Johns Hopkins University Press; 1979.

11. Beckman HB, Frankel RM. The effect of physician behavior on the collection of data. Annals of Internal Medicine 1984;101:692-6.

12. Schouten JAM. Anamnese en Advies. [History and advice] Houten: Stafleu; 1982.

13. Eisenthal S, Emery R, Lazare A, Udin H. 'Adherence' and the negotiated approach to parenthood. Archives of General Psychiatry 1979;36:393-8.

14. Eisenthal S, Lazare A. Evaluation of the initial interview in a walk-in clinic. Journal of Nervous and Mental Disease 1976;162:169-76.

15. Steward MA. What is a successful doctor-patient interview? A study of interactions and outcomes. Social Science and Medicine 1984;19:167-75.

16. Roter DL, Hall JA, Kern DE, Barker LR, Cloe KA, Roca RP. Improving physicians' interviewing skills and reducing patients" emotional disstress. Archives of Internal Medicine 1995;155:1877-84.

17. Steward MA. Effective physician-patient communication and health outcomes: a review. Canadian Medical Association Journal 1995:152:1423-33. 
18. Spiegel D, Bloom KR, Kraemer HC, Gottheil E. Effects of psychosocial treatment on survival of patients with metastatic breast cancer. Lancet 1989;339:88891.

19. Little P, Williamson $\mathbb{1}$, Warner G, Gould C, Gantley M, Kinmonth AL. Open randomised trial of prescribing strategies in managing sore throat. British Medical Journal 1997;314:722-7.

20. Mumford E, Schlesinger HJ, Glass GV. The effects of psychological intervention on recovery from surgery and heart attacks: an analysis of the literature. American Journal of Psychological Health 1982;72:141-51.

21. Egbert LD, Batitt GE, Welch CE. Reduction of postoperative pain by encouragement and instruction of patients. New England Journal of Medicine 1964:270:825-7.

22. Levinson W, Roter DL, Mullooly JP, Dull VT, Frankel RM. Physician patient communication. The relationship with malpractice claims among primary care physicians and surgeons. Journal of the American Medical Association 1997;277:553-9.

23. Aspregren $\mathrm{K}$. BEME guide no. 2: Teaching and learning communication skills in medicine - a review with quality grading of articles. Medical Teacher $1999 ; 21: 563-70$.

24. Maguire P, Fairbairn S, Fletcher C. Benefits of feedback training in interviewing as students persist. British Medical Journal 1986;292:1573-8.

25. Sanson-Fisher R, Fairbaim S, Maguire P. Teaching skills in communication to medical students -a criticall review of the methodology. Medical Education 1981:15:33-7.

26. Rutter DR, Maguire P. History taking for medical students II: evaluation of a training programme. Lancet 1976;225:558-60.

27. Flaherty JA. Education and evaluation of interpersonall skills. In: Rezler AG, Flaherty A, editors. The interpersonal dimension in medical education. New York: Springer Verlag; 1985.

28. Quirck M, Letendre A. Teaching communication skills to first-year medical students. Journal of Medical Education 1986;61:603-5. 
29. Lynch DJ, Tamburino MB, Nagel R. Teaching interviewing skills: the effect of the instructors academic department. Medical Teacher 1992;14:59-64.

30. Levine JH. Who will teach the skills of history taking and physical examination? Teaching and Learning in Medicine 1995;5:77-8.

31. van Dalen J, van Hout JCHM, Wolfhagen HAP, Scherpbier AJJA, van der Vleuten CPM. Factors influencing the effectiveness of communication skills training: programme contents outweigh teachers'skills. Medical Teacher 1999;21:30810

32. GMC, Educational Committee. Tomorrow's doctors. London: General Medical Council, 1993.

33. AAMC. Repont III. Contemporary issues in medicine: communication in medicine. Medical schools objectives project. Washington: Association of American Medical Colleges; 1999.

34. Lesser AL. Problem based interviewing in general practice: a model. Medical Education 1985;19:299-304.

35. Balint M. The doctor, his patient and the illness. London: Pitman Medical Publishing Co. Ltd; 1957.

36. Byme PS, Long BEL. Doctors talking to patients. London: Her Majesty's Stationary Office; 1976.

37. van Dorp C. Luisteren naar patiënten. [Listening to patients] Lochem: de Tijdstroom: 1977.

38. Riccardi VM. Kurtz SM. Communication and counselling in health care. Springfield, 111.: Charles C. Thomas; 1983.

39. Caroll $\mathrm{JG}$, Monroe $\mathrm{J}$. Teaching clinical interviewing in the health professions. A review of empirical research. Evaluation in the Health Professions 1984:3:21-45.

40. Pendleton D, Schofield T. Tate P, Havelock R. The consultation; an approach to leaming and teaching. Oxford: Oxford University Press; 1984. 
41. Kraan HF, Crijnen A. The Maastricht history-taking and advice checklist; studies of instrumental utility. [dissertation] Maastricht: University Press; 1987.

42. Neighbour, $R$. The inner consultation: how to develop an effective and intuitive consulting style. Lancaster: MTP Press; 1987.

43. Bensing J. Doctor-patient communication and the quality of care. An observation study into affective and instrumental behavior in general practice. [dissertation] Utrecht: NIVEL; 1991.

44. Cohen-Cole SA. The medical interview: the three function approach. St. Louis: Mosby Year Book; 1991.

45. Bird $\mathbf{J}$, Hall A, Maguire P, Heavy A. Workshops for consultants on the teaching of clinical communication skills. Medical Education 1993;27:181-5.

46. Keller VF, Caroll JG. A new model for physician-patient communication. Patient Education and Counseling 1994;23:131-40.

47. Ong LML, de Haes JCJM, Hoos AM, Lammes FB. Doctor patient communication: a review of the literature. Social Science and Medicine 1995;40:903-18.

48. van Dalen J, Zuidweg $\mathbf{J}$, Collet J. The curriculum of communication skills at Maastricht medical school. Medical Education 1989;23:55-61.

49. van Thiel J, Kraan HF, van der Vleuten CPM. Reliability and feasibility of measuring medical interviewing skills: the revised Maastricht history laking and advice checklist. Medical Education 1991;25:224-9.

50. van Thiel J, van der Vleuten CPM, Kraan HF. Assessment of medical interviewing skills: generalisability of scores using successive MAAS-versions. In: Harden R, Hart I, Mulholland $H$, editors. Approaches to the assessment of clinical competence. Proceedings of the fifth Ottawa conference. Centre for medical education, University of Dundee: Scotland; 1992.

51. van Dalen J, Prince CJAH, Scherpbier AJJA, van der Vleuten CPM. Evaluating communication skills. Advances in Health Sciences Education 1998;3:187-95.

52. van der Vleuten CPM, Scherpbier AJJA, Wijnen HFW. Snellen HAM. Flexibility in leaming: a case-report on problem based learning. International Higher Education 1996;2:17-24. 
53. van Dalen J, Bartholomeus P. Training clinical competence in a Skillslaboratory. In: Bender W, Hiemstra RJ, Scherpbier AJJA, Zwierstra RP, editors. Teaching and assessing clinical competence. Groningen; BoekWerk Publications; 1990.

54. van Dalen J, editor. Skillslab, centre for training of skills. Maastricht: University Press; 2000.

55. Helfer RE. An objective comparison of the paediatric interviewing skills of freshmen and senior students. Pediatrics 1970;45:623-7.

56. Poole AD, Sanson-Fisher RW. Understanding the patient: a neglected aspect of medical education. Social Science and Medicine 1979;13A:37-43.

57. Bishop JM, Fleetwood-Walker P, Wishart E, Swire H, Wright AD, Green ID. Competence of medical students in history taking during the clinical course. Medical Education 1981;15:368-72.

58. Pfeiffer C, Madray H, Ardolino A, Willms $J$. The rise and fall of students' skill in obtaining a medical history. Medical Education 1998;32:283-8.

59. Vooijs MEEC, Scherpbier AJJA, van Dalen J, Ramsay G, Kootstra G. Group objective clinical examination in an inter-European accident and emergency course. Education for Health 1997;10:69-78.

60. Newble DI, Jaeger $K$. The effect of assessments and examinations on the learning of medical students. Medical Education 1983;17:165-71.

61. Frederiksen $\mathbb{N}$. The real test bias: Influences of testing on teaching and learning. American Psychologist 1984:39:193-202.

62. Gijselaers, WH. Kwaliteit van het onderwijs gemeten: Studies naar de betrouwbaarheid, validiteit en bruikbaarheid van studentoordelen. [Measuring quality of education: studies of reliability, validity and feasibility of student judgements] [Dissertation] Maastricht: University Press; 1988.

63. Dolmans DHMJ, Wolfhagen HAP, Schmidt HG, van der Vleuten CPM. A rating scale for tutor evaluation in a problem-based curriculum: validity and reliability. Medical Education 1994;28:550-8. 
64. Cook DA, Brown LM, Skakun EM. Factors which influence the outcome of student evaluation of teaching, in: Scherpbier AJJA, van der Vleuten CPM, Rethans J-J, van der Steeg AFW, editors. Advances in medical education, Dordrecht: Kluwer Academic Publishers; 1997.

65. van Dalen J, Eeckers P, Peerden M. Oordelen over simulatiepatiënten [Judgements about simulated patients]. In: Houtkoop E, Pols J, Pollemans MC, Scherpbier AJJA, Verwijnen GM, editors. Gezond Onderwijs-3. 's Gravenhage: Haagse Hogeschool; 1994.

66. Busari JO, Scherpbier AJJA, Boshuizen HPA. Comparative study of medical education as perceived by students at three Dutch Universities. Advances in Health Sciences Education 1997;1:141-51.

67. Blok GA, van Dalen J, Jager K, Ryan M, Wijnen R, Wight C, Morton JM, Morley M, Cohen B. The European Donor Hospital Education Programme (EDHEP): Addressing the training needs of doctors and nurses who break bad news, care for the bereaved, and request donation. Transplant International $1999 ; 12: 61-7$.

68. Rethans J-J. Needs assessment in continuing medical education through simulated patients. Journal of Continuing Medical Education in the Health Care Professions 1998;18:172-8. 


\title{
CHAPTER 2
}

\section{Factors influencing the effectiveness of communication skills training ${ }^{1}$}

\begin{abstract}
A Ithough more and more time and money are being spent on communication skills training, little is known about which factors influence the effectiveness of these programmes. The present study was conducted to shed sone light on this issue. Students perceptions of the learning effect of an extensive communication skills training progranme are assessed using a questionnaire, administered to two consecutive classes. Using learning effect reported by the students as dependent variable, contributions of yarious aspects of the programme to the learning effect were analysed.

The results show that more than half of the variance in the learning effect was explained by the content of the programme, with only $5 \%$ of the remaining variance being explained by the didactic skills of the teachers.
\end{abstract}

\section{INTRODUCTION}

Since the introduction of communication skills training into medical education many articles have described these programmes. ${ }^{1-7}$ A constant finding is that for communication skills training to be effective it must be continuous, with many longitudinal opportunities for students to practise and to receive feedback. 8.9

The traditional view is that learning frequently arises out of the student-teacher relationship. This would suggest that the student's perception of the teacher influences the teaching process. " Quirk and Letendre found that behavioural scientists achieved better results as teachers of communication skills than general practitioners in this teaching role. " This seems to contradict findings published by Lynch $e$ t al., who reported that students who had general practitioners as moderators scored significantly higher on communication skills than students who were trained by

\footnotetext{
'Published as: van Dalen I, van Hout JCHM, Wolfhagen HAP, Scherpbier AJJA, van der Vleuten CPM. Factors influencing the effectiveness of communication skills training: programme contents outweigh teachers' skills. Medical Teacher 1999;21:308-10.
} 
psychiatrist-teachers. ${ }^{10}$ These differences, however, were found to be attributable to procedural aspects of the course. Levine reported that generalists are more eager to teach history-taking and physical examination skills than specialists. "2 There is no conclusive evidence concerning the relationship between any of these aspects and a learning effect.

These findings are by no means conclusive or clear.

The present study was conducted to investigate which factors influence the students" perception of the effectiveness of an extensive communication skills training programme. The effect was investigated of the communication skills training programme at the University of Maastricht, which has been extensively described elsewhere. ${ }^{7}$

The four-year programme comprises four formats: communication skills training, (teacher-independent) simulated patient encounters, sessions in which students exchange feedback on their simulated patient encounters, and attitude-awareness sessions. The programme runs throughout the first four years of the medical curriculum. The first-year course is moderated by behavioural scientists, the second-year course by general practitioners, the third-year course by pairs of general practitioners and behavioural scientists and the fourth-year course by pairs of clinicians and behavioural scientists. $7,13.14$

\section{METHOD}

\section{Inst rument}

Student surveys have been shown to be valid and reliable instruments to evaluate a course ${ }^{15.16}$

The present study addresses three areas: the various components of the programme, teachers' didactic skills (distinguished by the different professional backgrounds) and learning effect. Students were asked to rate their agreement with statements on a five-point Likert scale, ranging from 1 (disagree completely) to 5 (agree completely).

\section{Subjects}

Questionnaires were completed by 771 medical students in the academic years 1992/1993 and 1993/1994. No difference was found between the results for the two academic years, whereupon these were combined. 


\section{Procedure}

The questionnaire was administered in the final session of the year. Students completed the questionnaire then and there. To reduce any potential effects of social desirability, the procedure ensured that the teachers did not see individual students' responses when the questionnaires were being completed. The questionnaire was mailed to the students who did not attend the final session.

\section{Statistical analyses}

Mean scores were calculated across items for each of the relevant areas. Descriptive statistics were calculated and a (stepwise) regression analysis was performed. The mean score for learning effect was used as the dependent variable, the other items of the questionnaire as independent variables.

\section{RESULTS}

An overall response of $72 \%$ was obtained with the distribution of the response being approximately equal across the academic years.

In general, the content of the programme, the teachers and the learning effect of the programme appear to be valued very highly by the students (table 1).

Table 1. Means, standard deviations and sample sizes for the answers by cluster (5point scale)

\begin{tabular}{llll}
\hline Cluster & mean & $\mathrm{SD}$ & $\mathrm{N}$ \\
\hline Content of the programme & 3.9 & 0.7 & 771 \\
Learning effect & 4.2 & 0.7 & 771 \\
Didactic skills of all teachers & 4.1 & 0.6 & 771 \\
- Didactic skills of general practitioner & 4.5 & 0.4 & 403 \\
- Didactic skills of behavioural scientist & 3.9 & 1.0 & 690 \\
- Didactic skills of clinician & 3.7 & 0.8 & 145 \\
\hline
\end{tabular}

\section{Contribution to learning effect}

In order to estimate the respective contributions of the different parts of the programme to the learning effect a (stepwise) regression analysis was performed (table 2). This showed that $37 \%$ of the variance in the learning effect was explained by the communication skills trainings. Of the remaining variance $14 \%$ was explained 
by attitude awareness sessions, $5 \%$ by the teachers" didactic skills and $3 \%$ by the feedback sessions following simulated patient encounters.

Table 2. Results of the stepwise multiple regression analysis of the learning effect, with the different parts of the programme as independent variables

\begin{tabular}{lcccc}
\hline Variable & $\mathrm{R}^{2}$ & Increase in $\mathrm{R}^{2}$ & $\mathrm{~F}$ & $p$ \\
\hline Communication skills training & 0.37 & 0.37 & 401.8 & 0.00 \\
Attitude awareness & 0.51 & 0.14 & 356.1 & 0.00 \\
Teachers didactic skills & 0.56 & 0.05 & 295.8 & 0.00 \\
Feedback on s.p. encounters & 0.59 & 0.03 & 245.0 & 0.00 \\
\hline
\end{tabular}

\section{Discussion}

The content of the programme contributed more than half of the variance in the reported learning effect whereas the didactic skills of the teachers contributed only $5 \%$. This may be explained by the fact that teachers have very little freedom to improvise in this highly structured programme.

Although the questionnaire was administered in such a way that the answers could not be seen by the teachers, student responses may reflect a certain degree of social desirability.

Fifty-nine percent of the variance in the learning effect (the dependent variable) was explained. A considerable proportion of the variance, i.e. $41 \%$, could not be attributed to these variables. The instrument used in this study relies on students' self-reports. The relation between these self-reports and more objective measures of communication skills is at best unclear. ${ }^{1720}$ We therefore recommend that further studies be conducted to assess the relationship between teachers' skills and professional backgrounds on the one hand and learning effects with respect to students' communication skills on the other hand. These studies should use other measuring instruments, such as teachers" judgements, (simulated) patients" judgements and OSCE results.

\section{LITERATURE}

1. Kahn GS, Cohen B, Jason $H$. The teaching of interpersonal skills in medical schools, Journal of Medical Education 1979;54:29-35. 
2. Sanson-Fisher R, Fairbairn S, Maguire P. Teaching skills in communication to medical students -a critical review of the methodology. Medical Education $1981: 15: 33-7$.

3. Monahan DJ, Grover PL, Kavey REW, Greenwald JL, Cook Jacobsen E, Weinberger $\mathrm{H}$ L. Evaluation of a communication skills course for second year medical students. Journal of Medical Education 1988;63:372-8.

4. Wells $\mathrm{K}$, Benson $\mathrm{M}$, Hoff $\mathrm{P}$. A model for teaching the brief psychosocial interview. Journal of Medical Education 1985;60:181-8.

5. Knox JD, Buchier IA. Communication skills teaching, learning and assessment, Medical Education 1985;19:285-9.

6. Hoppe RB, Farquhar LJ, Henry RC, Stoffelmayr BE, Helfer ME. A course component to teach interviewing skills in informing and motivating patients. Journal of Medical Education $\llbracket 988 ; 63: 176-80$.

7. van Dalen $\mathbf{J}$, Zuidweg J, Collet $\mathrm{J}$. The curriculum of communication skills at Maastricht medical school. Medical Education 1989;23:55-61.

8. Riccardi VM, Kurtz SM. Communication and counselling in health care. Springfield, Ill.: Charles C. Thomas; 1983.

9. Bowman FM, Goldberg DP, Millar T, Gask L, McGrath G. Improving the skills of established General Practitioners: the long term benefits of group teaching. Medical Education 1992;26:63-8.

1.0. Lynch DJ, Tamburino MB, Nagel $R$. Teaching interviewing skills: the effect of the instructors' academic department. Medical Teacher 1992;14:59-64.

11. Quirck M, Letendre A. Teaching communication skills to first-year medical students. Journal of Medical Education 1986;61:603-5.

12. Levine JH. Who will teach the skills of history taking and physical examination? Teaching and Learning in Medicine 1995;5:77-8.

13. van Dalen $\mathrm{J}$, Bartholomeus $\mathrm{P}$. Training clinical competence in a Skillslaboratory. In: Bender W, Hiemstra RJ, Scherpbier AJJA, Zwierstra RP, editors. Teaching and assessing clinical competence. Groningen: BoekWerk Publications; 1990. 
14. van Dalen $\mathbf{J}$. Teaching communication skills in the undergraduate curriculum. Medical Encounter. 1992;8:6-7.

15. Dolmans DHMJ, Wolfhagen HAP, Schmidt HG, van der Vleuten CPM. A rating scale for tutor evaluation in a problem-based curriculum: validity and reliabitity. Medical Education 1994;28:550-8.

16. Cook DA, Brown LM, Skakun EM. Factors which influence the outcome of student evaluation of teaching, in: Scherpbier AJJA, van der Vlleuten CPM, Rethans J-J, van der Steeg AFW, editors. Advances in medical education. Dordrecht: Kluwer Academic Publishers; 1997.

17. Gordon MJ. A review of the validity and accuracy of selfassessments un health professions training. Academic Medicine 1991;12:762-9.

18. Antonelli MAS. Accuracy of second-year medical students' self assessment in clinical skills. Academic Medicine 1997;72:S63-5.

19. Farnill D, Hayes SC, Todisco J. Interviewing skills: self-evaluation by medical students. Medical Education 1997;31:122-7.

20. Gruppen LD, Garcia J, Grum CM, Fitzgerald T, White CA, Dicken L, Sisson JC, Zweifler A. Medical students' self-assessment accuracy in communication skills. Academic Medicine 1997;72:557-9. 


\section{CHAPTER 3}

\section{Construct validity of the MAAS-Global ${ }^{1}$}

$\mathrm{T}$ his study investigates the construct validity of an instrument to measure the quality of communication skills, during one curriculum year of a four year longitudinal communication skills training programme. 42 Representative videotapes of students' simulated patient encounters at the beginning of the third year and 35 of the end of the year were assessed by nineteen trained observers, using the MAAS-Global criteria list. A difference in communication skill competence was found between the performance at the beginning and at the end of the third year. The specific aspects in which the students improved revealed a greater routine in conducting a doctor-patient encounter and a greater structuring capability: those communication skills that have been trained in the years before the study period, thus supporting the validity of this instrument.

\section{INTRODUCTION}

Communication skills are important qualities in the behaviour of a doctor. It has been shown that patient satisfaction and compliance are largely influenced by the quality of the communication between patient and doctor. ${ }^{1.2}$ Most medical curricula are therefore providing or preparing some form of teaching in communication skills. ${ }^{3}$ In the literature a multitude of teaching formats is described, directed at the acquisition of these skills. ${ }^{4.5}$ Research has shown that medical students tend to pay less attention to communication skills in the course of the curriculum; especially by the time they are to solve medical problems. ${ }^{6}$ In a medical curriculum it is therefore important to continuously focus on communication. ${ }^{7}$ Encounters with simulated patients is a format in which students can practise both the medical problem solving and the communication skills in an integrated way, yet without being distracted by the demands of a health care situation in which patients have other things on their minds than providing the optimal teaching facilities. ${ }^{8}$ When communication

\footnotetext{
'Published as; wan Dalen J. Prince CIAHI, Scherpbier AJJA, van der Vleuten CPM. Evallualing communication skills. Advances in Health Sciences Education 1998;3:187-95.
} 
skills are acquired under the conditions of continuation and integration they remain at the same level over a longer period, while some aspects of communication improve in time. 9.10

A continuous and integrated training has been realised in the communication skills training programme at the medical faculty of the University of Maastricht, The Netherlands. This programme is an important element of the first four curriculum years, embedded in a skills training programme in a specially designated Skillslab. 11. ${ }^{12}$ The overall curriculum takes six years, in the final two of which clinical rotations take place. The programme consists of a continuous alternation between in vitro" communication skills trainings and encounters with simulated patients, designed to practise these communication skills. The simulated patients play the same scenario for all students of a year group. The student usually takes the role of (locum of the) physician. In the second, third and fourth year the students perform entire doctor-patient encounters, including physical examination and advice. These encounters are recorded on videotape, and feedback is given. ${ }^{13}$

This programme takes place in the context of a problem based curriculum. An increase in communication skills of the students can be assumed for a number of reasons: teachers report progress in their students' communication skills; medical students ffom Maastricht feel themselves better prepared in psychosocial and interpersonal skills than students from more traditional faculties in The Netherlands, ${ }^{14}$ and it is claimed that students in a problem based curriculum further develop their ability to express themselves. ${ }^{15}$ Students' ratings of this programme are very positive. ${ }^{16}, 17$ The students also indicate that they perceive the programme as very effective. ${ }^{16}$

To assess the construct validity of an instrument to measure communication skills a study was conducted, attempting to answer the question whether this instrument actually shows student improvement. The hypothesis was tested that the instrument reveals better communication skills at the end of a curriculum year compared with the beginning of that year.

The training programme in the different year groups addresses different issues. In the first two curriculum years the focus of the programme is on exploratory behaviour: i.e. asking open ended questions and appropriate reflection of emotions. In the third year the students learn to better structure the consultation, to take a proper history by means of a directive interview and to explain findings to the patient (i.e. structuring, asking closed questions, consultation evaluation and providing information). Since this study focuses on the third year we expect the instrument to show improvement in elementary communication skills such as structuring, asking closed questions and providing information, whereas other communication skills would show no improvement. 


\section{METHOD}

\section{Subjects}

The third curriculum year was chosen because the students are by then fully accustomed to working with simulated patients. At the beginning of the third year sudents were asked to submit the videotape of their second simulated patient encounter and this request was repeated at the end of the third year for their last simulated patient encounter. Thirteen students submitted videotapes of both measurement 1 and 2, thus allowing only for a cross-sectional analysis. Sample 1 consisted of 42 recordings; sample 2 of 35 recordings. In total 77 recordings were available.

Consequently, a total group of 64 students participated in the study. To assess the representativeness of the samples of students with their peers in the total year group, achievement scores on a knowledge test were compared. These were not different. The marks of the thirteen students of whom two recordings were available did not differ from the marks of the other students, at any time.

\section{Instrument}

The instrument that was studied is the MAAS-Global, used in Maastricht to provide feedback on the students' communication skills. ${ }^{19-20}$ In this list thirteen caseindependent items are used, with a 7-point scale. Two types of items can be distinguished: items referring to communication skills needed in certain phases of the consultation (for example: exploring the patient's reason for the encounter, or: phrasing questions during history taking), and items about communicative behaviour needed in the entire consultation (for example: eliciting information, or: dealing with emotions). The focus of this instrument is on the process of communication, rather than the contents, i.e. how questions are plarased rather than what is asked. The instrument consists of a checklist and a 20-page scoring manual, listing criteria per item. The criteria are -as much as possible- operationalised as observable behaviour. In figure 1 an example of an item is given, with the criteria for scoring. Furthermore an overall global judgement about the whole consultation was given on a 10-point scale. A score of ' 5 " or lower is considered as insufficient on this scale (students failing the consultation), whereas a score of ${ }^{\prime} 6^{\prime}$ or higher is considered as a passing score. 
Item 10. Providing information

6543210 *

$\begin{array}{ll}\text { announces, categorises } & {[\text { II ] }} \\ \text { small quantities, concrete explanation } & {[\text { [I ] }} \\ \text { understandable language } & {[\text { II ] }} \\ \text { asks for understanding } & {[\text { [ ] ] }}\end{array}$

Criteria for "excellent":

The student announces that he will give information about a subject, and categorises the aspects that will follow.

The information is given in limited quantities and the student specifically clarifies details.

The language used is understandable and attuned to the patient.

The student checks wherher the information has come across to the patient, by asking directly.

Clarification of the criteria:

Example of announcement: "ll will first tell you what I have found, then what I think of and finally what can be done about it. First ..."

"Small quantities" indicates that the student does not give very much information at the same time. This can be achieved by inserting small breaks between bits of information, allowing the patient to react.

Students don"t often announce that they will give information, or categorise the information. They also don't often ask whether the patient understood what they have told. The mark on this item will therefore often be "good', 'sufficient" or lower. The inviting quality of the question is the most important aspect. If the question sounds paternalistic this is bound to be counterproductive, leading to a lower mark on this item.

Information is most likely to be given in the phases "evaluation and diagnosis" and "management and arrangements".

$* 6=$ excellent, $5=$ good, $4=$ sufficient, $3=$ doubtil, 2 =insufficient, $1=$ bad, $0=$ absent

Figure 1. Example of an item in the MAAS-Global

\section{Procedure}

Video recondings of regular simulated patient encounters were used. When the encounters were recorded the students wore unaware of the experiment. The videorecondings therefore show the students" natural behaviour. Directly after the simulated patient encounter the students received a letter asking permission to use the 
videotape for this study, after the tape had been used for review and feedback. Objections could be raised with the fourth-year student who superwised all encounters. On average all students had individually participated in ten simulated patient encounters previous to this study, and they had witnessed ten more as personal observers. Progress due to increased familiarity with the encounters during the study period is therefore highly unlikely.

In the third year itself, between the first and second measurement, the students took part in seven or eight more simulated patient encounters, reflecting a time interval of six to seven months.

The scenarios for the simulated patients at both measurements were highly comparable: on both occasions the complaint was chest pain. In the first situation this was caused by angina pectoris, in the second by pneumonia. The simulated patients were trained in a comparable way for both measurements. All simulated patients were equipped with a written scenario. Each simulated patient was individually instructed by a Skillslab staff member, focusing on realistic depiction of symptoms and simulation of findings with physical examination, as well as on personal characteristics and ideosyncracies.

Nineteen experienced skills trainers, familiar with the MAAS-Global were invited as raters. To enhance the reliability of the group-score, raters were maximally spread across tapes. In this way the group-score is the aggregate of nineteen different raters, and rater variance will hardly bias the results. The raters received oneand-a-half hour of training how to use the MAAS-Global. The raters were unaware of the purpose and the design of the study. Some raters were acquainted with the students but no one had been a teacher in that same year group.

\section{Statistical analyses}

The mean score of every student was calculated across the items of the MAASGlobal.

A one-way analysis of variance was used to test for a difference between both measurements, using general mark, mean score and separate items. Using the general mark pass/fail rates were calculated at both measurement points. To check which items in the MAAS-Global contributed most to the general mark on each moment of measurement, regression analyses were performed. 


\section{RESULTS}

In table 1 the mean scores are reported. Both the general mark (10-point scale) and the mean score (7-point scale) are significantly higher at the end of the third year than at the beginning of that year. An improvement is found for the following specific items: opening; exploring the reasons for encounter; eliciting information; providing information; (dealing with) emotions; empathy/flexibility.

Table 1. Differences of mean score, general mark and item scores on measurement 1 and measurement 2 (one way Anova)

\begin{tabular}{|c|c|c|c|c|}
\hline \multirow[t]{2}{*}{ variable } & \multicolumn{2}{|c|}{ beginning year $(\mathrm{N}=42)$} & \multicolumn{2}{|c|}{ end of year $(\mathrm{N}=35)$} \\
\hline & mean & $\mathrm{SD}$ & mean & $\mathrm{SD}$ \\
\hline $\begin{array}{l}\text { general mark } \\
\text { (10 pt. scale) }\end{array}$ & 5.40 & 1.55 & $6.50^{\prime}$ & 1.40 \\
\hline $\begin{array}{l}\text { mean score } \\
\text { (7 pt. scale) } \\
\text { items (7.pt. scale): }\end{array}$ & 3.02 & 0.84 & $3.62^{1}$ & 0.83 \\
\hline opening & 3.17 & 1.29 & $4.00^{1}$ & 0.84 \\
\hline exploring reason for encounter & 1.88 & 1.69 & 3.17 & 0.76 \\
\hline history taking & 3.26 & 1.48 & 3.69 & 1.45 \\
\hline physical examination & 3.57 & 1.55 & 3.65 & 1.91 \\
\hline evaluation and diagnosis & 3.52 & 1.13 & 3.91 & 1.08 \\
\hline management and arrangements & 3.60 & 1.13 & 3.45 & 1.03 \\
\hline consull evaluation & 2.15 & 1.70 & 2.91 & 1.73 \\
\hline eliciting information & 3.00 & 1.21 & $3.86^{1}$ & 1.00 \\
\hline providing information & 2.66 & 1.54 & $3.53^{\prime}$ & 1.38 \\
\hline emotions & 1.86 & 1.44 & $3.46^{1}$ & 1.40 \\
\hline summaries & 3.29 & 1.35 & 3.54 & 1.24 \\
\hline structuring & 3.60 & 0.99 & 3.62 & 1.33 \\
\hline empathy/tlexibility & 3.79 & 1.09 & $4.31^{1}$ & 0.96 \\
\hline
\end{tabular}

Table 2 shows the different ratios of passing/failing students at the two measurements. The percentage of students passing the insufficient mark of ' 5 ' is significantly increased at the end of the year. 
Table 2. Percentages of students passing and failing on measurement 1 and measurement 2 (Chi squared test).

\begin{tabular}{|c|c|c|}
\hline & beginning of year & end of year \\
\hline & $(\mathrm{N}=42)$ & $(N=35)$ \\
\hline Passed & 52 & $77^{1}$ \\
\hline Failed & 48 & $23^{1}$ \\
\hline
\end{tabular}

${ }^{\prime} p<.05$

The results of the regression analyses are reported in table 3 .

Table 3. Multiple regressions (stepwise) of the general mark with the different items of the MAAS-Global as independent variables, at different moments of measurement.

\begin{tabular}{|c|c|c|c|c|c|}
\hline Variable & $\mathrm{R}^{2}$ & $\begin{array}{c}\text { Increase } \\
\text { in } R^{2}\end{array}$ & df & $\mathrm{F}$ & $p$ \\
\hline & \multicolumn{4}{|c|}{ beginning of year } & \\
\hline empathy/flexibilicy & 0.58 & 0.58 & 37 & 51.1 & 0.00 \\
\hline management and arrangements & 0.71 & 0.13 & 36 & 44.9 & 0.00 \\
\hline opening & 0.78 & 0.07 & 35 & 40.6 & 0.00 \\
\hline eliciting information & 0.81 & 0.03 & 34 & 36.9 & 0.00 \\
\hline consultation evaluation & 0.84 & 0.03 & 33 & 34.6 & 0.00 \\
\hline history & 0.86 & 0.02 & 32 & 33.1 & 0.00 \\
\hline \multirow[t]{2}{*}{ exploring reasons for encounter } & 0.88 & 0.02 & 31 & 32.7 & 0.00 \\
\hline & \multicolumn{4}{|c|}{ end of year } & \\
\hline structuring & 0.50 & 0.50 & 28 & 27.9 & 0.00 \\
\hline consultation evaluation & 0.73 & 0.23 & 27 & 360 & 0.00 \\
\hline empathy/flexibility & 0.83 & 0.10 & 26 & 42.1 & 0.00 \\
\hline management and arrangements & 0.86 & 0.03 & 25 & 37.9 & 0.00 \\
\hline
\end{tabular}

On the first measurement $81 \%$ of the variance in the general mark is explained by the items 'empathy/flexibility', 'management and arrangements', 'opening" and 'eliciting information'. Those items reflect the topics of training in the first and 
second curriculum year. mainly exploratory behaviour. At measurement 2, at the end of the third year, $73 \%$ of the variance in the general mark is accounted for by the itoms "structuring", and "consultation evaluation". These items reflect the skills that are trained in the third year, a more directive approach.

\section{DIscussion}

A significant increase in communication skills was shown. as well as a significant incrase in the percentage of students passing the critical general mark of 5 on a 10 -point scale. This can be seen as support of the construct walidity of the instrument.

In giving a general mark at measurement 2 , the raters used the more "directive" communication skills, such as 'structuring' and 'consultation evaluation' to make a judgement. Apparently the exploratory skills were taken for granted, and the directive skills provided an extra positive weight in the eyes of the beholders. However, the results indicate that this behaviour has not entirely replaced the exploratory approach taught in the earlier years, judging from the $10 \%$ variance that is addilionally explained by the item 'empathy' at the second measurement.

These oútcomes should not be interpreted as supporting an increase in communication skills, but rather as supporting the construct validity of the instrument. The study was not dexigned to attribute any results to the communication skills programme: there was no control group to which these results were compared. The communication skills programme is provided to all students; it would have been too distuptive to withhold this programme for a group of students.

The use of one case limits the generalisability of these finding. It remains unknown to what extent differences in perceived difficulty of the cases have influenced the results. The contents of the scenarios were similar, but individual circumstances of the students (i.e. more or less familiarity with the contents of the case) may have diflered.

Due to uncontrollable circumstances, recordings of only thirteen students were avmilable from both the first and the last simulated patient encounter, thus limiting the possible analyses to comparisons a group level. Comparison of the the first and the last measurement of these thirteen students showed no significant difference on any of the variables (general mak, mean score, thirteen separate items or the passfall ratio); however, on all but three of these variables the last measurement had a higher value than the first. On wo items the second value was lower than the first ("physical examination' and 'management and atrangements") and on one item ("summaries') the value was exactly the same.

The global marks on the 10-point scale are low from an absolute perspective. This can be explained by the instruction given to the raters: the third-year students had 
to be rated according to the predefined criteria. These criteria represented the best possible communicative behaviour; apparently these are quite demanding.

Further study is needed to clarify how communication skills develop in a medicall school, either longitudinally, over a longer period of time or by using a control group within a shorter time frame.

\section{LITERATURE}

1. Aday LA, Anderson R. Development of indices of access to medical care. Ann Arbor, Michigan: Health Administration Press; 1975.

2. Hulka B, Cassel J, Kupper L, Burdette J. Communication, compliance and concordance between physicians and patients with prescribed medications. American Journal of Public Health 1966;66:847-53.

3. Evans BJ, Sweet B, Coman GJ. Behavioural assessment of the effectiveness of a communication programme for medical students. Medical Education 1993;27:34450.

4. Caroll JG, Monroe J. Teaching clinical interviewing in the health professions. A review of empirical research. Evaluation in the Health Professions 1984;3:21 45.

5. Monahan DJ, Grover PL, Kavey REW, Greenwald JL, Cook Jacobsen E, Weinberger $H L$. Evaluation of a communication skills course for second year medical students. Journal of Medical Education 1988;63:372-378.

6. Craigh JL. Retention of interviewing skills learned by first-year medical students: a longitudinal study. Medical Education 1992;26:276-81.

7. Flaherty JA. Education and evaluation of interpersonal skills. In: Rezler AG, Flaherty A, editors. The interpersonal dimension in medical education. New York: Springer Verlag; 1985.

8. Barrows HS. An overview of the uses of standardized patients for teaching and evaluating clinical skills. Academic Medicine 1993;63:443-53.

9. Alroy G, Ber R, Kramer D. An evaluation of the short-term effects of an interpersonal skills course. Medical Education 1984;18:85-9. 
10. Bowman FM, Goldberg DP, Millar T, Gask L, McGrath G. Improving the skills of established General Practitioners: the long term benefits of group teaching. Medical Education $1992 ; 26: 63-8$.

11. van Dalen J. Skillstab, a center for training of skils. In: van der Vleuten CPM, Wijnen W, editors. Problem based learning: perspectives from the Maastricht experience. Amsterdam: Thesis Publications; 1990.

12. van Dalen $J$, Bartholomeus $P$. Training clinical competence in a Skillslaboratory. In: Bender W, Hiemstra RJ, Scherpbier AJJA, Zwierstra RP, editors. Teaching and assessing clinical competence. Groningen: BoekWerk Publications; 1990.

13. van Dalen J, Zuidweg J, Collet J. The curriculum of communication skills at Maastricht medical school. Medical Education 1989:23:55-61.

14. Busari JO, Scherpbier AJIJA, Boshuizen HPA. Comparative study of medical education as perceived by students at three Dutch Universities. Advances in Health Sciences Education 1997;1:141-51.

15. Schmidt HG, Bouhuys PAJ. Onderwijs in taakgerichte groepen. [Teaching in task-oriented groups] Utrecht: Het Spectrum, 1980.

16. van Dalen J, van Hout JCHM, Wolfhagen HAP, Scherpbier AJJA. Factoren die van invloed zijn op de effectiviteit van praktisch medisch onderwijs [factors influencing the effectiveness of practical medical education]. In: ten Cate TJ, Dikkers HJ, Houtkoop $E_{3}$ Pollemans MC, Pols J, Smal JA, editors. Gezond Onderwijs-5. Houten: Bohn Stafleu Van Loghum; 1996.

17. van Hout JCHM, van Dalen J, Wolfhagen HAP. Praktisch medisch onderwijs in het basiscurriculum: studentenoordeel. PPractical medical education in the preclinical curriculum: student judgements In: Houtkoop E, Pols J, Pollemans MC, Scherpbier AJJA, Verwijnen GM, edilors. Gezond Onderwijs-3. 's Gravenhage: Haagse Hogeschool, 1994.

18. wan Thiel J, Kraan HF, van der Vleuten CPM. Reliability and feasibility of measuring medical interviewing skills: the revised Maastricht history taking and advice checklist. Medical Education 1991;25:224-9.

19. wan Thiel J, van der Vleuten CPM, Kraan HF. Assessment of medical interviewing skills: generalisability of scotes using successive MAAS-versions. In: Harden R. Hart I. Mulholland H. editors. Approaches to the assessment of clinical 
competence. Proceedings of the fifth Ottawa conference. Centre for medical education, University of Dundee: Scotland; 1992.

20. van Thiel J, van Dalen J. MAAS-Globaal criterialijst, versie voor de vaardigheidstoets Medisch Basiscurriculum. Maastricht: Universiteit Maastricht; 1995. 


\section{CHAPTER 4}

\section{Integrated assessment of communication skills ${ }^{1}$}

R eliability and validity of a concise global scale to assess communication skills, pared to a detailed measurement of communication skills and to the whole OSCE. A three-item scale, addressing key-elements of doctor-patient communication, was used in the OSCE in the final year of an undergraduate medical training programme. In every OSCE-station this respectful conduct scale (RCS) was completed by the examiner who also rated the student's clinical procedural skills. In two OSCE-stations communication skills were also assessed by a separate examiner using a detailed checklist: the MAAS-Global.

Reproducibility of the instruments, their combination and the other stations in the OSCE was estimated and extrapolated to a sample size of minimally acceptable reliability. The RCS was correlated with the MAAS-Global in the same station. The RCS-scores across other stations were correlated to the scores on these other stations and to the MAAS-Global.

Applying the RCS in clinical procedural stations, a generalisability of 0.80 requires 5.75 hours, considerably less than the MAAS-Global by itself or the whole OSCE (13.5 and 9.5 hours, respectively). The combination of the MAAS-Global and RCS-scores reaches a generalisability of 0.80 in 12.5 hours testing time. The RCS correlates 0.71 with the MAAS-Global in the same station. RCS scores across clinical procedural stations show a disattenuated correlation of 0.34 with the scores on the MAAS-Global in communication skills stations. Within stations, the RCS correlates 0.53 with clinical procedural skills performance. The RCS is a concise instrument, intended for integrated global assessment of communication skills in

\footnotetext{
submitted as: wan Dalen J. Hoogenboom RJI, Kerkhofs E, Scherpbier AJA, van der Vleuten CPM. Integrated assessment of communication skills in an OSCE using a concise global rating scale
} 
all patient encounters in an OSCE. The reproducibility is better than that of the overall OSCE. The instrument does not require additional examiners. It can easily be incorporated into an OSCE, acknowledging the relevance of doctor-patient communication in all patient encounters. However, when used by clinical examiners in stations with clinical procedural skills, its scores also reflect the students" performance of these clinical skills.

\section{INTRODUCTION}

Assessment of student achievements greatly influences students' learning behaviour: ${ }^{1.3}$ In Objective Structured Clinical Examinations (OSCE) ${ }^{7}$ students frequently display the kind of conduct which they expect to lead to high scores on the checklists. Checklists are also easily memorised, sometimes including typing errors, and flawlessly cited in the actual OSCE station. This type of behaviour is not what the station intends to measure: flexible skill performance, attuned to this particular patient and clinical context. This phenomenon is especially apparent when detailed checklists are used for the assessment of communication skills: students exhibit unusual, sometimes artificial behaviour while making sure that the examiner registers how they communicate. Occasionally, after an OSCE, students are heard to complain that in a station with a complex medical assignment they "had to communicate on top of that". In practice, doctors are unlikely to communicate just for the sake of communication. Doctor-patient communication is a vehicle to convey information, empathy and understanding. Communication skills should therefore not be assessed in isolation, irrespective of content. A more realistic assessment of communication skills is obtained if the assessment is integrated in the context of a doctor-patient encounter. In this way, assessment can focus on how communication takes place, as well as on what is being communicated.

Another requirement for the adequate assessment of communication skills is repeated measurement, even though reproducibility of the assessment of communication skills appears to be somewhat better than that of clinical procedural skills. 6.7 The most efficient measurement of communication skills has been reported by wan Thiel at al: a 45-minute OSCE with two examiners, or a 60-minute OSCE with one examiner yielded a generalisability coefficient of 0.80 , using a thirteen-item checklist, the MAAS-R2.

Finally, global ratings by experts have been proven to be a more appropriate measure of performance of clinical skills compared to detailed checklists. Global rating scales in OSCEs showed a higher inter-station reliability, better construct validity and better concurrent validity than checklists."

Taking these findings into consideration, we developed a three-item global rating scale for the assessment of communication skills: the respectul conduct scale 
(RCS). The scale is designed for usage in any OSCE-station in which students communicate with a patient.

To assess the reproducibility and validity of the RCS, the scale was administered in all stations of the OSCE in the final year of an undergraduate medical training programme. In this OSCE, cormmunication skills were separately measured in two stations, using the MAAS-Global. The MAAS-Global consists of 13 caseindependent items, the quality of which is to be rated on a 5-point scale (hence the extension 'global'). However, the items are operationalised in a 20 page instruction manual, detailing criteria for scoring. Application of the MAAS-Global requires extensive examiners' training.

The generalisability of the RCS, the MAAS-Global and their combination is estimated and compared to the reproducibility of the rest of the OSCE.

Content validity of the RCS has been addressed by the procedure by which the scale was developed. Convergent validity is expressed in the cortelation between the RCS and the MAAS-Global, designed to measure the same skills. The correlation between the RCS and the MAAS-Global assessed within the stations is expected to be high. Real convergent validity would be found in the correlation between the RCS-scores across all other stations and the MAAS-Global scores. This correlation will be reduced by the variation between stations. It is therefore expected to be lower than the previous correlation, but it should still be sizable. Divergent validity is expressed in a correlation between the RCS and the scores on all other stations, primarily designed to assess clinical procedural skills. This correlation is expected to be low, or at least lower than the previous correlation.

\section{METHOD}

\section{OSCE}

All students at the medical school of Maastricht. The Netherlands, are required to participate in an annual skills evaluation by means of an OSCE. This OSCE consists of a number of stations in which skills performance is assessed by trained examiners using checklists. ${ }^{10}$ Duration of the stations is variable, depending on the complexity of the skills assessed.

In the academic year 1999-2000, 180 students participated in the final year's OSCE. The OSCE consisted of eight standardised patient based stations, in which entire consultations were assessed. The total duration of this OSCE was two and a half hours, with six stations lasting 15 minutes and two stations lasting 30 minutes. In the latter two stations both clinical procedural skills and communication skills were assessed separately. The instmument used for the assessment of communication skills was the MAAS-Global. The MAAS-Global has been validated in several 
studies. ${ }^{8,11,12}$ For this experiment, in all stations (including the communication stations) the examiners completed the RCS in addition to the regular checklist. The examiners and the students were informed that the RCS would be used for research and formative purposes. An overview of the composition of this OSCE, with the examiners and the instruments used, is presented in figure 1.

\begin{tabular}{|c|c|c|c|}
\hline OSCE: & 6 (other) stations & $\&$ & 2 combination stations \\
\hline station time: & 15 minutes & & 30 minutes \\
\hline $\begin{array}{l}\text { content: } \\
\text { examiner: }\end{array}$ & $\begin{array}{l}\text { clinical procedures } \\
\text { physician }\end{array}$ & & $\begin{array}{l}\text { communication \& clin. procedures } \\
\text { behavioural } \\
\text { scientist }\end{array}$ \\
\hline instruments: & $\begin{array}{l}\text { checklist } \\
\text { RCS-other }\end{array}$ & & $\begin{array}{l}\text { MAAS-Global } \\
\text { RCS-com }\end{array}$ \\
\hline
\end{tabular}

Figure 1. Composition of $\mathrm{OSCE}$, with examiners and instruments involved.

\section{Instrument}

The RCS was developed by asking eight experts' opinions about items that were proposed by the first author. Representatives from the disciplines of general practice, surgery, and psychology were involved in this development. These experts also worked in the fields of medical education, skills teaching and/or skills assessment. Employing the 'Nominal Group technique', this panel validated the proposed items for covering the essential ellements of doctor-patient communication. They were also asked to judge the appropriateness of these items for the global assessment of the quality of communication. The scale would have to be used by examiners from a wide range of disciplines, untrained in assessing communication skills, and primarily focusing on students' clinical performance. The experts' comments and suggestions were accumulated. To avoid confusion, the scale wicth of the items was chosen to match the other scales used in the OSCE: ranging from 1 (poor) to 5 (good). A general mark was included, using a 10-point scale, ranging from 1 (poor) to 10 (excellent). The 10-point scale is the most common in The Netherlands for giving marks in any field. A ' 5 ' is considered as insufficient. The RCS is presented in figure 2. 


\begin{tabular}{lllllr}
\hline The student... & poor & \multicolumn{3}{c}{ good } \\
$\ldots$ shows respect & 1 & 2 & 3 & 4 & 5 \\
$\ldots$ is clear in communicating & 1 & 2 & 3 & 4 & 5 \\
Mark the overall quality of communication & & & & & \\
With the standardised patient $(1-10)$ : & & & $\ldots$ &
\end{tabular}

Figure 2. Respectful Conduct Scale

\section{Examiners}

In the two-day OSCE, 70 examiners are involved per day, from a wide variety of -primarily clinical- disciplines and rating experiences. A half-page of instructions for the RCS accompanied the regular examiners' instruction. There was no separate training in the use of the RCS.

\section{Statistical analyses}

For ease of comparison, the scores on the RCS items were each converted to a percentage scale ( 2 items were multiplied by 20 and 1 item by 10). The total RCS score was calculated as the mean of the three items. Means and standard deviations of the RCS scores were calculated for the stations in which communication skills were measured with the MAAS-Global, and across all OSCE-stations assessing clinical procedural skills ('other stations'). RCS scores were not available for all students due to incomplete data. In order to check representativeness, a T-test was conducted to compare the group of students whose RCS scores could be used to the group whose RCS scores could not be used. The MAAS-Global scores were converted to a percentage score, and descriptive statistics were calculated. Generalisability coefficients and standard errors of measurement (SEM) of the RCS, the MAAS-Global, the combination of RCS and MAAS-Global, and of the other stations of the OSCE were estimated, using a simple subjects by station general isability design.

RCS scores of the combined stations and RCS scores across all other stations were correlated with the results on the MAAS-Global. Because the RCS scores across the other stations are likelly to be influenced by the variation in content of these stations, the observed correlation was corrected for attenuation. RCS scores across all other stations were also correlated with the scores for clinical procedural skills on those stations. Neither the correlation between the RCS and the MAAS-Global within the same stations, nor the correlation between the RCS and the score for clinical procedural skills per station were corrected for attenuation since these comparisons concerned the same content. 


\section{REsuLTS}

Of 115 of the 180 students who took the sixth year OSCE complete RCS scores were available for the analyses. A T-test comparing the OSCE scores of the students who were and those who were not included in the calculations due to incomplete data, revealed no differences between these groups.

Descriptive statistics of percentage scores on all instruments used in the OSCE are presented in table 1.

Table 1. Descriptive statistics of percentage scores on all instruments (N students=115)

\begin{tabular}{lccl}
\hline & N stations & mean & SD \\
\hline RCS communication & 2 & 82.4 & 8.1 \\
MAAS-Global communication & 2 & 84.3 & 8.5 \\
RCS other stations & 6 & 83.5 & 5.5 \\
OSCE other stations & 6 & 84.2 & 5.9 \\
\hline
\end{tabular}

Generadisability coefficients and SEMS of the RCS, the MAAS-Global, the combination of the two instruments and of the rest of the OSCE are presented in table 2. To allow better comparison, these findings have been standardised to a one hour testing time and to an estimated sample of stations needed to reach a generalisability coefficient of 0.80 .

The RCS is the instrument with the best reproducibility, better than the OSCEscore, and substantially better than the MAAS-Global score. Using the RCS alone, 5.75 hours are needed to achieve a reproducible score for communication skills, less than the time needed for the whole OSCE to be reproducible. The SEM of the RCS is somewhat smaller than that of the whole OSCE. The combination of stations in which communication skills are assessed with the MAAS-Global checkllist and stations using the RCS reaches a generalisability of 0.80 with 12.5 hours testing time, one hour less than the time needed with the MAAS-Global alone. 
Table 2. Reproducibility (generalisability coefficients and Standard Errors of Measurement) of the respectul conduct scale used in stations assessing clinical procedural skills, in relation to the MAAS-Global and the rest of the OSCE, for the actual sample size used, standardised to one hour as well as to an estimated sample of stations needed to reach a generalisability coefficient of 0.80

\begin{tabular}{|c|c|c|c|c|}
\hline & $\begin{array}{l}\text { RCS } \\
\text { (other } \\
\text { stations) }\end{array}$ & $\begin{array}{l}\text { MAAS- } \\
\text { Global }\end{array}$ & $\begin{array}{l}\text { Combination } \\
\text { (RCS/MAAS-G) }\end{array}$ & $\begin{array}{l}\text { OSCE } \\
\text { (other } \\
\text { stations) }\end{array}$ \\
\hline \multicolumn{5}{|c|}{ Acrual sample size used: } \\
\hline n stations & 6 & 2 & 8 & 6 \\
\hline gen coeff & 0.51 & 0.23 & 0.48 & 0.39 \\
\hline SEM & 3.49 & 7.62 & 3.14 & 4.57 \\
\hline testing time (hours) & 1.5 & 1 & 2.5 & 1.5 \\
\hline \multicolumn{5}{|l|}{ I hour testing time: } \\
\hline n stations & 4 & 2 & $3^{*}$ & 4 \\
\hline gen coeff & 0.41 & 0.23 & 0.23 & 0.30 \\
\hline SEM & 4.27 & 7.62 & 5.43 & 5.59 \\
\hline \multicolumn{5}{|c|}{ Sample size needed for generalisability of 0.80 : } \\
\hline n stations & 23 & 27 & 40 & 30 \\
\hline SEM & 1.78 & 2.07 & 1.49 & 1.82 \\
\hline testing time (hours) & 5.75 & 13.5 & 12.5 & 9.5 \\
\hline
\end{tabular}

* the number of stations in 1 hour OSCE would be 3.2. For callculations this was rounded off to 3 .

The correlation-coefficients between the RCS-scores and the scores on the other instruments are shown in table 3 .

Table 3. Correlation of respectful conduct scale ( $\mathrm{N}$ students $=115$ )

\begin{tabular}{ll}
\hline RCS communication - MAAS-Global (same station) & $0.71^{1}$ \\
RCS across other stations - MAAS-Global & 0.05 \\
RCS across other stations - MAAS-Global (disattenuated) & 0.34 \\
RCS other stations - OSCE other stations & $0.53^{1}$ \\
\hline
\end{tabular}

correlation within stations, $p<0.01$ 
There is a considerable correlation $(0.71)$ between the RCS and the MAAS-Global in the same station. Correlation between the RCS (across other stations) and the MAAS-Global scores was lowest: 0.05 . This correlation is confounded by the variation between the different other stations. When corrected for attenuation, the correlation is 0.34 . The correlation between RCS and the scores for clinical procedural skills in the other stations is in between these rwo values: 0.53 .

\section{DISCUSSION}

The reproducibility of the $\mathrm{RCS}$ is better than that of the MAAS-Global. The time needed to reach a generalisable judgement with the RCS is still 5.75 hours, but much shorter than that for the rest of the OSCE. A simple instrument, the RCS, in all stations apparently delivers a substantially better reliability than an elaborate evaluation of communication on a few stations with the MAAS-Global (0.51 versus 0.23 ). With more OSCE stations this difference will be even more pronounced. It is possible that in this study we have used an OSCE with a coincidentally lower reproducibility. It might also be that reproducibility is attenuated by a ceiling effect. Overall, performance was quite good, with percentage scores over 80. This may háve caused relatively little discrimination between students. ${ }^{10}$

The three-item respectful conduct scale shows a high correlation with the MAASGlobal, designed to measure the same communication skills in the same stations. However, the correlation between RCS (other stations) and the MAAS-Global is close to zero: 0.05. Because this contrelation was calculated across stations, it was expected to be lower, influenced by variation in content. When corrected for this attenuation the correlation is 0.34 . This is still a lower value than that between the RCS and the content, within the other stations (clinical procedural skills), whereas it was expected to be higher. Logically, clinical content and communication are related to each other. However, it exceeds the relationship between different measures of communication (RCS and MAAS-Global) across different clinical contexts. Strong convergent validity would have been demonstrated when this was the reverse. The relationship between clinical context score and RCS communication score may also have been inflated by a halo-effect (i.e. the tendency to rate a person high on all aspects because he makes a good impression on one aspect).

From these findings it seems to be that, although the RCS is simple to administer and it has an adequate reproducibility, this instrument does not uniquely measure communication skills when administered in a station clinical procedural skills. This scale was presented as an add-on to the checklist for clinical procedural skills, involving primarily clinical examiners, untrained in assessing communication skills. The scores on this instrument seem also to reflect the exammers' judgements of clinical procedural skills, rather than the communication skills it was intended for. 
Apparently, with this instrument under these circumstances, assessing the clinical procedural performance together with the quality of communication is a complicated task. It would be interesting to investigate the RCS and its validity when separately assessed in each station by a separately trained expert examiner.

This study was conducted to assess the potential of an concise instrument for the integrated assessment of communication skills. We have shown that, with clinical examiners who also assess clinical procedural skills, this instrument is not as valid as we thought. However, the need for a reliable and valid instrument for the integrated assessment of communication skills is still present. In real practice, communication is an integral aspect of every doctor-patient encounter. Since OSCEstations should maximally resemble real practice, communication skills assessment ought to be represented in all OSCE stations. Further research into circumstances that would allow such integrated assessment of communication skills is recommended.

\section{LITERATURE}

1. Newble $D$, Jaeger $K$. The effect of assessments and examinations on the learning of medical students. Medical Education 1983;17:165-71.

2. Frederiksen $N$. The real test bias: Influences of testing on teaching and learning. American Psychologist 1984;39:193-202.

3. van der Vleuten CPM. The assessment of professional competence: developments, research and practical implications. Advances in Health Sciences Education 1996;1:41-67.

4. Harden RM, Gleeson F. Assessment of clinical competence using an objective structured clinical examination. Medical Education 1979;13:41-54

5. van Luijk SJ, van der Vleuten CPM, van Schelven RM. Observer and student opinions about skills tests. In: Bender W, Hiemstra RJ, Scherpbier AJJA, Zwierstra RP, editors. Teaching and assessing clinical competence. Groningen: BoekWerk Publications; 1990.

6. van der Vleuten CPM, Swanson DB. Practical strategies for improving the reproducibility of tests involving standardised patients. In: Bender W. Hiemstra RJ, Scherpbier AJJA, Zwierstra RP, editors. Teaching and assessing clinical competence. Groningen: BoekWerk Publications; 1990. 
7. van Thiel J, Kraan HF, van der Vleuten CPM. Reliability and feasibility of measuring medical interviewing skills: the revised Masstricht history taking and advice checllist. Medical Education 1991;25:224-9.

8. van Thiel $J_{*}$ van der Vleuten CPM, Kraan HF. Assessment of medical interviewing skills: generalisability of scores using successive MAAS-versions. In: Harden $\mathrm{R}$, Hart 1, Mulholland H, editors. Approaches to the assessment of clinical competence. Proceedings of the fifth Ottawa conference. Centre for medical education, University of Dundee: Scotland; 1992.

9. Regehr G, MacRae H, Reznick RK, Szalayn D. Comparing the psychometric properties of checklists and global rating scales for assessing performance on an OSCE-format examination. Academic Medicine 1998;73:993-7.

10. van der Vleuten CPM, van Luijk SJ, Swanson DB. Reliability (generalisability) of the Maastricht skills test. Proceedings of the Annual Conference on Research in Medical Education 1988;27:228-33.

11. var Daten J, Prince CJAH, Scherpbier AJJA, van der Vleuten CPM. Evaluating communication skills. Advances in Health Sciences Education 1998;3:187-95.

12. Ram P, van der Vleuten CPM, Rethans J-J, Grol R, Aretz K. Assessment of practising family physicians: comparison of observation in a multiple station examination using standardised patients with observation of consultations in daily practice. Academic Medicine 1999;74:62-9.

13. Colliver IA, Swartz MH, Robbs RS, Cohen DS. Relationship between clinical competence and interpersonal and communication skills in standardised patient assessment. Academic Medicine 1999;74:271-4.

14. Cook TD, Campbell DT. Quasi-experimentation. Design and analysis issues for fields settings. Boston: Houghton Mifflin; 1979. 


\section{CHAPTER 5}

\section{Predicting communication skills with a paper-and-pencil test ${ }^{1}$}

$\mathrm{T}$ his study is conducted to investigate the value of a written knowledge rest of communication skils for predicting scores on a performance test of communcation skills.

A paper-and-pencil test of knowledge about communication skills and a performance test of communication skills, consisting of four stations wilh standardised patients, were administered to students of two year groups of the medical schools of Maastricht and Leiden, The Netherlands. The results on the se tes ts were compared. The year group of the participating students could be predicted about equally by both instruments. $60 \%$ correct qualifications by the knowledge test and $64 \%$ by the multiple station examination. Between the two lests an overall, disattenuated correlation of 0.60 was found $(\mathrm{N}=133, p<0.01)$, suggesting moderate predictive value of the knowledge test for the performanee test of communication skills. The correlation is stronget for students from Maastricht medical school than lor their colleagues in Leiden. Correlation between the knowledge about communication skills test and other avallable test results of the participating Maastricht students is close 10 zero, suggesting that the test measures a distinct quality of students competence:

The paper and pencil test of knowledge about communication skills has predictive value for the performance of these skills, but this value seems to be less pronounced than similar findings for clinical procedural skills. The stronger relationship between 'knowing how' and showing' in the Maastricht student group night be indicative of an effect of the training format:

\footnotetext{
'Accepted for publication in Medical Education as: wan Dalen J, Kerkhofs $\mathbb{E}$, Verwijnen $G M$, van Knippenberg wan den Berg BW, van den Hout HA, Scherpbier AJA, van der Vleuten CPM. Predicting communication skils with a paper-and-pencil test.
} 


\section{INTRODUCTION}

Skills assessment in medical schools relies heavily on multiple station examinations. ${ }^{1-3}$ Patrick has argued that a relationship exists between knowledge about, and competence in skills. ${ }^{\text {"S }}$ Several studies have addressed the predictive value of tests of knowledge about skills, for performance tests of skills. Newble ef al., and van der Vleuten et al. reported a high correlation between knowledge of clinical procedural skills and actual skill performance. 5.6 Van der Vleuten et al. reported that the correlation between performance tests and paper-and-pencil knowledge tests of skills increased from $r=0.04$ in the first year of medical school to $r=0.89$ in the final year. ${ }^{6}$ The knowledge test demonstrated differences in ability level and showed subtle changes in score patterns over items across years of training, indicating its construct validity. They concluded that a knowledge test of skills can predict scores on a performance test. A knowledge test can be used as supplementary information to performance testing and it is an efficient alternative for progress evaluation. ${ }^{7}$ In the first Dutch inter-curricular comparison of knowledge about skills and skill performance, Scherpbier found a correlation of 0.86 between a written test and an Objective Structured Clinical Examination (OSCE). ${ }^{8}$ Janssen found a correlation of 0.54 in a study of General Practitioners, and Remmen, who compared medical schools in Belgium and the Netherlands, found correlation coefficients between 0.64 and 0.85 ., 10

The high correlation between a paper-and-pencil knowledge test of skills and a performance test of these skills has been demonstrated for a large variety of clinical procedural skills. In the acquisition of clinical procedural skills, cognitive factors play an important role. In addition to the technically correct performance of the procedure, students must know what the indications are and how to interpret the findings. Moreover, the acquisition of these skills does not take place until medical school.

The acquisition of communication skills may follow different rules, however. Students have been communicating all their lives. More or less stable communication styles may already have been established when they enter medical school. Professional communication is firmly embedded in a cognitive basis but personality factors are more likely to play a role in the acquisition of these skills, compared to clinical procedural skills. ${ }^{11.12}$ This may explain why communication skills assessment suffers less from case specificity than the measurement of clinical procedural skills. ${ }^{13-17}$ It is therefore not certain whether a strong relationship between knowledge and performance of clinical procedural skills can be extrapolated to communication skills. It is likely that a relation between knowledge about communication skills and the quality of the communication itself will be weaker.

In this study we investigated whether scores on a knowledge test of communication skills can predict the scores on a multiple station examination of communication 
skills. We expect the correlation between the two tests to be somewhat lower than the correlation reported between knowledge and performance of clinical procedura! skills. The two tests were administered to students of two classes of two medical schools in the Netherlands. In order to judge divergent validity, comparisons were made with the results of the participating Maastricht students on other avaltable instruments, i.e. the Maastricht Progress Test of medical knowledge in general and the annual Maastricht OSCE. consisting of a range of skills. $3,18,19$ The instruments. under investigation are intended to measure a specific aspect of medical competence, ii.e. communication skills. The relationship between the paper-and-pencil test and the multiple station examination of communication skills on the one hand, and the progress test and the OSCE of medical competence in general on the other hand, is therefore expected to be low.

\section{METHOD}

\section{Subjects}

The study sample consisted of 133 students from the medical schools of Maastricht and Leiden in The Netherlands. The Maastricht curriculum is problem based with emphasis on small group sessions. ${ }^{20}$ Skills are acquired in a longitudinal, integrated skills training programme in the Skillslab. ${ }^{21-23}$ Leiden medical school is characterised by a more traditional, primarily lecture-based curriculum with concentrated skills training at some points in the curriculam. ${ }^{24}$

To save on resources students were tested at crucial points in both curricula: at the beginning of the clinical period and at the end of the final (sixtly) year. At the end of the fourth year the Maastricht students have completed their pre-clinical skills training programme in the Skillslab, while their Leiden colleagues at the beginting of the fifth year have completed the introduction to clinical medicine course, the ALCO-programme. At the end of the sixth year all students approached the end of the curriculum.

The Maastricht students were volunteers. Their marks on the annual OSCE (skills test), however, showed no significant difference at the $p<0.01$ level with those of the other students of their year group. The participating Maastricht students can therefore be considered to be representative of their year groups. In Leiden, data about the representativeness of the participating students for the whole year group were lacking. However, random sampling may be assumed since students scheduled for certain teaching activities between March and June 1999 took these fests, for formative purposes only. 


\section{Instruments}

The paper-and-pencil test consists of 78 items addressing knowledge about com munication skills (KCS). The content of the items is based upon findings from the jiterature. As much as possible, the items measure applied knowledge, i.e. which intervention is preferred over alternatives in a certain situation. The items were selected from an existing pool of about 18,000 items for the assessment of knowledge in the medical school at Maastricht. The procedure by which the production of these items is guided has been documented. ${ }^{25}$ The items have the format of a stem or a vignette with one or more statement(s). The students indicate whether a statement is correct or incorrect or they can choose the "I don"t know" option, a question mark. All phases of the medical consultation are represented in the test, as well as knowledge about the structure of the whole consultation. The test score is expressed as the correct-minus-incorrect score. An example of two test items can be found in figure 1 .

To help a frightened patient to expand on his complaints, certain communication skills are more adequate than others. Assuming that the following interventions are given in an understanding tone of woice, in the majority of cases:

"In reality it is often not so bad..." is better than:

"It frightens you, doesn't it?"

"What is it that frightens you?" is better than:

true /? / false

"I have experienced something similar..."

true /? / false

Figure 1. Example of one stem with two items of the paper-and-pencil test of knowledge about communication skills (KCS)

The multiple station examination (MSE) consists of four 15 minute stations in which students perform an entire consultation with a standardised patient with live observation by traned raters. Based on earlier data, a combination of four stations was considered sufficient for a generalisable judgement. ${ }^{1.5}$ The standardised patient cases are listed in figure 2.

The instrument used in the multiple station examination is the MAAS-Global. It consists of a checklist and a 20 -page scoring manual, listing criteria per item. In the checklist twelve case-independent items are used, to be rated on a 6-point scale. The focus of this instrument is on the communication process, rather than the content, i.e. how questions are asked rather than what is asked. As much as possible the criteria have been operationalised as observable behaviour. The MAAS-Gilobal has been validated in several studies. 


\begin{tabular}{|c|c|c|c|c|}
\hline gender & age & setting & diagnosis & communication skills \\
\hline $\operatorname{man}$ & 45 & GiP & iliotibial friction syndrome & problem clarification \\
\hline woman & 58 & GP & hypothyroidism & history, explanation \\
\hline woman & 32 & Obstetrics & $\begin{array}{l}\text { pregnancy with } \\
\text { high blood pressure }\end{array}$ & negotiation \\
\hline man & 62 & $\begin{array}{l}\text { Intemal } \\
\text { Medioine }\end{array}$ & $\begin{array}{l}\text { reduced foetal development } \\
\text { adenocarcinoma } \\
\text { of the prostate }\end{array}$ & breaking bad news \\
\hline
\end{tabular}

Figure 2. Cases in the multiple station examination (MSE)

To control for a possible 'priming' effect of one instrument for the other, the students were randomly assigned to the order in which they participated in the two measurements: half of the students first completed the paper-and-pencil test and then the multiple station examination, for the other half this order was reversed.

\section{Statistical analyses}

The correct-minus-incorrect scores on the KCS were converted to a percentage scale. The marks received on the MSE were expressed as a percentage of the maximum score per station and averaged across stations. Descriptive statistics were calculated, as well as Cronbach"s alphas of both instruments. Discriminant analysis was performed with the KCS and the MSE, respectively, as independent variables and year group as dependent variable. Pearson correlation was calculated and corrected for attenuation caused by unreliability of tests, as this unreliability tends to obscure existing relations between scores. Disattenuated correlation is indicative of the correlation that would result if the tests had perfect reliabilities. ${ }^{28}$

\section{RESULTS}

There was no systematic difference in the results of the students who first participated in the KCS and then in the MSE, compared to those for whom this order was reversed. Therefore these groups were subsequently considered to be similar. Discriminant analysis revealed that between $54 \%$ (Maastricht) and $67 \%$ (Leiden) of the year group of the students were correctly classified by the KCS; $60 \%$ in total. Between $65 \%$ (Maastricht) and $62 \%$ (Leiden) could be correctly classified by the MSE; $64 \%$ in total.

Descriptive statistics of the participating groups are presented in table 1 . 
Table 1. Descriptive statistics of the percentage scores on KCS and MSE

\begin{tabular}{lccccc}
\hline & \multicolumn{2}{c}{ KCS } & \multicolumn{2}{c}{ MSE } & \multirow{2}{*}{ N } \\
& mean & SD & mean & SD & N \\
\hline Maastricht & 58.6 & 10.2 & 68.8 & 5.9 & 76 \\
Leiden & 52.1 & 15.0 & 59.7 & 6.7 & 57 \\
Total & 55.8 & 12.8 & 64.9 & 7.7 & 133 \\
\hline
\end{tabular}

Table 2 shows that the observed correlation in both medical schools combined was $0.33(\mathrm{~N}=133, p<0.01)$. The disattenuated overall correlation between 'knowing about' and 'showing' is 0.60 . Cronbach's alphas of both instruments are low and varied.

Table 2. Observed and disattenuated correlation between the scores on KCS and MSE

\begin{tabular}{lrllll}
\hline & N & $\begin{array}{l}\text { observed } \\
\text { comelation }\end{array}$ & $\begin{array}{l}\text { alpha } \\
\text { KCS }\end{array}$ & $\begin{array}{l}\text { alpha } \\
\text { MSE }\end{array}$ & $\begin{array}{l}\text { disattenuated } \\
\text { correlation }\end{array}$ \\
\hline Maastricht & 76 & $0.28^{1}$ & 0.41 & 0.25 & 0.88 \\
Leiden & 57 & 0.20 & 0.72 & 0.24 & 0.48 \\
Total & 133 & $0.33^{1}$ & 0.62 & 0.49 & 0.60 \\
\hline
\end{tabular}

$p<0.01$

If the results are regarded separately for the two participating medical schools, the correlation in Maastricht is $0.28(\mathrm{~N}=76, p<0.01)$. Corrected for attenuation the correlation is: 0.88 . In Leiden the observed correlation is $0.20(\mathrm{~N}=57$, NS) and the disattenuated correlation is 0.48 .

The cortelation of the instruments used in this study with other available test results of the Maastricht students is given in Table 3. Comparison is made with the Progress Test, a test of general medical knowledge, and with the annual OSCE, consisting of a wide variety of skills.

The correlation between the KCS and the MSE is significant (observed: 0.28 , corrected: 0.88 ). The correlation between the KCS and measures of students ${ }^{*}$ general medical knowledge, and the OSCE are close to zero, both observed and corrected for attenuation. Correlation between medical knowledge in general and the OSCE is considerably higher: 0.45 observed and 0.69 when corrected for attenuation. 
Table 3. Observed (lower triangle) and disattenuated (upper triangle) correlation of KCS and MSE with general medical knowledge (Progress Test) and general medical skills performance (OSCE)

\begin{tabular}{lcllrl}
\hline & KCS & MSE & Progress Test & OSCE & N \\
\hline KCS & 1 & 0.88 & 0.03 & -0.07 & 76 \\
MSE & $0.28^{1}$ & 1 & 0.10 & 0.07 & 76 \\
Progress Test & 0.02 & 0.06 & 1 & 0.69 & 76 \\
OSCE & -0.04 & 0.04 & $0.45^{1}$ & 1 & \\
\hline
\end{tabular}

${ }^{1} p<0.01$

\section{DISCUSSION}

In this study a modest correlation is found between a paper-and-pencil test of knowledge about communication skills (KCS) and a multiple station examination of the performance of communication skills (MSE). As expected, this correlation is lower than reported correlation between knowledge about clinical procedural skills and the performance of those skills.

The correlation of the KCS and the MSE with measures of students' general medical knowledge or general skills performance is close to zero. This suggests that the $\mathbb{K C S}$ and the MSE measure a unique aspect of students' competence, their communication skills. With either instrument more than half of the students' year groups could be correctly classified. This relatively low proportion suggests that communication skills are to a certain extent acquired before students enter medical school. Progress in these skills during medical school can therefore only be limited. Furthermore, communication skills have been shown to improve when training takes place, ${ }^{26}$ and in the period studied some systematic training takes place in Leiden and none in Maastricht.

The reliabilities of the paper-and-pencil test and the multiple station examination are low in some cases, lower than those reported by van Thel et al. ${ }^{15}$ When the instruments are used to draw conclusions at individual level, greater test lengths will be necessary. The observed correlation between the two instruments is not high. However, if the instruments had perfect reliability, the correlation would be more substantial.

The correlation is mainly accounted for by students from the medical school at Maastricht and less so in Leiden. This could be attributable to differences in educational format. An integrated approach to leaching, as in the PBL pre clinical curriculum with a Skillslab at Maastricht might result in a higher correlation between knowledge and performance. In Maastricht communication skills training is organ- 
ised longitudinally, with students and teachers meeting once every two weeks, while the students participate in teacher-independent simulated patient encounters in between. The cases portrayed by the simulated patients are relevant to the themes of the tutorial sessions in the problem based tutorial groups. It is likely that this organisational link enhances the integration of knowledge and skills.

From this study it may be concluded that the paper and pencil test of knowledge about communication skills has some predictive value for the performance of these skills. However, this value is less pronounced than the predictive value of a knowledge test for the performance of clinical procedural skills. Apparently, communication skills follow different rules. Further study into the difference between communication skills and clinical procedural skills and the implication of this difference for teaching and assessment is therefore strongly recommended.

\section{LITERA TURE}

1. Harden RM, Gleeson F. Assessment of clintcal competence using an abjective structured clinical examination. Medical Education 1979;13:41-54.

2. Stillman PL, Swanson DB. Ensuring the clinical competence of medical school graduates through standardised patients. Archives of Internal Medicine $1987 ; 147: 1049-52$.

3. van Luijk SI. Al doende leert men [Learning by doing] [Dissertation] Maastricht: University Press; 1994.

4. Patrick J. Training: research and practice. London: Academic Press; 1992.

5. Newble DI, Swanson DB. Psychometric characteristics of the objective structured clinical examination. Medical Education 1988:23:325-34.

6. van der Vleuten CPM, van Luijk SJ, Beckers H.M. A written test as an alternative to performance testing. Medical Education 1989,23:97-107.

7. Verhoeven BH, Hamers JGHC, Scherpbier AJJA, Hoogenboom RJI, wan der Vleuten CPM. The effect on reliability of adding a separate written assessment component to an objective structured climical examination. Medical Education $2000 ; 34: 525-9$ 
8. Scherpbier A.JA. Kwaliteit van vaardigheidsonderwijs gemeten. [Measuring quality of skills training] [Dissertation] Maastricht: University Press; 1997.

9. Janssen JJM, Tan LHC, van der Vleuten CPM, van Luijk SJ, Rethans J-J, Grol RPTM. Assessment of competence in technical clinical skills of general practitioners. Medical Education 1995;29:247-53.

10. Remmen R. Scherpbier AJJA, Derese A, Denekens J, Hermann I, Hoogenboom $R$, van der Vleuten $C$, van Royen P, Bossaert L. Correlation of a written test of skills and a performance based test: validation study in two traditional schools. Medical Teacher 2001;23:29-32.

11. Kurtz S, Silverman J, Draper J. Teaching and learning communication skills in medicine. Oxon: Radcliffe Medical Press; 1998.

12. Silverman J, Kurtz S, Draper J. Skills for communicating with patients. Oxon: Radcliffe Medical Press; 1998.

13. van der Vleuten CPM, Swanson DB. Practical strategies for improving the reproducibility of tests involving standardised patients. In: Bender W, Hiemstra RJ, Scherpbier AJJA, Zwierstra RP, editors. Teaching and assessing clinical competence. Groningen: BoekWerk Publications; 1990.

14. van Thiel J, Kraan HF, van der Vleuten CPM. Reliability and feasibility of measuring medical interviewing skills: the revised Maastricht history taking and advice checklist. Medical Education 1991;25:224-9.

15. van Thiel J, van der Vleuten CPM, Kraan HF. Assessment of medical interviewing skills: generalisability of scores using successive MAAS-versions. In: Harden R, Hart I, Mulholland H, editors. Approaches to the assessment of clinical competence. Proceedings of the fifth Ottawa conference. University of Dundee, Scotland: Centre for medical education; 1992.

16. van der Vleuten CPM. The assessment of professional competence: developments, research and practical implications. Advances in Health Sciences Education $1996 ; 1: 41-67$.

17. Bögels SM, Teaching and assessing diagnostic interviewing skills, an application to the mental health field. [Dissertation] Maastricht: University Press; 1994 
18. van der Vleuten CPM, Verwijnen GM, Wijnen WHFW. Fifteen years of experience with progress testing in a problem-based curriculum. Medical Teacher $1996: 28: 103-9$.

19. van der Vleuten CPM, van Luijk SJ, Swanson DB. Reliability (generalisability) of the Matastricht skills test. Proceedings of the 27th Annual Conference on Research in Medical Education. Chicago: AAMC; 1988.

20. van der Vleuten CPM, Scherpbier AJJA, Wijnen WHFW, Snellen HAM. Flexibility in learning: a case-report on problem based learning. International Higher Education 1996;2:17-24.

21. van Dalen $J$, Zuidweg $J$, Collet J. The curriculum of communication skills at Maastricht medical school. Medical Education 1989;23:55-61.

22. van Dalen J, editor. Skillslab, centre for training of skills, Maastricht: University Press; 2000.

23. van ,Dalen J, Bartholomeus P, Kerkhofs E, Lulofs R, van Thiel J, Rethans J-J, Scherpbier AIJA, van der Vleuten CPM. Teaching and assessing communication skills in Maastricht: the first twenty years. Medical Teacher 2001;23:245-51.

24. Studiegids Geneeskunde. Curriculum 1998-1999. Dienst onderwijs-en studentenzaken, Faculteit der Geneeskunde, Rijksuniversiteit Leiden. [Study guide Faculty of Medicine, University of Leiden]

25. Verhoeven BH, Verwijnen GM, Scherpbier AlJA, Schuwirth LWT, van der Vleuten CPM. Quality assurance in test construction: the approach of a multidisciplinary central test-committe. Education for Health 1998:12:49-60.

26. van Dalen J, Prince CJAH. Scherpbier AJJA, van der Vleuten CPM. Evaluating communication skills. Advances in Health Sciences Education 1998:3:187-95.

27. Ram P, wan der Vleuten CPM, Rethans J-J, Grol R, Aretz K. Assessment of practising family physicians: comparison of observation in a multiple station examination using standardised patients with observation of consultations in dally practice. Academic Medicine 1999;74:62-69.

28. Gunford JP. Fruchter B. Fundamental stavistics in psychology and education. London: McGraw-Hill, Inc; 1973. 


\section{CHAPTER 6}

\section{Longitudinal and concentrated communication skills programmes compared $^{1}$}

$\mathrm{T}$

he communication skils of students of the Dutch medical sehools of Marstricht and Leiden were compared, to assess the effectuveness of these schools differ ent approaches to communication skills traning. Both schools have a six-year un dergraduate medical curriculum, divided into four prechinical yeans and wo years of clinical clerkshps. The Maastricht problem-based curriculum offers an integrated clinical skills training programme, including communication skills, which runs throughout the first four years. Communication skills traning in Leiden is concentrated in courses in the preclinical phase, at the beginning of the clinical phase and preceding two clerkships.

Communication skills of fourth-year and sixth-year students $(\mathrm{N}=161)$ of both onversities were assessed using four OSCE stations in which students did entire con sultations with standardised patients. Tramed observers rated these consultations. using a checklist.

Maastricht students of both year groups obtaned significandy higher cheoklast scores for their communication skills than their Leiden colleggues. The Leiden students" scores increase between years 4 and 6 , wheteas those of the Maasurcht stu dents showed no significant change.

The higher scores obtained by the Maastricht students indicate a greater overall effectiveness of a longitudinal, integrated approach compared with concentrated courses. Absence of formal training in the clinical phase in Mastricht leads to slat bilisation of communication skills, whereas the increase in the Leiden students" scores between years 4 and 6 offers evidence that fonal communication skils training during the clinical phase does pay off. These frndings suggest that the pre-

\footnotetext{
'Accepted for publication in Advances in Health Sciences Education as: van Dalen J, Kenkhofs E, van Knippenberg-van den Berg BW, van den Hout HA, Scherpbier AJA, van der Vleuten CPM. Longitudinal and concenirated communication skils programmes: iwo Dutch medical schools compared.
} 
ferred approach to communication kills training would be an integrated, longitudinal programme, which contimues during the clinical years.

\section{INTRODUCTION}

More and more attention has been paid to communication skills training in medical education during the past twenty years. Numerous different approaches have been described and studied and guidelines for communication skills training were developed and published. ${ }^{1-10}$ It has been demonstrated that medical students" communication skills deteriorate if no formal training is provided. ${ }^{11.12}$ Because training is most effective when students perceive and acknowledge a need to improve their skills, Aspregren recommended that communication skills be taught during the clinical phase of the curriculum when students have to apply these skills in contacts with real patients. "It has, however, also been argued that training should be continuous rather than concentrated, with opportunities for students to refresh and expand skills learned earlier in the course. ${ }^{8,13-19}$ These two recommendations, i.e. to adopt a concentrated or a longitudinal approach to training, seem to be contradictory.

The vast majority of studies address the results of concentrated training programmes. ${ }^{2,7-10}$ It would be helpfull for course designers when studies of the effectiveness of communication skills training took account of the programmes" curricular contexts. This would shed more light on the question what works under which circumstances and what does not work.

In light of the preceding, we decided to compare the communication skills of students in two different educational programmes. We selected the medical schools of Maastricht and Leiden, because the most recent survey of communication skills training at Dutch medical schools found that the most marked differences between training progtammes were found between these two schools. ${ }^{20}$

The communication skills programmes of these schools are comparable in some ways. They have similar learning objectives, the overall amounts of time devoted to formal instruction and practising of communication skills are not very different, and the programmes use similar teaching materials and training formats, such as role play, exercises and simullated patient encounters followed by feedback. The differences between the schools are found in the overall curricular approach and in the way communication skils training is scheduled in the curriculum. Communication skills training in Mastricht is part of the systematic, integrated. longitudinal skills training programme of the Skillslab in the four preclinical years. ${ }^{21.22}$.This programme is characterised by a helical approach: students practise relevant communication skil]s in a continuous altemation of exercises, role play and simulated patient encounters with feedback. Groups of ten students, which remain in the 
same composition for one year, meet once every two weeks with one or two teachers. ${ }^{5.23}$ No systematic skills training takes place in the two clinical years in the last phase of the curriculum. In Leiden, the communication skills training programme consists of three stages: two concentrated courses in the preclinical years, a fiveweek full-time skills training programme as an introduction to clinical medicine (ALCO) at the beginning of the clinical phase and two concentrated training courses preceding two clerkships. In both schools, the clinical clerkships during years 5 and 6 consist of similar rotations through hospital departments.

Further instructional differences can be summarised as follows: the Maastricht curriculum is based on the Problem Based Learning (PBL) model with emphasis on small group sessions, whereas Leiden medical school, at the time of this study, was characterised by a more traditional, primarily lecture-based curriculum. ${ }^{24,25}$ Leiden students participate in a formal introductory course to the clinical clerkships and Maastricht students receive no such introduction. Claims have been made that PBL promotes competence in general communication skills, although its effect on doctor-patient communication has not systematically been studied. ${ }^{26}$ We assume that there is no systematic effect of either of the two curricula on the students' skills in communicating with patients.

In order to determine whether the differences between longitudinal skills training and concentrated skills courses would be reflected in students' communication skills, we compared the results of students from Maastricht and Leiden on a specifically designed and administered multiple station examination.

\section{METHOD}

Communication skills are most often assessed by means of some form of multiple station examination. Students' ability to communicate with standardised patients is directly observed. This setting is as close as possible to real life as it is in the context of situations or problems that students will encounter in real medical practice. Because a multiple station examination is an expensive procedure, only students at crucial points in both curricula were tested. In Mastricht these crucial points were: the end of the fourth year, when students had completed the Skillslab training programme and were about to move on to the clinical clerkships, and at the end of the final (sixth) year. In Leiden the students were tested before the beginning of the ALCO-programme (pre-ALCO group), immediately following this programme (post-ALCO group, just before their clerkships) and at the end of the final (sixth) year. 


\section{Subjects}

Maastricht:

The Maastricht fourth-year students received a written and a verbal invitation, explaining the experiment and mentioning a small financial compensation. Enough students volunteered for the available 40 places. Two dropped out. Recruitment of the Maastricht sixth-year students was similar. Because only 18 volunteers were recruited, another test was organised in the first week of the General Practice clerkship at the end of the sixth year.

Leiden:

The fourth-year students (pre-ALCO group) received the same invitation and the same financial compensation. To the ALCO-students the experiment was presented as an integral part of the final week of the ALCO programme (post-ALCO group). To the sixth year students it was presented as part of the one week training preceding the next clerkship. All of these students were expected to participate. The resulting numbers of students in each group are given in Table 1.

Table 1. Numbers of students in each group

\begin{tabular}{lcc}
\hline year & Maastricht & Leiden \\
\hline pre-ALCO & & 28 \\
$4 /$ post-ALCO & 38 & 33 \\
$6 / 6$ & 38 & 24 \\
\hline
\end{tabular}

\section{Multiple station examination}

The multiple station examination consisted of four 15 minute stations in which students did an entire consultation with a standardised patient. The standardised patient cases were evenly distributed across gender, age, setting (primary care or outpatient clinic with a referral, representative of Dutch health care situation) and communication skills required. Based on earlier data, a combination of four stations was considered to be sufficient to allow comparisons of mean scores at the group-level. ${ }^{27}$ For the four cases, the emphasis was on: clarification of the patient's exact reason for visiting the doctor, history taking and explanation, negotiation, and breaking bad news.

Medical content of the respective cases consisted of: iliotibial friction syndrome, hypothyroidism, pregnancy with high blood pressure and reduced foetal development, and adenocarcinoma of the prostate (see figure I). 
The experiments took place in the students' own school, i.e. for the Maastricht students the experiment was conducted in the Skillslab, where they had received their training and the Leiden students participated in the experiment in the ALCO skillstraining centre.

\begin{tabular}{|c|c|c|c|c|}
\hline gender & age & setting & diagnosis & communication skills \\
\hline $\operatorname{man}$ & 45 & GP & iliotibial friction syndrome & problem clarification \\
\hline woman & 58 & GP & hypothyroidism & history, explanation \\
\hline woman & 32 & Obstetrics & pregnancy with & negotiation \\
\hline man & 62 & $\begin{array}{l}\text { Internal } \\
\text { Medicine }\end{array}$ & $\begin{array}{l}\text { high blood pressure } \\
\text { reduced foetal development } \\
\text { adenocarcinoma } \\
\text { of the prostate }\end{array}$ & breaking bad news \\
\hline
\end{tabular}

Figure 1. Cases in the multiple station examination

For the multiple station examinations in both schools, standardised patients from Maastricht and from Leiden were used. Preparation of standardised patients involved a written, fixed scenario per case, and training by one experienced trainer. At the start of the multiple station examination all students received the following standardised instructions:

- the focus of this test is on the quality of communication with the patient

- the experiment will have no consequences for your study progress

- your name is recorded to enable standardised feedback at a later date

- you will rotate through the stations according to an individual schedule

- you have no more than 15 minutes for each patient encounter

- you will find standardised instructions concerning each case in the room

- after reading the instructions you can call in the standardised patient

- you must keep track of the time yourself

- you are expected to do a whole consultation, except for the physical examination. When you would perform physical examination if this were a real consultation, you can ask the observer for a handout which will show results, cliagnosis and advice

- you will receive no immediate feedback after each consultation; when you have completed all four stations you will receive copies of the ratings of your four stations. 


\section{Instrument}

The instrument used was the MAAS-Global. This instrument consists of a checklist and a 20-page scoring manual, listing criteria per item. In the checklist twelve caseindependent items were used, which were rated on a 6-point scale. The focus of this instrument is on the communication process, rather than the content, i.e. how questions are asked rather than what is asked. As much as possible the criteria have been operationalised as observable behaviour. The MAAS-Global has been validated in several studies. ${ }^{23,27-2,9}$

Since Maastricht students have been tested previously with the MAAS-Global, which might have given them an advantage, an overall general judgement of the quality of the communication in the whole consultation was also used. A general mark was given on a 10-point scale (1-10).

In both schools, raters from Maastricht and from Leiden observed the students during the consultations, blinded to the students' year groups. They completed the checklist and gave a mark immediately after each consultation. The raters received a standardised training, carried out by one experienced trainer. The Leiden preALCO students had not participated in a multiple station examination before this study. In order to identify whether a learning effect occurred in this group during the experiment, the order in which the students saw the four cases was recorded.

\section{Statistical analyses}

Cronbach"s alpha was calculated across the four cases in order to express the internal consistency of the multiple station examination. The results on the four cases were combined and converted to a percentage scale. After determining whether the distributions of the scores were normal, T-tests were used for the comparison of the means of two subgroups, and Anovas for the comparison of the means of three subgroups, assuming a critical p-value of 0.01. To establish which of the pairs of subgroups caused the difference. 'Tukey's Honestly Significant Difference post-hoc test whas used.

\section{RESULTS}

To check the representativeness of the participating student groups in Maastricht, their marks on the annual multiple station examination (skills test) were compared with those of the other students of their year group. At the $p<.01$ level, no difference was found between the participating and the non-participating groups. The skills-level of the participating students can therefore be considered representative of all students of their year groups. For Leiden these data were not available. How- 
ever, random sampling may be assumed for the post-ALCO and the sixth-year groups because of their participation according to a fixed regular schedule.

With the non-parametric K-S (normal) test the distributions of the MAAS-Global scores and the general mark were found to be normal. Cronbach's alpha across the four cases was 0.52 .

The Maastricht students were familiar with the procedure of a multiple station examination, whereas the Leiden pre-ALCO students were not. A systematic lower score of the Leiden pre-ALCO students for the first consultation might have been the result of this unfamiliarity. However, there was no significant difference between the mean scores obtained by the Leiden fourth-year students on the first. second, third and fourth cases. An increase in communication skills due to the multiple station examination did not occur.

More raters who were experienced in using the MAAS-Global were available in Maastricht than in Leiden. However, the mean results by raters from Maastricht and from Leiden did not differ. Apparently, the difference in experience between the raters has had no demonstrable effect on their judgements.

\section{Checklist}

The percentage scores on the MAAS-Global, per city, per curriculum year, over the four cases, are given in table 2.

Table 2. MAAS-Global scores (percentage scores of the four cases combined)

\begin{tabular}{lcccccccc}
\hline & \multicolumn{2}{c}{ Maastricht } & & \multicolumn{3}{c}{ Leiden } \\
\cline { 2 - 7 } year & mean & SD & $N$ & & mean & SD & $N$ \\
\hline pre-ALCO & 70.3 & 6.3 & 38 & & 56.1 & 7.1 & 28 \\
4/post-ALCO & 67.3 & 5.1 & 38 & & $58.0^{1}$ & 6.9 & 33 \\
$6 / 6$ & & & & $62.0^{1.2}$ & 5.8 & 24 \\
\hline
\end{tabular}

${ }^{1} p<0.01$ between Maastricht and Leiden (T-test)

${ }^{2} p<0.01$ between Leiden pre-ALCO and year 6 (Anova, Tukey"s HSD)

At all phases Maastricht students have higher scores than their colleagues from Leiden. The Leiden students" scores increase between pre-ALCO and sixth year, whereas their Maastricht colleagues show no significant change. A comparison of the fourth-year Maastricht and post-ALCO Leiden students revealed that Maastricht students scored significantly higher on every item of the MAAS-Global checklist, with the exception of 'History Taking' and 'Structuring', on which there was no significant difference. The items on which the Maastricht sixth-year stu- 
dents scored significantly higher than the Leiden sixth-year students were: "Opening": "Problem Clarification': 'Exploration' and 'Summarizing". On the other items there was no significant difference.

\section{General mark}

In addition to the MAAS-Global checklist score, students received a general mark (1-10) about the overall quality of the communication in each consultation. The combined results are shown in table 3.

Table 3. General mark (10-point scale of the four cases combined)

\begin{tabular}{llllllll}
\hline & \multicolumn{3}{c}{ Maastricht } & & \multicolumn{3}{c}{ Leiden } \\
\cline { 2 - 3 } year & mean SD & $N$ & & mean & SD & $N$ \\
\hline pre-ALCO & & & & & 5.9 & 0.6 & 28 \\
4/post-ALCO & 7.0 & 0.6 & 38 & & $6.2^{2}$ & 0.7 & 33 \\
$6 / 6$ & 6.8 & 0.5 & 38 & & $6.5^{3}$ & 0.6 & 24 \\
\hline
\end{tabular}

${ }^{1} p<0.01$ between Maastricht and Leiden (T-test)

${ }^{2} p<0.01$ between Leiden pre-ALCO and year 6 (Anova, Tukey's HSD)

Maastricht fourth-year students received higher general marks than Leiden pre- or post-ALCO students, In the sixth year there was no significant difference between students from Maastricht and those from Leiden. The Leiden students' scores increase beween pre-ALCO and the sixth year.

\section{DISCUSSION}

Measured with the MAS-Global, fourth-year and sixth-year Masstricht students had better communication skills than Leiden students. Assuming that the students are comparable on entering medical school, this difference is likely to be atributable to the curricula they have been exposed to. Interestingly, Maastricht students acticve their maximum score at the end of the fourth year, after having finished their preclinical communication skills training in the Skillslab programme, whereas the scores of the Leiden students gradually increase during years five and six. In Leiden, the clinical phase starts with a gradual introduction and, preceding two clerkships, structured communication skills training takes place in two university teaching weeks. It is therefore likely that the different results are due to this distinc- 
tion: training results in improved communication skills, no training leads to stabilisation of these skills.

From the results of the present study it may be concluded that the Maastricht students have an adequate training programme in the preclinical period, reaching the highest quality of communication of the student groups compared. Leiden students benefit from training during the university teaching weeks, although on the checklist they do not reach the level of their Maastricht colleagues.

In the fourth year the Maastricht students received higher general marks than the Leiden students. No significant difference was found in the general marks of the sixth-year students from Maastricht and from Leiden. Even though the (Pearson) correlation between the scores on the MAAS-Global and the general mark is 0.86 $(N=161, p<0.01)$ the checklist and the general mark show different results. There may be several explanations for this. Leiden sixth-year students may show a comparable general communicative ability but stay behind Maastricht students in the quality of specific skills. Alternatively, a ceiling effect is likely to have occurred for the Maastricht students. The marks that students reach in this study are comparable to the marks reported in other studies using the same instrument (Maastricht students: $50.3 \%$ at the beginning of the third year, $60 \%$ at the end of the third year) ${ }^{23}$ Moreover, these marks are high in comparison with those obtained by practising physicians $(44.4 \%-52.4 \%$ for general practitioners in a laboratory experiment and $42 \%$ in practice) ${ }^{29}$ On these occasions it has been noted that the criteria used in the MAAS-Global are quite demanding. However, the criteria are based upon theoretical notions and research findings, and satisfaction with the communication between practising doctors and their patients is also frequently reported as low. 8.9

No significant difference was found between the Maastricht students who participated in this experiment and their non-participating colleagues on their annual test of physical examination and communication skills. Although not significant, participating fourth year students had a higher mean score on the skills test than their non-participating colleagues. There may have been a somewhat positive selection in the sample of participating students in the Mastricht fourth year group. This was not the case in the Maastricht sixth year group. Because of the period when and the way in which the Leiden students were recruited, i.e. between March and June, 1999 , according to a standard schedule, these groups were likely to be representative of their year groups. However, this could not be substantiated because data were not available.

The Maastricht students were familiar with skills assessment and the instrument used, whereas the students from Leiden were not. However, in communication skills assessment, behaviour is evaluated, i.e. the students must demonstrate the required skills in consultations with patients. The teaching goals of the Leiden communication skills training programme are the same as those of the Mastricht 
programme. It is unclear whether mere acquaintance with the instrument would give the Maastricht students an advantage.

Comparability at entry of medical schools is likely. Secondary schools in The Netherlands have quite comparable quality. To allocate medical school places, medical students are subjected to a national procedure, basically a weighted lottery based on students' preferences for a university. Comparison of other examinations have never demonstrated any entry differences between Dutch medical schools. ${ }^{30}$

This study was not set up as a controlled trial, since there were no control groups available of students who had no training in cormmumication skills. Also, there may be many more influences on students" [communicative behaviour in the two curricula than those addressed in the study. These influences cannot be isolated. It is therefore assumed that these influences impact equally on students of both schools. In a problem-based learning (PBL) curriculum students frequently work together in small groups. They define learning goals and report to each other. This may have a positive influence on their general level of communication. 26 it is not likely that this influences the specific communication skills that are needed in the doctorpatient encounters studied. In a PBL curriculum more time is avalable for selfdirected learning, compared to a traditional curriculum. It could be argued that the Maastricht students have used more of that time practising doctor-patient communication than their Leiden colleagues. Two studies detail how Maastricht (PBL-) students spend the time for self-directed learning. 31,32 In a block of 6 weeks students spend an average of 84 hours in self study. Of these 84 hours they report to spend 2 hours each block preparing for their communication skills training programme. This is actually less than the time they would need to review all videolapes of the simulated patients encounters. It is therefore unlikely that the Maastricht students have spent more time practising doctor-patient communication compared to their Leiden colleagues.

The longitudinal integrated communication skills training programme, embedded in a problem based curriculum seems to be superior to the concentrated programme in a traditional curriculum and formal training during clerkships has a positive effect on the quality of the communication. These findings suggest that the preferred approach to communication skills training would be an integrated, longitudinal programme, which continues during the clinical years.

Further studies into the comparability of students enrolling in different curricula, and in the relative contribution of parts of curricula to communication skills are strongly recommended. 


\section{LITERATURE}

1. Sanson-Fisher R, Fairbaim S, Maguire P. Teaching skills in communication to medical students -a critical review of the methodology. Medical Education $1981 ; 15: 33-7$.

2. Caroll JG, Monroe J. Teaching clinical interviewing in the health professions. A review of empirical research. Evaluation in the Health Professions 1984;3:21-45.

3. Kraan HF, Crijnen A. The Maastricht history taking and advice checklist: studies of instrumental utility. [dissertation] Maastricht: University Press; 1987.

4. Hoppe RB, Farquhar LJ, Henry RC, Stoffelmayr BE, Helfer ME. A course component to teach interviewing skills in informing and motivating patients. Joumal of Medical Education 1988;63:176-80.

5. van Dalen J, Zuidweg $\mathbf{J}$, Collet $\mathbf{J}$. The curriculum of communication skills at Maastricht medical school. Medical Education 1989;23:55-61.

6. Roter DL, Hall JA. Doctors talking with patients: improving communication in medicine. London: Auburn House; 1992.

7. Ong LML, de Haes JCJM, Hoos AM, Lammes FB. Doctor patient communication: a review of the literature. Social Science and Medicine 1995;40:90318.

8. Kurtz S, Silverman J, Draper J. Teaching and learning communication skills in medicine. Oxon: Radcliffe Medical Press; 1998.

9. Silverman J, Kurtz S, Draper J. Skills for communicating with patients. Oxon: Radcliffe Medical Press; 1998.

10. Aspregren K. BEME guide no. 2: Teaching and learning communication skills in medicine -a review with quality grading of articles. Medical Teacher 1999;21:563-70.

11. Helfer RE. An objective comparison of the paediatric interviewing skills of freshman and senior students. Pediatrics 1970;45:623-7. 
12. Bishop IM, Fleetwood-Waker P, Wishart E, Swire H, Wright AD, Green ID. Competence of medical students in history taking duning the cinical course. Medical Education 1981;15:368-72.

13. Riccardi VM, Kurtz, SM. Communication and counselling in health care. Springfield, 111.: Charles C. Thomas; 1983.

14. Bowman FM, Goldberg DP, Millar T, Gask L, McGath G. Improving the skills of established General Practitioners: the long term benefits of group teaching. Medical Education 1992;26:63-8.

15. Maguire P, Fairbain S, Fletcher C. Benefits of feedback training in interwiewing as students persist. British Medical Journal 1986:292:1573-8.

16. Rutter DR, Maguire P. History taking for medical sudents II: evaluation of a training programme. Lancet 1976:226:556-60.

17. Flaherty IA Education and evaluation of interpersonal skills. In: Rezler AG, Flaherty, A, editors. The interpersonal dimension in medical education. New York: Springer Verlag; 1985:101-46.

18. GMC, Educational Committee. Tomortow's doctors. London: General Medical Council; 1993.

19. AAMC. Report II. Contemporary issues in medicine: communication in medicine. Medical schoots objectives project. Washington: Association of American Medical Colleges; 1999.

20. Wouda I, van de Wie. HBM. Communicatieve vaardigheden: een diagnose en een advies. [Commumication skills: a diagnosis and an advice] Bulletin Medisch Onderwijs 1992;11:116-8.

21. wan Dalen J, Bartholomeus P. Training clinical competence in a SkillsKaboratory. In: Bender W, Hiemstra RJ, Scherpbier AJJA, Zwierstra RP, editors. Teaching and assessing clinical competence. Groningen: Boek Werk Publications: 1990 .

22. van Dalen J, editou. Skillslab, centre for taining of skills. Maastricht: University Press; 2000 . 
23. van Dalen J, Prince CJAH, Scherpbier AJJA, van der Vleuten CPM. Evaluating communication skills. Advances in Health Sciences Education 1998;3:187-95.

24. van der Vleuten CPM, Scherpbier AJJA, Wijnen WHFW, Snellen HAM. Flexibility in learning: a case-report on problem based learning. International Higher Education 1996;2:17-24.

25. Studiegids Geneeskunde. Curriculum 1999-2000. Dienst onderwijs- en studentenzaken, Faculteit der Geneeskunde, Rijksuniversiteit Leiden. [Study guide Faculty of Medicine, University of Leiden]

26. Holm U, Aspregren $K$. Pedagogical methods and affect tolerance in medical students. Medical Education 1999;33:14-8.

27. van Thiel $\mathbf{J}$, van der Vleuten CPM, Kraan HF. Assessment of medical interviewing skills: generalisability of scores using successive MAAS-versions. In: Harden R, Hart I, Mulholland $H$, editors. Approaches to the assessment of clinical competence. Proceedings of the fifth Ottawa conference. Centre for medical education, University of Dundee: Scotland; 1992.

28. van Thiel J, Kraan HF, van der Vleuten CPM. Reliability and feasibility of measuring medical interviewing skills: the revised Maastricht history taking and advice checklist. Medical Education 1991;25:224-9.

29. Ram P, van der Vleuten CPM, Rethans J-J, Grol R, Aretz K. Assessment of practising family physicians: comparison of observation in a multiple station examination using standardised patients with observation of consultations in daily practice. Academic Medicine 1999;74:62-9.

30. Verhoeven BH, Verwijnen GM, Scherpbier AJJA, Holdrinet RSG, Oeseburg B, Bulte JA, van der Vleuten CPM. An analysis of progress lest results of PBL and non-PBL students. Medical Teacher 1998;20:310-6.

31. van der Hurk MM, Wolfhagen HAP, Dolmans DHJM, van der Vleuten CPM. Een inventarisatie van de studielast in het preklinische curriculum geneeskunde. [Detailing the time students spend in a pre-clinical medical curriculum] In: ten Cate ThJ, Dikkers JH, Houtkoop E, Pollemans MC, Pols J, Smal JA, editors. Gezond Onderwijs-5. [Proceedings of the 5th conference of the Dutch Society of Medical Education] Houten: Bohn Stafleu Van Loghum; 1996. 
32. Jongbloets MWM, Dolmans DHIM, Hoogenboom RJI, Wolfhagen HAP. Het ritme van de tijdbesteding van de $\mathrm{PGO}$-student [How do PBL-students divide their lime between regular coursework and self-directed learning]. Dutch Journal of Medical Education 2000;19:49-56. 


\section{CHAPTER 7}

\section{Development of communication skills in the medical curriculum ${ }^{1}$}

T he study investigates differences in communication skills of students during different skills training programmes at two medical schools.

The programmes are comparable in objectives, content and anount of tranng-time but one is a longitudinal, pre-clinical programme, the other consists of concentrated training periods in different curriculun-phases.

1414 Volunteer students from all classes at both schools took a knowledge about communication skills test, 78 items (true-false fonmal), $A$ conelation between knowledge-tests and skills-perfornance tests has earlier been found

Test scores increase with training $(p<0,05)$. The longtudinal, integrated raining programme shows a gradual increase in scores which peak at the end of the traning programme. The results stabilise when training ceases, during the clineal part of the curriculum. The concentrated programme initially shows a nore fitul pattem of scores, followed by growth in eommunication skils during he clinical years: At the end of the finat year students in both schools reach the same find SCOre:

The longifudinal, integated preclinical communication $\$ \mathrm{kils}$ training programme gives the best results when training is coninuing The gradual introduction to elincal medicine in one school leads to continued growh in communication proficiency during the clincal clerkship, absent in the other school optinal training of communication skills in a medical curriculum seems to be a longinudinal training programme covering the whole curriculum.

\section{INTRODUCTION}

In the past two decades, the teaching of communication skills has received considerable attention in medical schools. A wealth of research has been published about

\footnotetext{
'Submitted as: van Dalen J, van Knippenberg-van den Berg BW, Kerkhofs E, van den Hout HA. Verwijnen GM, Scherpbier AJJA, van der Vleuten CPM. Progress evaluation of communication skills: a paper-and-pencil test administered in two medical schools.
} 
the impact of poor doctor-patient communication, and how poor communication skills can be improved. 'It has been established that medical students' communication skills deteriorate in the absence of training. ${ }^{2.4}$ Different approaches to communication skills training have also been investigated. ${ }^{5-8}$ The studies addressed in these reviews were mostly concerned with concentrated courses. Aspregren in particular advocates that the training of communication skills be concentrated in the clinical phase of the medical curriculum. Insight from the field of cognitive psychology suggests that courses should provide frequent opportunities for practising the skills students have learned, in the context of the future working setting, which also lends support to training during the clinical phase." However, it has also repeatedly been suggested that, for training to have a lasting effect, it should be helical and longitudinal with maximum integration in the other parts of the curriculum. 16.16 In an attempt to find evidence of the effectiveness of either approach, we conducted a cross-sectional study, comparing the effectiveness of a longitudinal versus a concentrated communication skills training programme. In the study a paper-andpencil test of communication skills was applied to a medical school using a longitudinal programme and a medical school using a concentrated programme.

\section{Participating Schools}

The study was conducted in two Dutch medical schools. We selected the medical schools of Maastricht and Leiden, because the most recent survey of communication skills training at Dutch medical schools found that the most marked differences between training programmes were found between these two schools. ${ }^{17}$

The communication skills programmes of these schools are comparable in some ways. They have similar learning objectives and the programmes use similar teaching materials and training formats, such as role play, exercises and simulated parient encounters followed by feedback. The overall amount of time devoted to communication skills is not very different. The differences between the schools are found in the overall curricular approach and in the way communication skills training is scheduled in the curriculum. At Maastricht communication skills training is provided during the first four preclinical years as part of the systematic, integrated, longitudinal skills training programme of the Skillslab. ${ }^{18.19}$ This programme is characterised by a helical approach: students practise relevant communication skills in a continuous alternation of exercises, role-play and simulated patient encounters with feedback. ${ }^{26}$ Groups of ten students meet once every two weeks with one or two teachers. ${ }^{21} .22$ There is no systematic skills training during the final two clinical years of the curriculum. At Leiden, the communication skills training programme consists of three stages: two concentrated courses in the second and third year, a five-week full-time introduction to clinical medicine course in an introductory clerkship (ALCO programme) at the beginning of the clinical phase and two 
concentrated training courses preceding two clerkships. At both schools the clinical phase consists of clerkships during years 5 and 6 .

Further instructional differences can be summarised as follows: the Maastricht curricullum is problem based, with emphasis on small group sessions, ${ }^{23}$ whereas Leiden medical school is characterised by a more traditional, primarily lecture-based curriculum. ${ }^{24}$ Leiden students participate in a formal introductory course to the clinical clerkships whereas Maastricht students receive no such introduction. Claims have been made that problem-based learning promotes competence in general communication skills, although its effect on doctor-patient communication has not been studied systematically. ${ }^{25}$ This complicates the interpretation of any differences found in communication skills between the two medical schools, because these may be confounded by a problem-based learning effect.

\section{METHOD}

\section{Design}

Verhoeven et al. have demonstrated that student groups entering different medical schools in the Netherlands have similar results on formal tests. ${ }^{26}$ Comparability of the Maastricht and Leiden student groups at entrance is therefore assumed.

A longitudinal design is indicated to assess and compare the development of students' communication skills throughout the medical curriculum. However, crosssectional curves of progress tests results (a comprehensive test of general medical knowledge) have been shown to be more or less comparable to longitudinal ones, for the year groups of 125 students in Maastricht twenty years ago. ${ }^{29}$ Because year group size, in Maastricht as well as in Leiden, has increased to 200, it may be assumed that there are no systematic differences between different year groups. A cross-sectional design can therefore be considered to be predictive for a true longitudinal study.

\section{Subjects}

Students at the end of all six curriculum years in the medical schools of Maastrichi and Leiden volunteered to co-operate in the study. At Maastricht, also all students entering the medical school participated, cluring the second week of the first year ('year 0 ' group). All participating students received standardised feedback: their own score together with the mean score and standard deviation of their year group at their school. Students received a small financial compensation for their participation. Whether the participating Maastricht students were representative of the entire class was calculated by comparing their scores on the progress test of knowledge ${ }^{28}$ with those of the non-participating students. In years $2,3,5$ and 6 , the 
edge ${ }^{28}$ with those of the non-participating students. In years $2,3,5$ and 6 , the groups had similar scores. In year 1, the participating group scored lower than the non-participating group ( $\mathrm{T}$-test; $\mathrm{F}=9.84, \mathrm{df}=205 ; p<0.01$ ). In year 4 , the participating students had a higher score than their non-participating colleagues ( $T$-test; $\mathrm{F}=1.09$, $\mathrm{df}=198 ; p<0.01)$. In Leiden, achievement data were unavailable, so a similar comparison could not be made.

\section{Instrument}

Assessment of communication skills usually relies on some form of multiple station examination. ${ }^{29-37}$ Because of case specificity, repeated measurements are needed. ${ }^{38.39}$ A true continuous assessment of communication skills is therefore costly.

Various studies have reported a high correlation between assessment of skills performance and knowledge tests of skills. ${ }^{40-43}$ Although a test of knowledge of skills cannot be used as a substitute for a performance test, it can be used to assess the development of communication skills of groups of medical students as they progress through the medical curriculum.

The instrument used in this study is a 78-item paper-and-pencil test of knowledge about communication skills, using true-false questions. As much as possible, the items measure applied knowledge, i.e. which intervention is preferred over altematives in a certain situation. The instrument has been developed by selecting the relevant items from a pool of about 18,000 items for the assessment of knowledge in the medical school at Maastricht. The procedure used in item production has been documented by Verhoeven et al. ${ }^{26}$ All items have the format of a stem or a vignette with a statement. The statement is either true or false. The students choose between true and false, and if they do not know the answer, they can choose the "I don't know" option, a question mark. A student's score is expressed as percentage correct-minus-incorrect answers. An example of two items of this instrument can be found in figure 1 .

Construct validity of the knowledge of skills test has been demonstrated by a significant correlation between this test and a performance test of communication skills. Discriminant validity was indicated by a correlation of close to zero with results on the progress test and on the test of a wide range of procedural clinical skills, the annual OSCE. ${ }^{44}$ 
To help a frightened patient expand on his complaints, certain communication skills are more adequate than others. Assuming that all interventions are spoken in an understanding tone of voice, in the majority of cases:

"In reality it is often not so bad..." is better than:

"It frightens you, doesn't it?"

true $/ ? /$ false

"What is it that frightens you?" is better than:

"I have experienced something similar..."

tue / ? Ialse

Figure 1. Example of a stem and two items of the knowledge of communication skills questionnaire

\section{Statistical analysis}

The correct minus incorrect scores were converted to a percentage of the maximum score. To report the teliability of the knowledge of communication skills test Cronbach"s alpha was calculated. With the K-S (nomal) test the distribution of the scores was assessed. Following that, T-tests were used to calculate differences between the same year groups in the two medical schools.

\section{RESULTS}

Cronbach's alpha of the knowledge of communication skills test is 0.76 for the whole group, 0.78 in Maastricht and 0.71 in Leiden. The percentage scores of the different year groups in the medical schools of Mastricht and Leiden are presented in Table 1.

In the curriculum years 1 through 4 , the Maastricht students have higher scones than their Leiden colleagues. In the years 5 and 6 there is no difference between the scores of students in the two schools. The increase in scores from year 1 to 4 is gradual in Maastricht. There is no significant change after that. In Leiden, there is an abrupt increase in year 3 , no significant change in year 4 , a rise in year 5 and stabilisation in year 6 . 
Table 1. Percentage score (correct minus incorrect) on the knowledge of communication skills test, by class and by medical school.

\begin{tabular}{|c|c|c|c|c|c|c|}
\hline & $\mathrm{Ma}$ & astrich & & & iden & \\
\hline & Mean & $\mathrm{SD}$ & $\mathbb{N}$ & mean & $\overline{S D}$ & $\mathbb{N}$ \\
\hline 0 & 28.0 & 13.0 & 199 & - & - & - \\
\hline 1 & 47.3 & 12.8 & 145 & $32.8^{i}$ & 13.3 & 117 \\
\hline 2 & 50.7 & 13.5 & 137 & $37.8^{1}$ & 14.1 & 93 \\
\hline 3 & 58.0 & 12.2 & 123 & $51.8^{1}$ & 13.7 & 62 \\
\hline 4 & 59.8 & 11.9 & 137 & $46.9^{\prime}$ & 13.6 & 145 \\
\hline 5 & 56.7 & 12.4 & 96 & 56.1 & 10.9 & 55 \\
\hline 6 & 55.6 & 11.0 & 65 & 55.6 & 10.2 & 40 \\
\hline
\end{tabular}

'Difference between Maastricht and Leiden, $p<.01$

Differences between schools in scores of the same year groups are shown in figure 2.

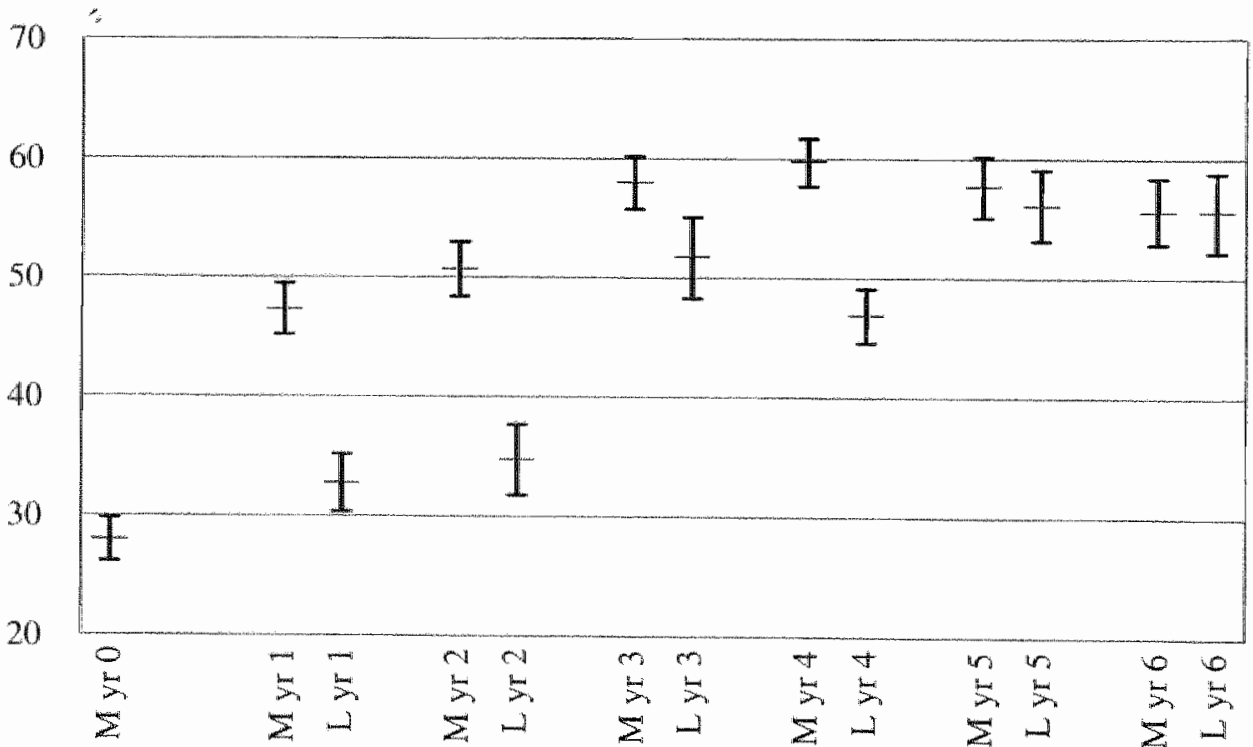

Figure 2. Means and $95 \%$ confidence intervals of the knowledge of communication skills test correct minus incorrect scores, per class per medical school. A difference is significant at the $p<0.05$ level if the confidence intervals do not overlap. $M=$ Maastricht, $\mathrm{L}=$ Leiden. 


\section{DISCUSSION}

Bearing in mind that this is a cross-sectional study, the following conclusions can be drawn. The results on the knowledge about communication skills test closely reflect the training programmes. By and large it can be said that scores increase when training is provided and stabilise when there is no training. Maastricht students show the largest improvement during year 1, and their score increases steadily during years $1-4$. This reflects the four year communication skills training programme at the Skillslab. After year 4 systematic training stops, and test scores stabilise. In Leiden the students receive communication skills training in years 2 and 3. A sharp rise in the scores is found in year 3. In year 4 there is no training and the scores remain similar. The five-week full-time introduction to clinical medicine course (ALCO) and a training in year 5 is reflected in another sharp rise in the scores. The level reached at the end of year 5 in Leiden is maintained until the end of the final year, despite additional communication skills training in this year. There are several possible explanations for this finding. The communication skills addressed in this training, which precedes a clerkship, may be too specialised to be reflected in an increased score on the test, or the test may not be sensitive enough to detect changes in communication skills, brought about by this training. A training effect may also be that the scores do not decline, as has been shown to happen in the absence of training. However, Aspregren's guidelines suggest that better results than those found in our study are to be expected from systematic training during the clinical phase. ${ }^{8}$ The findings in our studly appear to suggest a modification of Aspregren's suggestion from 'communication skills training ought to be concentrated in the clinical years' 8 to 'training is effective when students meet with patients, either in a laboratory or a clinical setting. regardless of the phase of the curriculum. This can be in the healch care situation, as in the clinical phase of the curriculum, and earlier, with the help of simulated patients.

The final scores of students in both curricula are exactly the same. At first sight, the way training is scheduled in the curriculum makes no difference. There are however differences in the developmental patterns of communication skills in the two schools that might point to ways of improving communication skills training. By combining the best of the two approaches, Maastricht would benefit from a continuation of training in the clinical phase and Leiden's achievements might be enhanced by an earlier start, preferably integrated in the curriculum. It would be interesting to monitor such a programme to establish whether students can learn to communicate better still. 


\section{LITERATURE}

1. Silverman J, Kurtz S, Draper J. Skills for communicating with patients. Oxon: Radcliffe Medical Press; 1998.

2. Helfer RE. An objective comparison of the pediatric interviewing skills of freshmen and senior students. Pediatrics 1970;45:623-7.

3. Bishop IM, Fleetwood-Walker P. Wishart E, Swire H, Wright AD, Green ID. Competence of medical students in history taking during the clinical course. Medical Education 1981;15:368-72.

4. Pfeiffer C, Madray H, Ardolino A, Willms J. The rise and fall of students' skill in obtaining a medical history. Medical Education 1998;32:283-8.

5. Caroll JG, Monroe J. Teaching clinical interviewing in the health professions. A review of empirical research. Evaluation in the Health Professions 1984;3:21-45.

6. Ong LML, de Haes JCJM, Hoos AM, Lammes FB. Doctor patient communication: a review of the literature. Social Science and Medicine 1995;40:903-18.

7. Kurtz S, Silverman J, Draper J. Teaching and learning communication skills in medicine. Oxon: Radeliffe Medical Press; 1998.

8. Aspregren K. BEME guide no. 2: Teaching and learning communication skills in medicine - a review with quality grading of articles. Medical Teacher 1999:21:563-70.

9. Norman G. Regehr G. Issues in cognitive psychology: implications for professional education. Academic Medicine 1996;71:988-1001.

10. Rutter DR, Maguire P. History taking for medical students II: evaluation of a training programme. Lancet 1976;226:556-60.

11. Riccardi VM, Kurtz SM. Communication and counselling in health care. Springfield, Ill.: Charles C. Thomas; 1983.

12. Flaherty JA. Education and evaluation of interpersonal skills. In: Rezler AG, Flaherty A, editors. The interpersonal dimension in medical education. New York: Springer Verlag; 1985. 
13. Maguire $P$, Fairbairn $S$, Fletcher $C$. Benefits of feedback training in interviewing as students persist. British Medical Joumal 1986;292:1573-8.

14. Bowman FM, Goldberg DP, Millar T, Gask L, McGrath G. Improving the skills of established General Practitioners: the long term benefits of group tenching. Medical Education 1992;26:63-8.

15. GMC, Educational Committee. Tomorrow's doctors. London: General Medical Council; 1993.

16. AAMC. Report III. Contemporary issues in medicine: communication in medicine. Medical schools objectives project. Washington: Association of American Medical Colleges; 1999.

17. Wouda J, van de Wiel HBM. Communicatieve vaardigheden: een diagnose en een advies. [Communication skills: a diagnosis and an advice] Bulletin Medisch Onderwijs 1992;11:116-8.

18. van Dalen J, Bartholomeus $\mathbb{P}$. Training clinical competence in a Skillslaboratory. In: Bender W, Hiemstra RJ, Scherpbier AJJA, Zwierstra RP, editors. Teaching and assessing clinical competence. Groningen: BoekWerk Publications; 1990.

19. van Dalen J, editor. Skillslab, centre for training of skills. Maastricht: University Press; 2000.

20. van Dalen J, Bartholomeus $P$, Kerkhofs E, Lulofs R, van Thiel $J$, Rethans $\mathbb{J}-J$, Scherpbier AJJA, van der Vleuten CPM. Teaching and assessing communication skills in Maastricht: the first twenty years. Medical Teacher 2001;23:24.5-51.

21. van Dalen J, Zuidweg J, Collet J. The cuiriculum of communication skills at Maastricht medical school. Medical Education 1989;23:55-61.

22. van Dalen J, Prince CJAH, Scherpbier AJJA, van der Vleuten CPM. Evaluating communication skills. Advances in Health Sciences Education 1998;3:187-95.

23. van der Vleuten CPM, Scherpbier AJJA, Wijnen WHFW, Snellen HAM. Flexibility in learning: a case-report on problem based learning. International Higher Education 1996;2:17-24. 
24. Studiegids Geneeskunde. Curriculum 1998-1999. Dienst onderwijs- en studentenzaken, Faculteit der Geneeskunde, Rijksuniversiteit Leiden. [Study guide Faculty of Medicine, University of Leiden]

25. Holm U, Aspregren K. Pedagogical methods and affect tolerance in medical students. Medical Education 1999;33:14-8.

26. Verhoeven BH, Verwijnen GM, Scherpbier AJJA, Holdrinet RSG, Oeseburg B, Bulte JA, van der Vleuten CPM. An analysis of progress test results of PBL and non-PBL students. Medical Teacher 1998;20:310-6.

27. Verwijnen GM, Imbos Tj, Snellen H, Stalenhoef B, Pollemans M, van Luijk S, Sprooten M, van Leeuwen Y, van der Vleuten CPM. The evaluation system of the medical school of Maastricht. Assessment and Evaluation in Higher Education 1982;3:225-44.

28. van der Vleuten CPM, Verwijnen GM, Wijnen WHFW. Fifteen years of experience with progress testing in a problem-based curriculum. Medical Teacher 1996:28:103-9.

29. Kraan HF, Crijnen A. The Maastricht history-taking and advice checklist: studies of instrumental utiliny. [Dissertation] Maastricht: University Press;1987.

30. Stillman PL, Swanson DB. Ensuring the clinical competence of medical school. graduates through standardised patients. Archives of Internal Medicine 1987;147:1049-52.

31. Roter DL Hall JA. Doctors talking with patients, patients talking with doctors. Westport, CT: Auburn House; 1992.

32. Bensing J. Doctor-patient communication and the quality of care [Dissertation] Utrecht: NIVEL; 1991.

33. Bögels SM, Teaching and assessing diagnostic interviewing skills, an application to the mental health field. [Dissertation] Maastricht: University Press; 1994

34. van Thiel J. Kraan HF, van der Vleuten CPM. Reliability and feasibility of measuring medical interviewing skills: the revised Maastricht history-taking an advice checklist. Medical Education 1991;2:224-9. 
35. van Thiel J, van der Vleuten CPM, Kraan HF. Assessment of medical interviewing skills: generalisability of scores using successive MAAS-versions. In: Harden R, Hart I, Mulholland H, editors. Approaches to the assessment of clinical competence. Proceedings of the fifth Ottawa Conference. Dundee, Centre for medical education, University of Dundee: Scotland; 1992.

36. Kurtz SM, Silverman JD. The Calgary-Cambridge observation guides: an aid to defining the curriculum and organising the teaching in communication skills programmes. Medical Education 1996; 30:83-9.

37. Ram P, van der Vleuten CPM, Rethans J-J, Grol R, Aretz K. Assessment of practising family physicians: comparison of observation in a multiple station examination using standardised patients with observation of consultations in daily practice. Academic Medicine 1999;74: 62-9.

38. van der Vleuten CPM, Swanson D. Assessment of clinical skills with simulated patients: state of the art. Teaching and Learning in Medicine 1990;2:58-67.

39. Newble DI, Swanson DB. Psychometric characteristics of the objective structured clinical examination. Medical Education 1988;23:325-34.

40. van der Vleuten CPM, van Luijk SJ, Beckers HJM. A written test as an alternative to performance testing. Medical Education 1989;23:97-107.

41. Janssen JJM, Tan LCH, van der Vleuten CPM, van Luijk S.J, Rethans J-I, Grol RPTM. Assessment of competence in technical clinical skills of general practitioners. Medical Education 1995;29:247-53.

42. Scherpbier AJJA. Kwaliteit van vaardigheidsonderwijs gemeten. [Measuring quality of skills training] [Dissertation] Maastricht: University Press; 1997.

43. Remmen R, Scherpbier AJIA, Derese A, Denekens J, Hermann I, Hoogenboom $R$, van der Vleuten $C$, van Royen P, Bossaert $L$. Correlations of written test of skills and a performance based test: validation study in two traditional schools. Medical Teacher 2001;23:29-32.

44. van Dalen J, Kerkhofs E, Verwijnen GM, van Knippenberg-van den Berg BW, van den Hout HA, Scherpbier AJJA, van der Vleuten CPM. Predicting communication skills with a paper-and-pencil test. Medical Education: in press. 


\section{Conclusion and discussion}

The core question addressed in this dissertation is: which factors in the medical

1 curriculum influence the effectiveness of communication skills training. We tried to answer this question by identifying how communication skills of medical students develop during the undergraduate curriculum. The specific research questions are:

1. How is the communication skills training programme organised? What has been described, and how is it intended? How does this curriculum 'on paper' relate to the relevant literature? (Structure)

2. What parts of the curriculum do students perceive as making the most influential contribution to their communication skills? (Process)

3. What are the psychometric characteristics of three different instruments for the assessment of communication skills (i.e. a checklist of performance, a concise global rating scale for performance and a test of knowledge about skills)? The answer to this methodological question was used to address the next research question:

4. How do the communication skills of medical students develop in a longitudinal versus a concentrated training programme? (Outcome)

The findings from the studies described in this dissertation are discussed below. The methodological limitations of the studies are discussed and the chapter concludes with an overall discussion of the findings and implications of the studies.

\section{Conclusions}

Regarding question 1 it has been found that the Maastricht communication skills training curriculum on paper fits the criteria of the desired training programme.

Nevertheless, some problems still remain unresolved:

- Instruction videotapes are recommended as a model of desired behaviour. We have found that it is very difficult to produce credible models. It requires substantial resources to record them and they are quickly outdated. As a result, the use of instruction videotapes has been abandoned.

- Although students expressed the desire to practise with entire consultations from the beginning of the course, this seems to be too complicated for first- 
year students. In the first year it is very difficult to find lopics that are easily translatable into realistic doctor-patient consultations.

The choice of behaviour as the focus of training appears to result in an underexposure of aspects of communication related to the personal awareness of attitude.

- The model that is used may not be generic, as is claimed. It is often stated that the model is too time-consuming, especially in the hospital setting. Possibly the model is not equally applicable across different situations, like the hospital setting, acute care, and consultations involving small children or third parties.

- The longitudinal programme structure, with student groups meeting every two weeks, may be too watered down. It is sometimes difficult to bridge the gap between two meetings. Students" learning goals are the guiding principle throughout the programme. It requires a considerable training investment to help students develop the motivation to adhere to this approach.

- The limitations of simulated patients are increasingly being felt by students in later years, as evidenced by the diminished interest in this form of teaching at the end of the preclinical phase. By that time students are getting tired of simulations, and long for "real life".

Concerning question 2 , i.e. the most influential contributions, it has been found that students perceive the actual training activities as making the best contribution to the development of their communication skills. These activities were judged as being more influential than the teacher-independent simulated patient encounters, the group sessions in which they reflect and elaborate on these encounters, the sessions on attinde awareness, or even the teachers didactic skills.

Concerning research question 3, the psychometric characteristics of different instruments for assessing communication skills: the most efficient instrument for judging the training programme would be the paper-and-pencil test of knowledge about communication skills. This instrument proved to be the most suitable one for providing information about groups of students. It would be a cheap alternative to an Objective Structured Clinical Examination (OSCE) for providing course organisers with information about the results of the programme. The concise global rat ing scale that was studied, the Respectful Conduct Scale (RCS), is intended as a tool for the integrated assessment of communication skills that requires only little additional time investment from examiners. Its reproducibility is better than that of the whole OSCE and of the MAAS-Global, a more detailed checklist of performance. However, it was found that the RCS better reflects the performance of the clinical procedural skill that is measured in the station than the communicative behaviour as measured by the MAS-Global. This means that it is not sufficiently 
valid to provide an independent consistent assessment of communication skills. A combination of both instruments would therefore be advisable.

The MAAS-Global is intended for the measurement of communication skills and for providing detailed feedback. The reproducibility found in this study is much lower than reported in earlier studies.' We found that the MAAS-Global requires a testing time of 13.5 hours to achieve an acceptable reproducibility. This may have been an effect of the sample used in the study. However, this poor reliability precludes conclusions about its validity for the assessment at individual level. More research into conditions that would improve reliability is clearly needed.

With respect to question 4 , the development of skills, we found that students in a longitudinal communication skills programme, which is integrated in the curriculum, achieve higher scores on an OSCE compared with students in a more concentrated training programme as measured with the MAAS-Global, a detailed communication skills checklist. Although the instrument is not sufficiently reproducible at individual level, these conclusions can reliably be drawn at group level. The longitudinal programme is limited to the preclinical phase of the undergraduate medical curriculum. During the clinical phase, where formal communication skills training is absent, the scores stabilise. The more concentrated training programme consisting of two courses in the preclinical years, followed by a gradual introduction in the clinical clerkships, and training in the clinical phase, leads to an increase in scores during the clinical phase. However, the scores never reach the same level as those achieved in the longitudinal programme. These findings are based on a crosssectional comparison of the scores on a detailed checklist, focusing on correct performance of specific communication skills. When a general impression is used to assess communication skills, this difference is no longer present.

At the end of the preclinical curriculum, a substantial correlation is found between the Maastricht students' knowledge about communication skills and skill performance. In Leiden this correlation is not significant. This may be attributable to differences in educational format. An integrated approach to teaching, as in the PBLcurriculum with a Skillslab in Maastricht, might result in a better integration of knowledge and performance.

A test of knowledge about communication skills that was administered in a cross sectional comparison of students of all year groups in Maastricht and Leiden revealed that training efforts are largely reflected in a rise in scores on the test. The final year students at both universities reach exactly the same end-score, but do so in very different ways. The students of the longitudinal preclinical programme show a steady rise of scores in the preclinical curriculum, with a stabilisation in the clinical phase. The pattern of scores of the students of the concentrated programme shows a rise over the years when training takes place. A more gradual introduction 
in the clinical phase, together with continued training, is reflected in an increase in the scores on the knowledge test of communication skills during the clinical phase. The overall conclusion of these studies is that the communication skills training programme in Maastricht shows many of the characteristics of adequate training programmes, although improvement seems possible by continuation of the training programme in the clinical phase and by earlier and more frequent student-patient. encounters. Below we will first address some methodological considerations of the studies. This chapter will end with more detailed conclusions and implications of these studies.

\section{METHODOLOGICAL CONSIDERATIONS}

The final three studies reported in this thesis were performed in two ongoing curricula, in which students participated in their regular educational sessions. It was therefore not possible to create controls for each of the study groups. A crosssectional design was used to compare the student populations from two different medical schools. These conditions set inevitable limitations to the generalisability of the results. Provided that the groups are large enough, a cross-sectional comparison resembles a true longitudinal study (compare data on progress testing, ${ }^{2}$ ). In the study using the paper-and-pencil test of knowledge about communication skills, the size of the samples of students who participated was substantial, on average half of the entire year groups. Where data were available, missing group analyses were performed. These revealed no significant differences between the groups of students who did and who did not participate. However, in Leiden these data were not available. Moreover, the groups that participated in the OSCE were considerably smaller. Again, missing group analyses revealed no differences between participating and non-participating students, but: in Leiden these data were not available.

The Maastricht medical curriculum is problem based, whereas that of the medical school in Leiden was primarily lecture based at the time of the studies. The impact of a problem based curriculum on the quality of the doctor-patient communication was not studied, but this may have co-varied with the independent variable, the different communication skills training programmes.

Another limitation is that the Maastricht students were more familiar with one of the instruments used, namely the MAAS-Global. This instrument is included in the training material that students use in the Maastricht medical school. The research team had agreed upon the use of this instrument, because it was judged to be the best available representation of the criteria of communication skills, but this might have created an advantage for the Maastricht students. For this reason a global rating of communication skills was added to the MAAS-Global. The difference be- 
tween findings obtained with these different instruments suggests the presence of an advantage to the Maastricht students.

\section{DisCussion AND IMPLICATIONS}

The importance of communication skills in medical education is firmly embedded in evidence. The effects of poor communication have been widely studied, as well as the beneficial effects when communication skills improve. Regarding the teaching, testing, and learning of communication skills, a number of final observations can be made.

\section{Teaching}

In the absence of teaching, medical students" communication skills deteriorate during a medical curriculum. From that point of view, it is remarkable that we found clear improvement of students' communication skills in both medical schools. Mere prevention of deterioration by itself would have been a positive effect.

As a result of the studies reported in this dissertation, we can make a more informed judgement on the benefits and limitations of a communication skills training programme. The helical approach is partly realised in the Maastricht preclinical programme: students practise in exercises and role play, as well as with simulated patients. Communication skills are represented in the annual OSCE. However, during the first four years students hardly practise communicating with real patients. In their excursions to health care practices during the preclinical period, their active experience with doctor-patient communication is variable, and the way in which attention is paid to communication skills is by no means structured for all students. ${ }^{3.4}$ In the Maastricht clerkships students see patients on a regular basis, but systematic communication skills training is absent and these skills do not improve. In the Leiden programme, communication skills training also takes place during the clinical phase in two university teaching weeks preceding two clerkships. This leads to further improvement in students' communication skills during the clerkships.

The patterns of the development of communication skills differ between Maastricht and Leiden, with Maastricht students showing a more gradual rise in communication proficiency. A more gradual increase in skill performance may lead to better retention of these skills, which would argue in favour of a longitudinal programme that continues throughout the clerkships. Further study into the long-term effects of communication skills training programmes is recommended.

It could be argued that the Maastricht skills training programme is costly. It is impossible to compare the specific cost of the communication skills training programmes in Maastricht and Leiden. A large proportion of both programmes is inte- 
grated with the (simulated patient based) teaching of clinical competence. Comparison of the cost of a problem-based curriculum to that of a lecture-based curriculum shows that in view of efficiency and other outcomes the problem-based curriculum is a cost-effective and attractive educational model. Appreciation of the PBL-curriculum is higher and more students graduate faster in Maastricht. ${ }^{5}$

\section{Testing}

Regarding the instruments for the assessment of communication skills: all instruments for monitoring student or curriculum development that were studied have benefits as well as disadvantages. Questionnaires asking students' opinions about the programme were a valuable source of information about what actually happens in the trainingsessions. Students gave adequate judgements about all aspects of the programme they participated in. They considered 'opportunity to practise' as the most important contribution to the learning effect of the programme, more important than teachers' didactic skills. Students' evaluation of teachers may have another advantage. Just like students' performance is strongly influenced by what is assessed, a similar effect is likely to occur in teachers: knowing that their teaching is systematically monitored may increase their motivation to do a good job.

Regarding the comparison between a detailed checklist of performance, a concise global rating scale of performance and a paper-and-pencil test of knowledge about communication skills, the latter appears to be the most efficient and objective way to monitor student development throughout the curriculum. The test is relatively simple to administer, sufficiently reliable and it has a promising predictive validity to give a judgement of the progress of student groups. The value of this test is less when used for formative or summative assessment of individual communication skills. When used to this end, the educational message would be that students should focus on the acquisition of knowledge. This would underemphasise the need to practise the application of communication skills. Furthermore, the approach practised in skills training is to confront the students with a situation to which they must individually respond, displaying their communication skills. Their own analysis, as well as feedback from fellow students and teachers should result in an increased intrinsic motivation to address theory. Even though this is not always recognisable in current teaching practice this order of events is likely to result in a higher retention of theoretical knowledge, compared to study assignments of which the relevance has not yet been experienced.

Theoretically, the detailed checklists and global rating scales for the assessment of performance, like the MAAS-Global and the RCS, have complementary benefits. The advantage of an elaborate checklist is that students receive detailed feedback. In the early years students learn to focus on the correct performance of basic communication skills in the context of a doctor-patient encounter. Especially in these years, detailed feedback is needed to shape their ability to self-analyse communica- 
tion skills. This ability is a skill health care professionals have to acquire for future practice when they are unlikely to be observed. However, a detailed communication skills checklist is costly to administer, since a separate observer is needed. Moreover, from the point of view of learning in context, separate assessment of communication skills, isolated from content, is less desirable.

A concise global rating scale administered in every station of an OSCE, does justice to the importance of communication skills in every doctor patient encounter. Repeated measures per student yield a reproducible score. The scale we have developed seems to be susceptible to a halo-effect. Its scores also reflect the scores of the clinical procedural skill tested in the station it was added to.

In the course of a curriculum, the preferred procedure would be to administer the detailed checklist in the early years, so that students can benefit from detailed feedback. In the later years this instrument can gradually be replaced by a valid concise global rating scale.

\section{Learning}

This study was not set up, or conducted, as a contest to decide which of the two schools is the winner. The studies were conducted in on-going curricula with intrinsic differences. The findings of these studies will certainly have been influenced by co-varying differences between these curricula. However, at what point do those differences become part of the curriculum rather than a contaminant? In the words of the Educational Psychologist Geoff Norman, Editor in Chief of Advances in Health Sciences Education: "It is a given that if we worked diligently to control all curriculum difference, we would eventually control away all curriculum effects". In the view of the researcher, the main result of these studies is that the development of communication skills in medical students, as influenced by their curricula, has been mapped somewhat better, and that potentially beneficial as:pects of both curricula have been identified. A well-structured communication skills training programme is likely to be successful when it is organised longitudinally, spanning the whole curriculum, maximally embedded in the other parts of the curriculum, with a helical structure with students alternating between practising amongst each other, via practising with simulated patients, to practising with real patients, on each occasion provided with feedback. A logical consequence is that student-patient encounters must be integrated in this ideal curriculum from the very beginning. A gradual introduction to the clinical phase of the curriculum is a necessary characteristic of this approach, because it will foster continued growth of communication skills throughout the curriculum. It should be noticed that the training activities in the clinical phase in Leiden took place in university teaching weeks between clerkships. That is not what we envisage as optimal, however beneficial these courses may be. Communication skills training in the final phase of the curriculum will benefit most from analysis and elaboration of encounters between stu- 
dents and real patients. The way that this should be organised is to provide students with multiple opportunities to video-record their communication with patients and to review these tapes. From our studies it can be concluded that the advantage of having a teacher present in these sessions is only relative in comparison with the opportunity to systematically analyse and compare individual approaches and to practise with alternatives. When resources are limited, it would be advisable to first concentrate on providing the opportunities for reflection on students" communication, and on creating a receptive climate for this in the educational context of clerkships. Only when these conditions have been met, should investment go to professionalising the teachers. We have found no systematic effect of the teachers' discipline on the learning effect that students report. It can be argued that psychologists, because of their training, are best suited for communication skills training. However, medical students have a strong tendency to identify with their teachers. To make use of that effect, doctors would be the preferred group of teachers. It is therefore likely that a pair of teachers, a doctor and a psychologist, would work best. This would bring the additional benefit of modelling interdisciplinary collaboration to the students.

The current model of desired communication skills has been developed in the 1970's. Society has changed considerably since then: an ageing population, tilling the care/cure balance, increased access to information through the media, patients with more specific demands of their doctor, as well as a culturally more diverse society will undoubtedly have changed the communication skills the present doctor needs. It is unlikely that a medical curriculum will ever be able to specifically prepare students for every situation they will face in the future. It must be an early course objective that students develop their ability to self-analyse. This is a skill that is likely to become as important as adequate communication skills themselves. Flexibility in communication and self-assessment may therefore represent training areas that are strongly indicated in the current medical curriculum. The instruments that have been studied can assist in acquiring these metacognitive skills.

The fact that students judged the teachers' contribution to their learning effect of lesser importance than their own opportunities to practise may indicate a future for more teacher-independent training aspects. However, students need observation for feedback and analysis of their communicative ability. A high-quality communication skills training programme will therefore never be cheap. Judging from the results that good doctor-patient communication can bring about, this is likely to be a small price to pay for a potentially large improvement. 


\section{LITERATURE}

1. van Thiel J, van der Vleuten CPM, Kraan HF. Assessment of medical interviewing skills: generalisability of scores using successive MAAS-versions. In: Harden R, Hart I, Mulholland H, editors. Approaches to the assessment of clinical competence. Proceedings of the fifth Ottawa conference. Centre for medical education, University of Dundee: Scotland; 1992.

2. van der Vleuten CPM, Verwijnen GM, Wijnen WHFW. Fifteen years of experience with progress testing in a problem-based curriculum. Medical Teacher 1996;28:103-9.

3. Crebolder HFJM, Metsemakers JFM. General practice, medical education and community-based teaching: the Maastricht experience. Annals of CommunityOriented Education 1994;7:121-9.

4. van Bokhoven MA, van Dalen J, Metsemakers JFM, van Enckevort C. The Maastricht adoption programme in general practice: the students' view. Education for Health 1998;11:57-64.

5. Nieuwenhuijzen Kruseman AC, Kolle LFJThM, Scherpbier AJJA. Problembased learning in Maastricht -an assessment of cost and outcome. Education for Health 1997;10:179-87.

6. Norman G. Personal communication, 2001. 
2 


\section{Summary}

$\mathrm{T}$ his dissertation focuses on the core question: which factors in the medical curriculum infuence the effectiveness of communication skills training? We tried to answer this question by identifying how communication skills of medical students develop during the undergraduate curriculum. The specific research questions are:

1. How is the communication skills training programme organised? What has been described, how is it intended? How does this curriculum "on paper' relate to the relevant literature? (Structure)

2. What parts of the curriculum do students perceive as making the most influential contribution to their communication skills? (Process)

3. What are the psychometric characteristics of three different instruments for the assessment of communication skills (i.e. a checklist of performance, a concise global rating scale for performance and a test of knowledge about skills)?

4. How do the communication skills of medical students develop in a longitudinal versus a concentrated training programme? (Outcome)

The results are summarised below, per chapter.

\section{Chapter 1: Teaching and assessing communication skills in Maastricht}

This chapter provides a context for the study to the readers who are not familiar with this programme.

Relevant literature about the influence of good and poor doctor-patient communication is reviewed. The stages in development of the communication skills training programme in the undergraduate curriculum in the Skillslab at the medical school of the University of Maastricht, The Netherlands, are described. A multidisciplinary working group developed teaching gaals for communication skills, focused on observable behaviour to be displayed by students. These teaching goals were incorporated in a generic model for doctor-patient communication. A longitudinal training programme was created, throughout the four years of the preclinical curriculum. In the development of this programme the following consecutive actions 
were taken: teaching material was produced, an assessment tool was developed, as were instruments for programme evaluation. The programme evaluation allowed student feedback to teachers, the teachers" departments, and the administration of the medical school. Finally, teacher training was professionalised.

The programme described is extensive and organisationally firmly embedded in the infrastructure of the Skillslab. However, many problens remain unsolved. Reviewed are the following: -entire consultations for first year students may be too complicated, -behaviour as topic of training underemphasizes attitude awareness, the model may not be truly generic, -longitudinal organisation may be too watered down and -limitation of simulated patients, leading to a somewhat reduced enthousiasm towards the end of the preclinical period.

\section{Chapter 2: Factors influencing the effectiveness of communication skills training}

A study is reported, in which students' opinion is sought of the elements of the Maastricht programme they consider to be effective contributions to the development of their communication skills. A questionnaire was administered in two consecutive classes. Using learning effect reported by the students as dependent variable, contributions of various aspects of the programme to the learning effect were analysed. The results show that more than half of the variance in the learning effect was explained by the content of the programme, with only $5 \%$ of the remaining variance being explained by the didactic skills of the teachers. This may be explained by the fact that in this programme it is the students' responsibility to become skilled.

Althougli the questionnaire was administered in such a way that the answers could not be seen by the teachers, student responses may reflect a certain degree of social desirability. Fifty-nine percent of the variance in the learning effect the dependent variable) was explained. A considerable proportion of the variance, i.e. $41 \%$, could not be attributed to these variables. The instrument used in this study relies on students" self-reports. The relation between these self-reports and more objective measures of communication skills is at best unclear.

\section{Chapter 3: Construct validity of MAAS-Global}

An investigation is repotted of the construct validity of an instrument to measure the quality of communication skills, during one curriculum year of a four year longitudinal communication skills training programme in Mastricht. Representative samples consisting of 42 videotapes of students" simulated patient encounters at the beginning of the third year and 35 of the end of the year were assessed by 
nineteen trained obserwers, using the MAAS-Global criteria list. A difference in communication skill competence was found between the performance at the beginning and at the end of the third year. The specific aspects in which the students improved revealed a greater routine in conducting a doctor-patient encounter and a greater structuring capability: those communication skills that have been trained in the years before the study period. Moreover, a significant increase in the percentage of students passing the critical general mark of 5 on a 10-point scale was found. This can be seen as support of the construct validity of the instrument. In giving a general mark at measurement 2 , the raters used the more 'directive' communication skills, such as "structuring" and "consultation evaluation" to make a judgement. Apparently the exploratory skills were taken for granted, and the directive skills provided an extra positive weight in the eyes of the raters. However, the results indicate that this behaviour has not entirely replaced the exploratory approach taught in the earlier years, judging from the $10 \%$ variance that is additionally explained by the item 'empathy' at the second measurement.

\section{Chapter 4: Integrated assessment of commumication skills}

Reliability and validity of a concise global scale to assess communication skills. integrated with clinical procedural stations in an Objective Structured Clinical Examination (OSCE) are studied, and compared to a detailed measurement of communication skills and to the whole OSCE.

A three-item scale, addressing key-elements of doctor-patient communication, was used in the OSCE in the final year of the undergraduate medical training programme of the medical faculty at Maastricht. In every OSCE-station the respectful conduct scale (RCS) was completed by the examiner who also rated the student"s clinical procedural skills. In two OSCE-stations communication skills were also assessed by a separate examiner using a detailed checklist: the MAAS-Global.

Reproducibility of the instruments, their combination and the other stations in the OSCE was estimated and extrapolated to a sample size of minimally acceptable reliability. The RCS was correlated with the MAAS-Global in the same station. The RCS-scores across other stations were correlated to the scores on these other stations and to the MAAS-Global.

Applying the RCS in clinical procedural stations, a generalisability of 0.80 requires 5.75 hours, considerably less than the MAAS-Global by itself or the whole OSCE (13.5 and 9.5 hours, respectively). The combination of the MAAS-Global and $\mathrm{RCS}$-scores reaches a generalisability of 0.80 in 12.5 hours testing time. The RCS correlates 0.71 with the MAAS-Global in the same station. RCS scores across clinical procedural stations show a disattenuated correlation of 0.34 with the scores on the MAAS-Global in communication skills stations. Within stations, the RCS correlates 0.53 with clinical procedural skills performance. 
The RCS is a concise instrument, intended for integrated global assessment of communication skills in all patient encounters in an OSCE. The reproducibility is better than that of the overall OSCE. The instrument does not require additional examiners. It can easily be incorporated into an OSCE, acknowledging the relevance of doctor-patient communication in all patient encounters. However, when used by clinical examiners in stations clinical procedural skills, its scores also reflect the students' performance of these clinical skills.

\section{Chapter 5: Predicting communication skills with a paper-and-pencil test}

An investigation is reported into the value of a written knowledge test of communication skills for predicting scores on a performance test of communication skills. A paper-and-pencil test of knowledge about communication skills (KCS) and a performance test of communication skills in a Multiple Station Examination (MSE) consisting of four stations with standardised patients, were administered to students of years 4 and 6 of the medical schools of Maastricht and Leiden, The Netherlands. Belween the two tests an overall, disattenuated correlation of 0.60 was found $(\mathrm{N}=133, p<0.01)$, suggesting moderate predictive value of the knowledge test for the performance test of communication skills. This correlation is lower than reported correlation between knowledge about clinical procedural skills and the performance of those skills.

The correlation of the KCS and the MSE with measures of students' general medical knowledge or general skills performance is close to zero. This suggests that the KCS and the MSE measure a unique aspect of students' competence, their communication skills. With either instrument more than half of the students" year groups could be correctly classified. This relatively low proportion suggests that communication skills are to a certain extent acquired before students enter medical school. Progress in these skills during medical school can therefore only be limited. Furthermore, the reliabilities of the paper-and-pencil test and the multiple station examination are low in some cases. When the instruments are used to draw conclusions at individual level, greater test lengths will be necessary. The observed correlation between the two instruments is not high. However, if the instruments had. perfect reliability, the correlation would be more substantial.

The correlation is mainly accounted for by students from the medical school at Maastricht and less so in Leiden. This could be attributable to differences in educational format. An integrated approach to teaching, as in the PBL pre-clinical curriculum with a Skillslab at Mastricht might result in a higher correlation between knowledge and performance. In Maastricht communication skills training is organised longitudinally and integrated with other parts of the curriculum.

From this study it may be concluded that the paper and pencil test of knowledge about communication skills has some predictive value for the performance of these 
skills. However, this value is less pronounced than the predictive value of a knowledge test for the performance of clinical procedural skills. Apparently, communication skills follow different rules.

\section{Chapter 6: Longitudinal and concentrated communication skills programmes compared}

The effectiveness of two medical schools" different approaches to communication skills training is assessed. Both schools, in Maastricht and in Leiden have a sixyear undergraduate medical curriculum, divided into four preclinical years and two years of clinical clerkships. The Maastricht problem-based curricultum offers an integrated skills training programme, including communication skills, which runs throughout the first four years. Communication skills training in Leiden is concentrated in courses in the preclinical phase, at the beginning of the clinical phase and preceding two clerkships.

Communication skills of fourth-year and sixth-year students $(\mathrm{N}=161)$ of both universities were assessed in a Multiple Station Examination, using four stations in which students did entire consultations with standardised patients. Trained observers rated these consultations, using a checklist. Maastricht students of both year groups obtained significantly higher checklist scores for their communication skills than their Leiden colleagues. The Leiden students" scores increase between years 4 and 6 , whereas those of the Maastricht students showed no significant change. The higher scores obtained by the Maastricht students indicate a greater overall effectiveness of a longitudinal, integrated approach compared with concentrated courses. Absence of formal training in the clinical phase in Maastricht leads to stabilisation of communication skills, whereas the increase in the Leiden students" scores between years 4 and 6 offers evidence that formal communication skills training during the clinical phase does pay off.

Measured with the MAAS-Global, fourth-year and sixth-year Maastricht students had better communication skills than Leiden students. Assuming that the students are comparable on entering medical school, this difference is likely to be attributable to the curricula they have been exposed to. Maastricht students achieve their maximum score at the end of the fourth year, after having finished their preclinical communication skills training in the Skillslab programme, whereas the scores of the Leiden students gradually increase during years five and six. In Leiden, the clinical phase starts with a gradual introduction and, preceding two clerkships, structured communication skills training takes place in two university leaching weeks. It is therefore likely that the different results are due to this distinction: training results in improved communication skills, no training leads to stabilisation of these skills. In the fourth year the Mastricht students received higher general marks than the Leiden students. No significant difference was found in the general 
marks of the sixth-year students from Maastricht and from Leiden. Leiden sixthyear students may show a comparable general communicative ability but stay behind Maastricht students in the quality of specific skills. A ceiling effect is likely to have occurred for the Maastricht students.

In a PBL curriculum students frequently work together in small groups. They define learning goals and report to each other. This may have a positive influence on their general level of communication. It is not clear whether this influences the specific communication skills that are needed in the doctor-patient encounters studied.

The longitudinal integrated communication skills training programme, embedded in a problem based curriculum seems to be superior to the concentrated programme in a traditional curriculum and formal training during clerkships has a positive effect on the quality of the communication. These findings suggest that the preferred approach to communication skills training would be an integrated, Iongitudinal programme, which continues during the clinical years.

\section{Chapter 7: Development of communication skills in the medical curriculum}

To further compare the effects of a longitudinal and a concentrated communication skills programme 1414 students of all year groups of two medical schools of Maastricht and Leiden, the Netherlands, completed a paper-and-pencil test of knowledge of communication skills. In the two medical schools the same teaching goals hold, and a similar amount of time is devoted to the training of these skills. However, the programming in the curriculum is different. A test of applied knowledge of communication skills, consisting of 78 items in the true-false format, was administered in each class of the two participating medical schools, in a cross-sectional design. The cross-sectional score-patterns per school were compared to the communication skills training programmes. The results on the knowledge about communication skills test are largely a reflection of the training communication skills: the scores mostly increase when there is training and stabilise when there is no training. Maastricht students show the largest improvement during year 1 , and their scores steadily increase in years $1-4$. This is the period in which communication skills training in the Skillslab takes place. They receive no systematic training thereafter, and a stabilisation is seen on the test. In Leiden the students receive communication skills training in years 2 and 3. A sharp rise in scores is found in year 3. In year 4 no training takes place and the scores remain similar. The five-week fulltime introduction to clinical medicine course (ALCO) and a training in the 5th year is reflected in another sharp rise in scores. The 5th year level in Leiden is maintained untill the end of the final year, although another training takes place in this period. There are several possible explanations for this finding. The communication skills addressed in this training, preceding a clerkship, may to be too special- 
ised to be reflected in an increased score on the test, or the test may not be sensitive enough to detect changes in communication skills, brought about by this training. A training effect may also be that the scores do not decline, as has been shown to happen in the absence of training. However, better results than those found in our study are to be expected from more systematic training in the clinical phase. Judging from the findings in this study, the suggestion that training communication skills ought to be concentrated in the clinical years, should rather be interpreted as: training is effective when students meet with patients. This can be in the health care situation, as in the clinical phase of the curriculum, and earlier, with the help of simulated patients.

The final scores of students in both curricula are exactly the same: the programme apparently makes no difference. However, it has been advocated that for a lasting effect, training should be continuous and maximally integrated in the curriculum. Looking at the difference in score patterns between the Maastricht and Leiden students it is likely that communication skills training could further benefit from the best of both worlds. The findings suggest that the optimal training programme of communication skills is longitudinal, integrated skills training as is organised in the Skillslab in Maastricht, followed by a gradual introduction to clinical medicine as organised in the Leiden ALCO programme, and continued training in the clerkships.

\section{Conclusions and discussion}

As a result of the studies reported in this dissertation, we can give a more informed judgement on the benefits and limitations of a communication skills training programme. Overall conclusion of these studies is that, although the communication skills training programme in Maastricht shows many of the characteristics of adequate training programmes, improvement can still be found.

A well-structured communication skills training programme is likely to be successful when it is organised longitudinally, spanning the whole curriculum, maximally embedded in the other parts of the curriculum, with a helical training structure with students alternating between practising amongst each other, via practising with simulated patients, to practising with real patients, on each occasion provided with feedback. A logical consequence is that student-patient encounters must be integrated in this ideal curriculum from the very beginning. A gradual introduction into the clinical phase of the curriculum is a necessary characteristic of this approach, because it will foster continued growth of communication skills throughout the curriculum. Communication skills training in the final phase of the curriculum will benefit most from analysis and elaboration of encounters between students and real patients. 
The helical approach is partly realised in the Maastricht preclinical programme: students practise in exercises and role play as well as with simulated patients. Communication skills are represented in the annual OSCE. However, during the first four years students hardly practise communicating with real patients. The patterns of the development of communication skills differ between Maastricht and Leiden, with Maastricht students showing a more gradual rise in communication proficiency. A more gradual increase in skill performance may lead to better retention of these skills, which would argue in favour of a longitudinal programme that continues throughout the clerkships.

The current model of desired communication skills has been developed in the 1970 's. Society has changed considerably since then. It is unlikely that a medical curriculum will ever be able to specifically prepare students for every situation they will face in the future. It must be an early course objective that students develop their ability to self-analyse. This is a skill that is likely to become as important as adequate communication skills themselves. Flexibility in communication, and self-assessment may therefore represent training areas that are strongly indicated in the current medical curriculum. The instruments that have been studied can assist in acquiring these metacognitive skills.

The fact that students judged the teachers' contribution to their learning effect of lesser importance than their own opportunities to practise may indicate a future for more teacher-independent training aspects. However, students need observations for feedback and analysis of their communicative ability. A high quality communication skills training programme will therefore never be cheap. Judging from the results that good doctor-patient communication can bring about, this is likely to be a small price to pay for a potentially large improvement. 


\section{Samenvatting}

Tn dit proefschrift wordt de vraag behandeld welke factoren in de medische opleiIding de effectiviteit van communicatie vaardigheidstraining beinvloeden. Deze vraag is gespecificeerd in de volgende onderzoeksvragen:

1. Hoe is het communicatie vaardigheidstrainings programma 'op papier' georganiseerd? In hoeverre is deze organisatie gebaseerd op de relevante literatuur?

2. Wat zijn, naar het oordeel van studenten, de belangrijkste curriculum-bijdragen aan hun communicatie vaardigheden?

3. Wat zijn de psychometrische kenmerken van drie typen instrumenten om communicatie vaardigheden te meten (te weten: een gedragsobservatielijst, een beknopte globale scorelijst en een kennis over conmunicatie vaardigheden toets)?

4. Hoe is de ontwikkeling van communicatie vaardigheden van studenten die een longitudinaal versus een geconcentreerd trainingsprogramma volgen?

Hieronder worden de resultaten, per hoofdstuk, samengevat.

\section{Hoofdstuk 1: Onderwijs en toetsing van communicatie vaardigheden in Maastricht}

Dit hoofdstuk biedt een achtergrond voor cle lezers die dit programma niet kennen. Relevante literatuur over de inwloed van goede en slechte communicatie wordı besproken. De fases in de ontwikkeling van het communicatie vaardigheden programma in het preklinische curriculum van het Skillslab van de medische faculteit van de Universiteit Maastricht wordt beschreven. Een multidisciplinaire werkgroep heeft onderwijsdoelen voor communicatie vaardigheden ontwikkeld. Uitgangspunt daarbij was dat het onderwijs moest worden gericht op observeerbar gedrag dat de student moest vertonen. Deze onderwijsdoelen werden geintegreerd tot een generiek model voor de communicatie tussen arts en patiënt. Vervolgens werd een longitudinaal trainingsprogramma gemaakt, dat de vier jaar van het preklinische curriculum besloeg. Bij het ontwikkelen van dit programma werden de volgende stadia doorlopen: eerst werd onderwijsmateriaal gemaakt, daarna een toetsinstrument en programma evaluatie instrumenten. Programma evaluatie maakte het mogelijk de student-oordelen terug te rapporteren aan de docenten, hun vakgroepen en aan de onderwijsorganisatie. Tenslotte werd docententraining geprofessionaliseerd. 
Het beschreven programma is organisatorisch stevig verankerd in de infrastructuur van het Skillslab. Niettemin hebben we nog flink wat problemen. De volgende zijn behandeld: - de moeilijkheid goede rollen en situaties te simuleren waarmee eerstejaars studenten kunnen oefenen, -gedrag als invalshoek bij de trainingen leidt ertoe dat er minder aandacht is voor bewustwording van de eigen attitude, -mogelijk is het model niet helemaal generiek, -de longitudinale organisatie, waarbij studenten vier jaar lang eens per twee weken een bijeenkomst hebben, is wellicht te zeer 'verdund', en -de beperkingen van simulatiepatiënten, die ertoe leiden dat vierdejaars studenten uitgekeken raken op deze onderwijsvorm.

\section{Hoofdstuk 2: Factoren die van invloed zijn op de effectiviteit van communicatie vaardigheidstraining}

Een onderzoek wordt gerapporteerd waarin studenten is gevraagd welke onderdelen van het Maastrichtse programma bijdragen aan de ontwikkeling van hun communicatie vaardigheden. Een vragenlijst is in twee opeenvolgende curriculumjaren ingevuld. De bijdrage van verschillende programma-onderdelen aan het leereffect werd geanalyseerd. De resultaten wijzen erop dat meer dan de helft van de variantie in het leereffect verklaard wordt door de inhoud van het programma, terwijl slechts vijf procent van de resterende variantie kon worden toegeschreven aan de didactische vaardigheden van de docenten. Deze bevinding wordt wellicht verklaard uit het feit dat de verantwoordelijkheid voor het leren in dit programma in hoofdzaak bij de student ligt.

Hoewel de vragenlijst zo werd gebruikt dat de docenten de antwoorden niet konden zien, kunnen de antwoorden van de studenten beïnvloed zijn door sociale wenselijkheid. Négenenvijftig procent van de variantie in het leereffect (de afhankelijke variabele) kon worden verklaard. Een aanzienlijke rest van eenenveertig procent kon niet worden toegeschreven aan de onderzochte variabelen. Het instrument dat voor dit onderzoek gebruikt is vroeg naar de indrukken van studenten zelf. De relatie tussen deze rapportages over zichzelf en objectievere maten van communicatie vaardigheden is op zijn best onduidelijk.

\section{Hoofdstuk 3: Begripsvaliditeit van de MAAS-Globaal}

Een onderzoek wordt beschreven naar de begripsvaliditeit van een instrument om communicatie vaardigheden te meten. Representatieve steekproeven van respectievelijk 42 banden van het eerste, en 35 banden van het laatste simulatiepatiënt contact van studenten uit het derde studiejaar van de medische faculteit van de Universiteit Maastricht zijn beoordeeld door negentien getrainde observatoren, met de MAAS-Globaal criterialijst. $\mathrm{Zij}$ vonden een verschil in communicatie vaardigheden tussen het eerste en het laatste simulatiepatiënt contact van het derde jaar. De studenten waren beter in het gemak waarmee ze een arts-patiënt contact voerden en de 
mate warin ze dat contact structureerden: die communicatie waardigheden die in voorafgaande jaren getraind waren. Bovendien had een significant grotere groep studenten een 'voldoende' gehaald aan het eind van het jaar. Dit kan beschouwd worden als steun voor de begripsvaliditeit van het instrument.

Bij het geven van een rapportciffer hebben de observatoren zich bij de tweede meting vooral gebaseend op de meer 'directieve' communicatie vaardigheden, zoals "structureren", en "consult evalueren". Blijkbaar werden de meer exploratieve vaurdigheden vanzelfsprekend gevonden en gaven de directieve vaardigheden een extra positieve bijdrage aan het oordeel van de observatoren. Uit de resultaten blijkt bovendien dat dit directieve gedrag niet geheel in de plaats is gekomen van de exploratieve benadering die vooral in de eerste jaren is angeleerd, te oordelen nar de $10 \%$ variantie die additioneel verklaard wordt door het item "empathie" bij de tweede meting.

\section{Hoofdstuk 4: Geïntegreerde meting van communicatie vaardigheden}

De betrouwbaarheid en validiteit van een beknopte globale beoordelingslijst voor communicatie vaardigheden zijn onderzocht, in vergelijking met een gedatailleerde meting van communicatie en met een hele vaardigheidstoets.

Een lijst van drie items, sleutelbegrippen van arts-patiënt communicatie, is in de zesdejaars vaardigheidstoets van de medische faculteit in Maastricht gebruikt. In elk vaardigheidstoetsstation is deze respectvolle bejegeningschaal (RBS) ingevuld door de observator die ook de lichamelijk onderzoeksvaardigheden van de student beoordeelde. In twee vaardigheidstoetsstations zijn de communicatie vaardigheden ook door een aparte beoordelaar gemeten met een meer gedetailleerde scorelijst ${ }_{\text {de }}$ MAAS-GIobaal.

Een schatting is gemaakt van de reproduceerbaarheid van elk van deze instrumenten, van hun combinatie en van de andere stations in de toets. Deze reproduceerbaarheidscoefficient is geexxtrapoleerd naar de toetsdur die nodig is om een minimaal acceptabele betrouwbarheid te verkrigen. De RBS is gecorfelerd met de MAAS-Globaal in hetzelfde station. De RBS-scores van alle andere toetsstations zijn gecorreleerd met de scores van deze toetsstations en met de MAS-Globaal.

Als de RBS in lichamelijk onderzoeksstations wordt toegepast is 5,75 uur toetstijd nodig om een generaliseerbaarheid van 0,80 te bereiken. Dit is veel korter dan de MAAS-Globaal alleen, of zelfs dan de gehele vardigheidstoets (respectievelijk 13,5 uur en 9,5 uur). Met de combinatie van de MAAS-Globaal en de RBS-scores zou een toets van 12,5 uur nodig zijn om een generaliseerbaarheid van 0,80 te bereiken. De correlatie tussen de RBS en de MAAS-Globaal in hetzelfde station is 0,71. De correlatie tussen de gezamenlijke RBS-scores wan de andere stations en de MAAS-Global in de communicatie stations is 0,34 (gecorrigeerd voor attenuatie). Bimen stations is de correlatie tussen de RBS en de score voor de lichamelijk onderzoek vaardigheid 0,53 . 
De RBS is een beknopte globale schaal, bedoeld om communicatie vaardigheden geintegreerd te meten in alle contacten met patiénten in vaardigheidstoetsstations. De reproduceerbaarheid is beter dan die van de gehele vaardigheidstoets. Extra observatoren zijn hierbij niet ingezet. Het instrument kan gemakkelijk worden toegevoegd aan vardigheidstoetsstations, waardoor het belang wan communicatie vaardigheden angegeven wordt. Wanneer observatoren van klinische disciplines de lijst gebruiken in een toetsstation warin lichamelijk onderzoek vaardigheden getoetst worden weerspiegelt de RBS-score tevens de kwaliteit van dat lichamelijk onderzoek.

\section{Hoofdstuk 5: Communicatie vaardigheden voorspellen met een schriftelijke toets}

Hier wordt verslag gedaan van een onderzoek naar de waarde van een toets van kennis over communicatie vaardigheden om de score op een gedragstoets te voorspellen. Een schriftelijke toets van kennis over communicatie vaardigheden en een gedragsmeting van communicatie vaardigheden in cen stationstoets van vier stations met gestandaardiseerde patiënten zijn afgenomen aan studenten van het vierde en het zesde, studiejaar van de medische faculteiten van Maastricht en Leiden. De correlatie tussen beide toetsen bedroeg $0,60(N=133, p<0,01$; gecorrigeerd voor attenuatie). Dit suggereert een bescheiden predictieve waarde van de kennistoets voor de gedragstoets van communicatie vaardigheden. De gevonden correlatie is lager dan die tussen kennis over lichamelijk onderzoeksvaardigheden en de daadwerkelijke beheersing van die vaardigheden.

De correlatie tussen de kennistoets en gedragsmeting van comnunicatie vaardigheden enerzijds en toetsresultaten van algemeen medische kennis of algemene vaardigheidsbeheersing anderzijds is bijna nul. Dit wijst erop dat zowel de kennistoets als de gedragsmeting een uniek deel van de competentie van studenten meten: hun communicatie vaardigheden. Uit de scores van elk van de instrumenten kon van ongeveer de helft van de deelnemende studenten de jaargroep herleid worden. Dit relatief kleine deel komt wellicht doordat communicatie vaardigheden tot op zekere hoogte worden verworven voordat studenten de medische opleiding beginnen. Daardoor kan er slechts beperkte groei in die vaardigheden plaatsvinden. Bovendien zijn de betrouwbarheden van de kennistoets en van de gedragstoetsing in sommige gevallen laag. Als deze instrumenten gebruikt zouden worden om beslissingen over individuen te nemen is een langere toets nodig. De waargenomen correlatie tussen de twee instrumenten is niet hoog. Als deze echter gecorrigeerd wordt voor de ruis die door de onvolmaakte betrouwbaarheid veroorzaakt wordt bijkt de ware correlatie beduidend hoger te zijn.

Een hoge correlatie wordt hoofdzakelijk gevonden bij de studenten uit Maastricht; minder bij de Leidse studenten. Dit verschil kan toegeschreven worden aan verschillen in het onderwijs. Een geintegreerd onderwijsaanbod, zoals in het pro- 
bleem-gestuurde preklinische curriculum, met een Skillslab zoals in Maastricht, leidt waarschijnlijk tot een grote samenhang tussen kennis en vaardigheden. In Maastricht is de communicatie vaardigheidstraining longitudinaal georganiseerd, geïntegreerd met andere curriculum onderdelen.

Uit dit onderzoek kunnen we concluderen dat een schriftelijke toets van kennis over communicatie vaardigheden enige predictieve waarde heeft voor de uitoefening van die vaardigheden. Deze is echter minder groot dan de predictieve waarde van een kennistoets voor de uitoefening van lichamelijk onderzoek vaardigheden. Klaarblijkelijk gelden voor communicatie vaardigheden andere regels.

\section{Hoofdstuk 6: Een vergelijking tussen een longitudinaal en een geconcentreerd communicatie vardigheidstrainings- programma}

De effectiviteit van de trainingsprogramma's communicatie vaardigheden in twee medische faculteiten is gemeten. In beide faculteiten duut het basis-curriculum zes jaar, verdeeld in vier jaar preklinisch en twee jaar klinisch onderwijs in coassistentschappen. Het Maastrichtse probleemgestuurde curriculum omvat een vier jaar durend, geïntegreerd vaardigheidstrainingsprogramma, waarvan communicatie vaardigheden deel uitmaken. In Leiden worden communicatie vaardigheidstrainingen in geconcentreerde cursussen aangeboden in de preklinische fase, aan het begin van de klinische fase en voorafgaande aan lwee co-schapppen.

De communicatie vaardigheden van 161 vierde- en zesdejaars studenten van beide faculteiten werden gemeten in een toets met vier stations, waarin ze hele consulten met gestandaardiseerde patiënten voerden. Getrainde observatoren beoordeelden deze consulten met een criterialijst. De vierde- en zesdejaars studenten uit Maastricht behaalden significant hogere scores op deze criterialijst dan hun Leidse col.lega"s. De scores van de studenten uit Leiden namen toe tussen het vierde en het zesde jaar, terwijl die uit Maastricht niet significant veranderden. De hogere scores van de Maastrichtse studenten wijzen op cen grotere effectiviteit van de longitudinale, geintegreerde aanpak, vergeleken met het geconcentreerde programma. In Maastricht is geen systematische communicatie vaardigheidstraining tijdens de klinische fase, en blijven de resultaten dezelfde. De toename in score tussen jaar vier en zes, van de Leidse studenten, toont aan dat systematische training gedurende de klinische fase effect heeft.

Gemeten met de MAAS-Globaal hadden de Maastrichtse vierde- en zesdejaars studenten betere communicatie vaardigheden dan hun Leidse collega's. Ervan uitgaande dat de studenten vergelijkbaar zijn bij aanvang van de studie is dit verschil toe te schrijven aan het verschil in curriculum dat zij gevolgd hebben. De Maastrichtse studenten behalen de hoogste score aan het einde van het vierde jaar, nadat zij hun preklinische communicatie vaardigheidstrainingsprogramma in het Skillslab hebben voltooid, terwijl de scores van de Leidse studenten gelleidelijk toene- 
men gedurende het vijfde en zesde studiejaar. In Leiden begint de klinische fase met een introductie in het ALCO-schap en wordt in de klinische fase systematisch getraind. Het is daarom waarschijnlijk dat de verschillen in resultaten daardoor veroorzaakt worden: training resulteert in grotere vaardigheid, en ophouden met training leidt tot stabilisatie van deze vaardigheden.

In het vierde jaar krijgen de Maastrichtse studenten hogere rapportcijfers voor communicatie dan hun Leidse collega's. Aan het eind van het zesde jaar was dit verschil verdwenen. De zesdejaars studenten uit Leiden geven een vergelijkbare algemene indruk maar blijven achter als naar de kwaliteit van specifieke vaardigheden gekeken wordt. Het mogelijk dat de Maastrichtse studenten het maximaal haalbare op het meetinstrument bereikt hadden ('plafond-effect').

In probleemgestuurd onderwijs werken studenten vaak samen in kleine groepen. $\mathrm{Ze}$ formuleren leerdoelen en rapporteren aan elkaar. Dit zou hun algemene niveau van communiceren positief kunnen beïnvloeden. Het is niet bekend of dit ook van invloed is op de specifieke communicatie vaardigheden die van belang zijn in het hulpverleningsgesprek tussen arts en patiënt.

Het longitudinale, geïntegreerde communicatie vaardigheidstrainingsprogramma, ingebed in een probleemgestuurd curriculum lijkt beter te werken dan het geconcentreerde programma in een traditioneel curriculum. Systematische training gedurende de co-assistentschappen hebben een positief effect op de kwaliteit van de communicatie. Op grond van deze bevindingen lijkt het optimale trainingsprogramma communicatie vaardigheden te bestaan uit een geïntegreerd, longitudinaal progranma dat voortgezet wordt in de klinische fase.

\section{Hoofdstuk 7: Ontwikkeling van communicatie vaardigheden in het medische curriculum}

In een onderzoek naar de effecten van een longitudinaal en een geconcentreerd communicatie vaardigheidstrainingsprogramma hebben 1414 studenten van alle jaargroepen van de medische faculteiten in Maastricht en in Leiden een schriftelijke toets van kennis over vaardigheden gemaakt. De twee medische faculteiten onderschrijven dezelfde onderwijsdoelen voor communicatie vaardigheden en er wordt ongeveer evenveel tijd aan training en oefenen besteed. De manier waarop de trainingen georganiseerd zijn verschilt echter.

Een toets van toegepaste kennis over communicatie vaardigheden, bestaande uit 78 juist-onjuist vragen is door studenten van elke jaargang van de twee medische faculteiten gemaakt. De onderzoeksopzet was dus een dwarsdoorsnede van alle jaargangen. Deze resultaten per school werden vergeleken met de communicatie vaardigheidstrainingen. De resultaten op de kennis over communicatie vaardigheden toets zijn goeddeels cen afspiegeling van de trainingen: de scores gaan in het algemeen "omhoog" als er getraind is en "stabiliseren" als er geen training is. De studenten in Maastricht leren het meeste in het eerste jaar en hun scores nemen geleidelijk toe gedurende de jaren 1 tot 4 . Dit is ook de periode waarin training in 
delijk toe gedurende de jaren 1 tot 4. Dit is ook de periode waarin training in het Skillslab plaatsvindt. Daarna wordt niet systematisch getraind en de toetsresultaten blijven gelijk. De studenten uit Leiden krijgen training in de jaren 2 en 3 . In jaar 3 nemen de scores sterk toe. In het vierde jaar wordt niet getraind en blijven de scores gelijk. Het vijfweekse, voltijdse ALCO-schap en een training in het vijfde jaar worden weergegeven in een sterke toename van de score. Het vijfdejaars niveau in Leiden blijft gehandhaafd, ondanks dat er nog een training plaatsvindt in die periode. Deze bevinding kan op een aantal manieren verklaard worden. De communicatie vaardigheden die in die fase aan de orde komen zouden zo specifiek kunnen zijn dat ze niet in een hogere score op de toets tot uiting komen, of de toets is niet specifiek genoeg om de effecten van deze training te registreren. Een effect van de training kan ook zijn dat de scores niet naar beneden gaan, zoals gebeurt wanneer er niet getraind wordt. Niettemin zou er meer trainingseffect te verwachten zijn in de klinische fase. Afgaande op de resultaten in deze studie moet de aanbeveling: training is pas effectief in de klinische fase, opgevat worden als: training is effectief als studenten patiënten zien. Dit kan plaatsvinden in de gezondheidszorg praktijk, maar ook daarbuiten met het inzetten van simulatiepatiënten.

De zesdejaars scores op de kennis over communicatie vaardigheden toets zijn precies gelijk in beide curricula. Het lijkt erop alsof het programma geen verschil maakt. Het is echter bekend dat training effectiever is naarmate deze meer continu en geintegreerd in het curriculum wordt aangeboden. Te oordelen naar de scorepatronen van de studenten uit Maastricht en uit Leiden is het waarschijnlijk dat training effectiever wordt als geprofiteerd wordt van het beste van beide programma's. De bevindingen suggereren dat het optimale trainingsprogramma voor communicatie vaardigheden bestaat uit longitudinale geüntegreerde training zoals georganiseerd in het Skillslab in Maastricht, gevolgd door een geleidelijke introductie in de klinische fase zoals georganiseerd in hel ALCO-schap in Leiden, en voortgezet gedurende de co-assistentschappen.

\section{Conclusies en discussie}

Door de onderzoeken die in dit proefschrift beschreven zijn kunnen we een beter onderbouwd oordeel geven over de voordelen en beperkingen van een communicatie vaardigheidstrainingsprogramma. De samenvattende conclusie uit deze onderzoeken is dat, hoewel het trainingsprogramma in Maastricht aan veel criteria van een goed trainingsprogramma voldoet, er zeker nog onderdelen zijn die beter kunnen. Een gestructureerd communicatie vaardigheidstrainingsprogramma zall effectief zijn als het longitudinaal georganiseerd is, parallel aan het gehele curriculum en maximaal ingebed in overige delen van het curriculum. Daarbij moet steeds geoefend worden, met elkaar, met simulatie patiënten en met patiënten, terwijl studenten steeds commentaar kunnen vragen en krijgen. Een logisch gevolg daarvan 
is dat studenten in elke fase van de opleiding met patiënten moeten kunnen oefenen. Een geleidelijke introductie in de klinische fase is op die manier ook te realiseren. Dit zal leiden tot vooruitgang in communicatie vaardigheden gedurende het hele curriculum. Communicatie vaardigheidstraining in de laatste fase van het basiscurriculum zal het meeste baat hebben van analyse en bespreking van contacten tussen studenten en echte patiënten.

Deze afwisseling van oefenmogelijkheden is ten dele verwezenlijkt in het Maastrichtse preklinische programma: studenten krijgen oefeningen, doen rollenspellen en oefenen met simulatiepatiënten. Communicatie vaardigheden zijn onderdeel van de jaarlijkse vaardigheidstoets. Tijdens de eerste vier jaar oefenen studenten hun communicatie echter nauwelijks met echte patiënten.

De ontwikkeling van communicatie vaardigheden in Maastricht en in Leiden is uiteenlopend. Studenten uit Maastricht vertonen een geleidelijker toename. Het is waarschijnlijk dat een geleidelijker opbouw van deze vaardigheden ertoe leidt dat ze dan ook beter beklijven. Ook dit is een pleidooi voor het continueren van training in de klinische fase.

Het huidige model voor communicatie vaardigheden is ontwikkeld rond 1970. De maatschappij heeft sinds die tijd ook flinke ontwikkelingen doorgemaakt. Het is onwaarsćhijnlijk dat het medische curriculum haar studenten kan voorbereiden op elke situatie die ze kunnen tegenkomen. Het moet daarom, vanaf het begin van het curriculum een onderwijsdoel zijn dat studenten leren zichzelf adequaat te beoordelen. Deze vaardigheid is waarschijnlijk net zo belangrijk als goede communicatie op zich. Flexibiliteit in de bejegening, en zelfbeoordeling zijn daardoor onderdelen die in het huidige medische curriculum niet meer mogen ontbreken. De meetinstrumenten warover in dit proefschrift verslag wordt gedaan kunnen eraan bijdragen dat deze metacognitieve vaardigheden verworven worden. Het feit dat studenten zelf aangeven meer te leren van de oefenmogelijkheden dan van de docenten geeft wellicht uitzicht op meer docent-onafhankelijke trainingsonderdelen. Obserwaties blijven echter nodig teneinde te leren te analyseren en becommentarièren. Een goed communicatie vaardigheidstrainingsprogramma zal daatom nooit goedkoop worden. Met het oog op de effecten van goede communicatie is dit waarschijnlijk een kleine investering voor een grote verbetering. 


\section{Curriculum vitae}

Tan van Dalen was born in Eindhoven, The Netherlands, on 27 October, 1951. After finishing Secondary School (HBS-B) there, in 1970, he studied psychology at the Free University of Amsterdam, where he graduated in 1978 as a clinical psychologist. As a student he had several teaching jobs, which made him realise that he preferred teaching to full-time health care.

In November 1978 he joined the Skillslab, Faculty of Medicine, University of Maastricht, to develop a communication skills training programme. From 19801985 he designed and set up the communication skills curriculum of the new Faculty of Health Sciences at Maastricht University. Since 1985 he has worked exclusively for the Faculty of Medicine. His responsibilities include the coordination of the undergraduate communication skills teaching and assessment programme. Aside from performing various teaching roles in the Faculty of Medicine, he is an international consultant for the implementation of skills training facilities. He has published about medical education and communication skills teaching. He has coauthored four books on communication skills for the health professions and is Associate Editor of Education for Health, Change in Learning and Practice. 